FERNANDA YAMAMOTO RICARDO DA SILVA

\title{
AVALIAÇÃO DA RESPOSTA INFLAMATÓRIA LOCAL APÓS ISQUEMIA E REPERFUSÃO INTESTINAL EM RATOS: EFEITO DO TRATAMENTO COM ESTRADIOL
}

Dissertação apresentada ao Programa de Pós-Graduação em Farmacologia do Instituto de Ciências Biomédicas da Universidade de São Paulo, para obtenção do Título de Mestre em Ciências. 


\section{AVALIAÇÃO DA RESPOSTA INFLAMATÓRIA LOCAL APÓS ISQUEMIA E REPERFUSÃO INTESTINAL EM RATOS: EFEITO DO TRATAMENTO COM ESTRADIOL}

Dissertação apresentada ao Programa de Pós-Graduação do Instituto de Ciências Biomédicas da Universidade de São Paulo, para obtenção do Título de Mestre em Ciências.

Área de Concentração: Farmacologia

Orientador: Prof. Dr. Wothan Tavares de Lima

Versão corrigida. A versão original eletrônica encontrase disponível tanto na Biblioteca do ICB quanto na Biblioteca Digital de Teses e Dissertações da USP (BDTD). 
DADOS DE CATALOGAÇÃO NA PUBLICAÇÄO (CIP)

Serviço de Biblioteca e Informaģäo Biomédica do

Instituto de Cièncias Biomédicas da Universidade de Säo Paulo

reprodug̣ă năo autorizada pelo autor

Silva. Fernanda Yamamoto Ricardø da.

Avaliação da resposta inflamatória local após isquemia e reperfusäo intestinal em ratos: efeito do tratamento com estradiol $/$ Fernanda Yamamoto Ricardo da Silva. - 5.30 Paulo, 2015.

Orientador. Prof. Dr. Wothan Tavares de Lima.

Dissertaçäo (Mestrado) - Universidade de Säo Paulo, Instituto de Ciências Biomédicas. Departamento de Farmacologia. Área de concentraqäo: Farmacologia. Linha de pesquisa: Fisiopatologia da inflamaçä̉o experimental.

Versäo do título para o inglës: Local inflammatory response following intestinal ischemia and reperfusion in male rats: effects of estradiol treatment effect.

1. Inflamação 2 Isquemia e reperfusäo intestinal 3. Estradiol 4. Ratos I. Lima, Prof. Dr. Wothan Tavares de II. Universidade de São Paulo. Instituto de Ciencias Biomédicas. Programa de Pós-Graduaçäo em Farmacologia III. Titulo. 
Candidato(a):

Título da Dissertação:

Orientador(a):

\section{Fernanda Yamamoto Ricardo da Silva.}

Avaliação da resposta inflamatória local após isquemia e reperfusäo intestinal em ratos: efeito do tratamento com estradiol.

Prof. Dr. Wothan Tavares de Lima.

A Comissão Julgadora dos trabalhos de Defesa da Dissertaçäo de Mestrado, em sessão pủblica realizada a I. considerou

( ) Aprovado(a)

( ) Reprovado(a)

\begin{abstract}
Examinador(a):
\end{abstract}
Assinatura:

Nome:

Instituição:

Examinador(a): Assinatura:

Nome:

Instituição:

Presidente: Assinatura:

Nome:

Instituiçảa: 


\section{Certificado}

Certificamos que o protocolo registrado sob $n^{\circ} 111$ nas fls. 10 do livro 03 para uso de animais em experimentação, sob a responsabilidade do Prof(a) Dr(a)) Wothan Tavares de Lima, Coordenador (a) da Linha de pesquisa "Estudo da influência do gênero na contratilidade, microcirculaçâo e geraçâo de mediadores inflamatórios no intestino após a isquemia e reperfusão: Envolvimento do sistema linfático e de possíveis vias de sinalização" do qual participam o(s) aluno(s) Evelyn Thais Fantozzi, Fernanda Yamamoto Ricardo da Silva, Maria Beatriz Bernadez Amorin, estagiários Sara Garbin, Guilherme Henrique Gatti e os pesquisadores Bernardo Boris Vargaftig, Ricardo Martins de Oliveira Filho, Ana Cristina Breithaupt-Faloppa, está de acordo com os Princípios Éticos de Experimentação Animal adotado pela Sociedade Brasileira de Ciência de Animais de Laboratório (SBCAL) e foi aprovado pela COMISSÃO DE ÉTICA NO USO DE ANIMAIS (CEUA) em 04.11.2013, com validade de 4 anos.

São Paulo, 06 de novembro de 2013.

P) Ëcules

Prof. Dr. ANDEERSON DE SÁ NUNES Vice-Coordenador-CEUA- ICB/USP

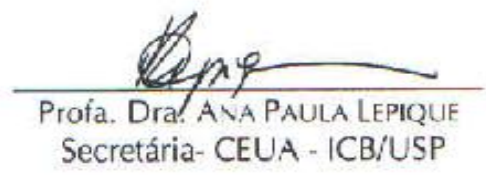


A minha família por todo apoio e dedicação durante toda a minha jornada, que mesmo sem perceber estão sempre me incentivando e ajudando.

Obrigada! 


\section{AGRADECIMENTOS}

Aos meus pais, Ana e Carmo, pelo apoio incondicional nas horas difíceis. Sem vocês não teria chegado até esse momento, obrigada por todo o amor, carinho, incentivo e compreensão!

A minha família, em especial aos meus irmãos, Marcela e Felipe, por todos os anos juntos de brigas e alegrias, sem vocês crescer teria sido muito mais sem graça. Além dos meus bichos de estimação, pelas fofuras, loucuras e momentos de pausa quando tudo parecia não fazer mais sentido.

Ao meu namorado, Rafael, que de forma especial e carinhosa me deu apoio durante as fases difíceis da minha jornada.

Ao meu orientador, Wothan, pelo suporte durante estes anos de estudo e crescimento científico. Assim como pelas correções, incentivos e ensinamentos.

A Ana Cristina, pelos conselhos e soluções. Agradeço imensamente pela ajuda dispendida para a realização desse trabalho.

As minhas parceiras de laboratório, Evelyn, Sara, Maria Beatriz e Bárbara, obrigada pelas risadas, longas noites, amizade, apoio e companheirismo. Também as minhas amigas de longa data, que começaram no colégio ou mesmo durante a graduação.

À USP e ao Laboratório de Fisiopatologia da Inflamação Experimental do Instituto de Ciências Biomédicas. Em especial às técnicas, Helory e Cida, e igualmente ao professor Ricardo, agradeço imensamente pelo apoio, auxílio e convivência.

Ao CAPES e a FAPESP pelo apoio financeiro.

A todos que de alguma maneira foram importantes e fundamentais para a execução desse trabalho. 


\section{RESUMO}

\section{RICARDO-DA-SILVA, F.Y. Avaliação da resposta inflamatória local após isquemia e reperfusão intestinal em ratos: efeito do tratamento com estradiol. $2015.130 \mathrm{f}$.}

Dissertação (Mestrado Farmacologia) - Instituto de Ciências Biomédicas, Universidade de São Paulo, São Paulo, 2015.

A isquemia e reperfusão (IR) intestinal pode causar inflamação local e sistêmica. Evidências experimentais mostram que fêmeas são mais resistentes aos efeitos inflamatórios da IR, possivelmente em decorrência dos efeitos protetores o estradiol. Todavia, o papel do estradiol no controle da inflamação causada pela IR intestinal em machos ainda não foi totalmente elucidado. Para investigar a modulação da inflamação gerada no intestino e suas repercussões sistêmicas utilizamos grupos de ratos (Wistar, 60 dias, $160 \mathrm{~g}$ ) submetidos a IR intestinal. Após a anestesia a isquemia intestinal foi realizada pela obstrução do fluxo da artéria mesentérica superior (AMS) durante 45 min utilizando um clipe cirúrgico. O retorno do fluxo da AMS (reperfusão intestinal) ocorreu removendo-se o clipe cirúrgico. Decorridas $2 \mathrm{~h}$ de reperfusão intestinal os animais foram submetidos à eutanásia e os experimentos conduzidos. O tratamento dos animais com estradiol $(280 \mu \mathrm{g} / \mathrm{kg})$ se deu em dois protocolos: um considerado terapêutico onde os animais receberam dose (i. v.) única do hormônio $30 \mathrm{~min}$ após a indução da isquemia intestinal (E30) e no outro classificado como preventivo, os animais receberam dose única (s. c.) do hormônio 24 h antes da indução da isquemia (E24). Como controle utilizamos ratos falsamente submetidos à isquemia (Sham) e animais não manipulados (Basal). Os estudos quantificaram a permeabilidade vascular e da mucosa intestinal (extravasamento do corante azul de Evans e de dextran-FITC respectivamente), o recrutamento/ativação de neutrófilos (atividade de mieloperoxidase), motilidade e reatividade ex vivo do íleo (trânsito de carvão ativado no intestino e curva dose resposta à metacolina, respectivamente). Paralelamente, isolamos o intestino numa embalagem plástica quantificamos o volume de fluido gerado pelo intestino durante o período de IR intestinal e nele determinamos a concentração de IL-10, TNF- $\alpha$, leucócitos e corante azul de Evans. Para investigar as repercussões sistêmicas da IR intestinal, determinamos o número de leucócitos circulantes, células da medula óssea, marcadores de lesão tecidual (fosfatase alcalina e lactato desidrogenase (LDH)) e citocinas (IL-1 $\beta$, IL-6, IL12p70, IL-17, IL-10, IFN- $\gamma$ ), fatores (VEGF, TNF- $\alpha$ e GM-CSF) e quimiocinas (MIP-1 $\alpha$, MCP-1, GRO/KC e IP-10) presentes no 
soro dos animais. Estudos in vitro sobre a capacidade de migração de neutrófilos também foram conduzidos. De maneira geral nossos resultados mostraram que a IR intestinal aumentou a permeabilidade vascular e da mucosa intestinal, o recrutamento/ativação de neutrófilos e diminuiu a motilidade e reatividade ex vivo frente a metacolina. Ainda, o volume de fluido intestinal exsudado reduziu, mas nele houve aumento de TNF- $\alpha$ e IL-10 e de leucócitos. Sistemicamente a IR intestinal elevou o número de leucócitos circulantes (granulócitos), e diminuiu o de células da medula óssea. Aumentou também os níveis de fosfatase alcalina e LDH no soro, bem como a concentração de todas as citocinas, fatores e quimiocinas dosados. Ainda, neutrófilos revelaram aumento da migração em ensaio in vitro. Em relação aos protocolos de tratamento dos animais com estradiol, nossos dados mostraram que em ambos (E30 e E24) houve redução de TNF- $\alpha$ e de leucócitos no fluido intestinal, recrutamento/ativação de neutrófilos, LDH e de IL-1 $\beta$, IL-10, VEGF, MIP-1 $\alpha$, MCP-1, GRO/KC e IP-10. Apenas o tratamento preventivo (E24) causou redução da permeabilidade vascular intestinal, aumento da motilidade intestinal e a contagem de células da medula óssea. Por outro lado, o tratamento terapêutico (E30) causou diminuição da permeabilidade da mucosa intestinal, leucócitos circulantes, fosfatase alcalina e de IL-6, TNF- $\alpha$ e GM-CSF no soro dos animais.

Tomados em conjunto os resultados apresentados neste estudo sugerem que as repercussões locais e sistêmicas decorrentes da IR intestinal podem ser atenuadas pelo estradiol no contexto de um efeito terapêutico ou preventivo. Visto que a inflamação no intestino ao ser disseminada, acarreta graves consequências sistêmicas, nossos dados permitem inferir que o estradiol seja uma alternativa farmacológica de interesse no controle e compreensão dos mecanismos subjacentes à indução da inflamação intestinal após eventos isquêmicos seguidos de reperfusão intestinal.

Palavras-chave: Inflamação. Isquemia e Reperfusão Intestinal. Estradiol. Ratos. 


\begin{abstract}
RICARDO-DA-SILVA, F.Y. Local inflammatory response following intestinal ischemia and reperfusion in male rats: effect of estradiol treatment effect. 2015. 130 p. Masters thesis (Pharmacology) - Instituto de Ciências Biomédicas, Universidade de São Paulo, São Paulo, 2015.
\end{abstract}

Intestinal ischemia/reperfusion (IR) causes local and remote injuries. Experimental evidence indicates that female rats are more resistant to IR inflammatory effects and this could likely be due the protective effects of estradiol. However, the role of estradiol on the control of inflammation induced by by intestinal IR in male, is still not completely elucidated. In order to investigate the inflammatory response in the intestine and its systemic repercussions, groups of male rats (Wistar, 60 days, $160 \mathrm{~g}$ ) were submitted to intestinal IR. Under anesthesia, intestinal ischemia was induced by obstruction of superior mesenteric artery (SMA) during $45 \mathrm{~min}$. After $2 \mathrm{~h}$ of intestinal reperfusion the animals were submitted to euthanasia and the experiments were conducted. Groups of animals received estradiol treatment $(280 \mu \mathrm{g} / \mathrm{kg}) 30 \mathrm{~min}$ after the induction of intestinal ischemia (E30) (therapeutic treatment) or (preventive treatment) $24 \mathrm{~h}$ before the induction of intestinal ischemia (E24). As controls rats were falsely submitted to instestinal IR (Sham) and as reference we used non manipulated rats (Naïve). Vascular and mucosal permeability from intestine were quantified by Evans blue dye and dextran-FITC extravasation, respectively. The recruitment/activation of neutrophils was determined by myeloperoxidase activity, the intestinal motility and ileum ex vivo reactivity by activated coal transit in the intestine and by dose response curve to methacholine, respectively) were also evaluated. In a parallel set of experiments, the intestine of rats submitted to intestinal IR or sham was isolated in a plastic bag and the volume and content of the fluid accumulated inside during intestinal IR period were analyzed. The levels of IL-10, TNF- $\alpha$, leukocytes and Evans blue dye extravaseted were quantified. In order to investigate the systemic repercussions of intestinal IR, we determined the number of blood leukocytes, bone marrow cells, tissue injury markers (alkaline phosphatase and lactate dehydrogenase (LDH)), cytokines (IL-1 $\beta$, IL-6, IL12p70, IL-17, IL-10,IFN- $\gamma$ ), factors (VEGF, TNF- $\alpha$ e GM-CSF) and chemokines (MIP-1 $\alpha$, MCP-1, GRO/KC e IP-10) in serum of those animals. In vitro studies about neutrophils migration were also conducted. Our data showed that intestinal IR increased intestinal vascular and mucosal permeability, 
recruitment/activation of neutrophils, intestinal motility and ex vivo reactivity to methacoline. There was a reduction of exsudate intestinal fluid volume that was accompanied by an increase of TNF- $\alpha$ and IL-10 levels and leukocytes numbers. Systemically, intestinal IR increased the white blood cell counts and reduced the bone marrow cell counts. Serum alkaline phosphatase, LDH and all quantified cytokines and chemokines were found increased after intestinal I/R. Regarding the in vitro migration assay we observed that the neutrophil migration after intestinal IR was increased. Estradiol treatment, showed that both (E30 and E24) reduced TNF- $\alpha$ and leukocytes in the intestinal fluid, neutrophils recruitment/activation, LDH and IL-1 $\beta$, IL-10, VEGF, MIP-1 $\alpha$, MCP-1, GRO/KC e IP-10. Preventive treatment (E24) reduced the intestinal vascular permeability but increased intestinal motility and bone marrow cell counts. On the other hand, therapeutic treatment (E30) reduced the intestinal mucosal permeability, white blood cell counts and serum concentrations of alkaline phosphatase, IL-6, TNF- $\alpha$ and GM-CSF.

Overall, our results suggest that the systemic and local repercussions of intestinal IR were attenuated by estradiol administration in the context of therapeutic and preventive treatment of the rats. Since that intestinal inflammation could lead to important systemic consequences, our data allow us to suggest that estradiol could be an interesting pharmacological alternative in the control and understanding of the mechanisms triggered by intestinal ischemic events followed by reperfusion.

Keywords: Inflammation. Intestinal Ischemia and Reperfusion. Estradiol. Rats. 


\section{LISTA DE GRÁFICOS}

Gráfico 1 - Extravasamento do corante azul de Evans (AE) no intestino de ratos submetidos à isquemia (45 min) e reperfusão intestinal (2 horas - IR intestinal). Os grupos consistiram de animais tratados com estradiol 30 min após ou 24 h antes da indução da isquemia, falsamente submetidos a IR intestinal (Sham) e animais não manipulados (Basal). Os dados representam a média \pm EPM de 8-12 experimentos. ${ }^{\phi} \mathrm{P}<0,05$ em relação ao grupo Basal; $* P<0,05$ em relação ao grupo Sham; ${ }^{\gamma} \mathrm{P}<0,05$ em relação ao grupo IR intestinal. .46

Gráfico 2 - Permeabilidade do intestino de ratos submetidos à isquemia (45 min) e reperfusão intestinal (2 horas - IR intestinal) ao Dextran-FITC. Os grupos consistiram de animais tratados com estradiol $30 \mathrm{~min}$ após ou $24 \mathrm{~h}$ antes da indução da isquemia e falsamente submetidos a IR intestinal (Sham). Os dados representam a média \pm EPM de 4-7 experimentos. $* P<0,05$ em relação ao grupo Sham; ${ }^{\gamma} \mathrm{P}<0,05$ em relação ao grupo IR intestinal.

Gráfico 3 - Valores de atividade da enzima mieloperoxidase (MPO) em homogenatos de duodeno de ratos submetidos à isquemia $(45 \mathrm{~min})$ e reperfusão intestinal (2 horas - IR intestinal). Os grupos consistiram também de animais tratados com estradiol 30 min após ou $24 \mathrm{~h}$ antes da indução da isquemia, falsamente submetidos a IR intestinal (Sham) e animais não manipulados (Basal). Os dados representam a média \pm EPM de 5-8 experimentos. $* P<0,05$ em relação ao grupo Sham

Gráfico 4 - Porcentagem, em relação ao comprimento total do intestino delgado, de trânsito do carvão ativado (20\%), administrado antes dos ratos serem submetidos à IR intestinal. Os grupos consistiram de animais tratados com estradiol 30 min após ou 24 h antes da indução da isquemia, falsamente submetidos a IR intestinal (Sham) e animais não manipulados (Basal). Os dados representam a média \pm EPM de 5-9 experimentos. ${ }^{\mu} \mathrm{P}<0,05$ em relação ao grupo Basal; ${ }^{\phi} \mathrm{P}<0,05$ em relação ao grupo Basal; ${ }^{*} \mathrm{P}<0,05$ em relação ao grupo Sham; ${ }^{\gamma} \mathrm{P}<0,05$ em relação ao grupo IR intestinal.

Gráfico 5 - Resposta contrátil ao $\mathrm{KCl}$ de segmentos de íleo in vitro de ratos submetidos à isquemia (45 min) e reperfusão intestinal (2 horas - IR intestinal). Os grupos consistiram de animais tratados com estradiol 30 min após ou 24 h antes da indução da isquemia, falsamente submetidos a IR intestinal (Sham) e animais não manipulados (Basal). Os dados representam a média \pm EPM de 7-11 experimentos. 
Gráfico 6 - Reatividade de íleo isolado de ratos submetidos à IR intestinal (Painel A e C) e a área sob a curva (area under the curve - AUC) dessas curvas de dose-resposta (Painel B e D). Os grupos também consistiram de animais tratados com estradiol (30 min após ou 24 h antes da indução da isquemia), falsamente submetidos a IR intestinal (Sham) e animais não manipulados (Basal). Os dados representam a média \pm EPM de 7-12 experimentos. ${ }^{*} \mathrm{P}<0,05$ em relação ao grupo Sham .55

Gráfico 7 - Volume de fluido intestinal recuperado após o isolamento do intestino em embalagem plástica de ratos submetidosa IR intestinal.. Os grupos também consistiram de animais tratados com estradiol 30 min após ou 24 h antes da indução da isquemia e como controle animais falsamente submetidos a IR intestinal (Sham). Os dados representam a média \pm EPM de 5-6 experimentos. $* P<0,05$ em relação ao grupo Sham. 57

Gráfico 8 - Concentração de azul de Evans (AE) presente no fluido intestinal recuperado na embalagem plástica de ratos submetidos à IR intestinal. Os grupos consistiram também de animais tratados com estradiol 30 min após ou 24 h antes da indução da isquemia e como controle animais falsamente submetidos a IR intestinal (Sham). Os dados representam a média \pm EPM de 6-7 experimentos. ${ }^{\gamma} \mathrm{P}<0,05$ em relação ao grupo IR intestinal .59

Gráfico 9 - Concentração de IL-10 no líquido intestinal recuperado da embalagem plástica de ratos submetidos à IR intestinal. Os grupos também consistiram de animais tratados com estradiol $30 \mathrm{~min}$ após ou $24 \mathrm{~h}$ antes da indução da isquemia e como controle animais falsamente submetidos a IR intestinal (Sham). Os dados representam a média \pm EPM de 3-7 experimentos. $* P<0,05$ em relação ao grupo Sham

Gráfico 10 - Concentração de TNF- $\alpha$ no líquido intestinal recuperado da embalagem plástica de ratos submetidos à IR intestinal. Os grupos também consistiram de animais tratados com estradiol 30 min após ou $24 \mathrm{~h}$ antes da indução da isquemia e como controle animais falsamente submetidos a IR intestinal (Sham). Os dados representam a média \pm EPM de 9-10 experimentos. $* P<0,05$ em relação ao grupo Sham; ${ }^{\gamma} \mathrm{P}<0,05$ em relação ao grupo IR intestinal

Gráfico 11 - Número total de células na medula óssea em grupos dos ratos após a indução da IR intestinal. Os grupos também consistiram de animais tratados com estradiol 30 min após ou $24 \mathrm{~h}$ antes da indução isquemia, animais falsamente submetidos a IR intestinal (Sham) e animais não manipulados (Basal). Os dados representam a média \pm EPM de 10-14 
experimentos. ${ }^{\phi} \mathrm{P}<0,05$ em relação ao grupo Basal; $* \mathrm{P}<0,05$ em relação ao grupo Sham; ${ }^{\gamma} P<0.05$ em relação ao grupo IR intestinal...

Gráfico 12 - Ensaio de migração de neutrófilos de ratos submetidos à IR intestinal. Os grupos também consistiram de animais tratados com estradiol 30 min após ou 24 h antes da indução da isquemia e de animais falsamente submetidos a IR intestinal (Sham). Os dados representam a média \pm EPM de 7-8 experimentos. ${ }^{*} \mathrm{P}<0,05$ em relação ao grupo Sham; ${ }^{\gamma} \mathrm{P}<0,05$ em relação ao grupo IR intestinal. . .71

Gráfico 13 - Atividade de fosfatase alcalina no soro de ratos submetidos à intestinal. Os grupos consistiram de animais tratados com estradiol 30 min após ou 24 h antes da indução da isquemia), animais falsamente submetidos a IR intestinal (Sham) e animais não manipulados (Basal). Os dados representam a média \pm EPM de 8-13 experimentos. $* \mathrm{P}<0,05$ em relação ao grupo Sham; ${ }^{\gamma} \mathrm{P}<0,05$ em relação ao grupo IR intestinal. .73

Gráfico 14 - Concentração de lactato desidrogenase (LDH) no soro de ratos submetidos à IR intestinal. Os grupos também consistiram de animais tratados com estradiol 30 min após ou $24 \mathrm{~h}$ antes da indução da isquemia), animais falsamente submetidos a IR intestinal (Sham) e animais não manipulados (Basal). Os dados representam a média \pm EPM de 8-13 experimentos. ${ }^{*} \mathrm{P}<0,05$ em relação ao grupo $\mathrm{Sham} ;{ }^{\gamma} \mathrm{P}<0,05$ em relação ao grupo IR intestinal. 


\section{LISTA DE TABELAS}

Tabela 1 - Concentração sérica de estradiol $(\mathrm{pg} / \mathrm{mL})$ de ratos submetidos à isquemia (45 min) e reperfusão intestinal ( 2 horas - IR intestinal). Havendo dois tratamentos com 17ß-estradiol um após $30 \mathrm{~min}$ do início da isquemia (E30 - $280 \mu \mathrm{l} / \mathrm{kg}$, i. v.) e $24 \mathrm{~h}$ antes da isquemia (E24 $280 \mu \mathrm{l} / \mathrm{kg}$, s. c.). Os dados representam a média \pm EPM de 6 experimentos. ${ }^{\gamma} \mathrm{P}<0,05$ em relação ao grupo IR intestinal.

Tabela 2 - Número de leucócitos totais e diferencial (x $\left.10^{3} / \mathrm{mL}\right)$ encontrados no líquido intestinal recuperado da embalagem plástica dos ratos após a IR intestinal. Os grupos de estudo consistiram de animais tratados com estradiol 30 min após ou 24 h antes da indução da isquemia e também como controle animais falsamente submetidos a IR intestinal (Sham). Os dados representam a média \pm EPM de 8-10 experimentos. ${ }^{*} \mathrm{P}<0,05$ em relação ao grupo Sham; ${ }^{\gamma} \mathrm{P}<0,05$ em relação ao grupo IR intestinal.

Tabela 3 - Contagem total de leucócitos, diferencial (linfócitos, monócitos e granulócitos) e plaquetas $\left(\mathrm{mm}^{3}\right)$ no sangue de ratos submetidos à isquemia (45 min) e reperfusão intestinal (2 horas - IR intestinal). Os grupos consistiram de animais tratados com estradiol 30 min após ou $24 \mathrm{~h}$ antes da indução da isquemia, animais falsamente submetidos a IR intestinal (Sham) e animais não manipulados (Basal). Os dados representam a média \pm EPM de 17 - 26 experimentos. ${ }^{*} \mathrm{P}<0.05$ em relação ao valor inicial do experimento de cada grupo; ${ }^{\alpha} \mathrm{P}<0.05$ em relação ao valor final do grupo Sham; ${ }^{\gamma} \mathrm{P}<0.05$ em relação ao valor final do grupo IR intestinal

Tabela 4 - Quantificação de mediadores (pg/mL) no soro de ratos submetidos à IR intestinal. Os grupos também consistiram de animais tratados com estradiol 30 min após ou 24 h antes da indução da isquemia, animais falsamente submetidos a IR intestinal (Sham) e animais não manipulados (Basal). Os dados representam a média \pm EPM de 10-12 experimentos. ${ }^{\phi} \mathrm{P}<0,05$ em relação ao grupo Basal; $* \mathrm{P}<0,05$ em relação ao grupo Sham; ${ }^{\gamma} P<0.05$ em relação ao grupo IR intestinal. 


\section{LISTA DE ABREVIATURAS E SIGLAS}

AE Azul de Evans

Akt Serina/treonina quinase

AMS Artéria mesentérica superior

AP-1 Proteína ativadora 1

ATP Trifosfato de adenosina

AUC Área sob a curva

cAMP Monofosfato cíclico de adenosina cíclica

CINC-1 Citocina indutora de quimiotaxia de neutrófilos-1

CINC-3 Citocina indutora de quimiotaxia de neutrófilos-3

cNOS Óxido nítrico sintase constitutiva

COX Cicloxigenase

DNA Ácido desoxirribonucléico

EDTA Ácido etilenodiamino tetra-acético

eNOS Óxido nítrico sintase endotelial

ER Receptor de estradiol

ER- $\boldsymbol{\alpha}$ Receptor de estradiol- $\alpha$

ER- $\boldsymbol{\beta}$ Receptor de estradiol- $\beta$

ERE Elementos responsíveis ao estradiol

ERR Receptores relacionados ao estrógeno

ERRE Elementos responsíveis à ERR

GM-CSF Estimulador de colônias de granulócitos e macrófagos 
GPER Receptor de estradiol ligado à proteína $\mathrm{G}$

GPR-30 Receptor de estradiol ligado à proteína G30

GRO/KC Oncogene relacionado ao crescimento/quimiotático de queratinócitos

HSF Hormônios sexuais femininos

HTAB Brometo de hexadecil-tri-metil-amônio

ICAM-1 Molécula de adesão intracelular tipo 1

IFN Interferon

IFN- $\gamma$ Interferon- $\gamma$

IL-1 $\alpha$ Interleucina- $\alpha$

IL-1及 Interleucina- $\beta$

IL-2 Interleucina-2

IL-4 Interleucina-4

IL-5 Interleucina-5

IL-6 Interleucina-6

IL-8 Interleucina-8

IL-10 Interleucina-10

IL-12 Interleucina-12

IL-12p70 Interleucina-12p70

IMOS Insuficiência múltipla de órgãos e sistemas

iNOS Óxido nítrico sintase induzida

i.p. Administração via intraperitôneal

IP-10 Proteína induzida pelo IFN- $\gamma-10$ 
IR Isquemia e reperfusão

i.v. Administração via intravenosa

LDH Lactato desidrogenase

LOX Lipoxigenase

LPS Lipopolisacarídeo

MCP-1a Proteína quimiotática de monócitos-1

MIP-1 Proteína inflamatória de macrófagos-1 $1 \alpha$

MPAK Proteína quinase ativada por mitógeno

MPO Mieloperoxidase

NF-кB Fator nuclear kappa B

NANC Não adrenérgicos e não colinérgicos

NO Óxido nítrico

NOS Óxido nítrico sintase

PAF Fator ativador de plaquetas

PBS Salina tamponada fosfatada

PI3K Fosfatidilinositos-3-quinase

PI3K/Akt Fosfatidilinositos-3-quinase/ Serina/treonina quinase

s.c. Administração via subcutânea

RNA Ácido ribonucléico

SMT S-metilisotioureia

TNF Fator de necrose tumoral

TNF- $\alpha$ Fator de necrose tumoral- $\alpha$ 
TLR4 Toll like receptor-4

UTIs Unidade de terapia intensiva

VCAM-1 Molécula de adesão vascular-1

VEGF Fator de crescimento endotelial vascular

VIP Peptídeo vasoativo intestinal 


\section{SUMÁRIO}

1 INTRODUÇÃ

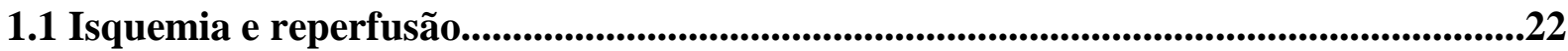

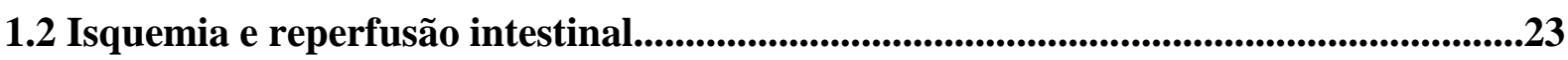

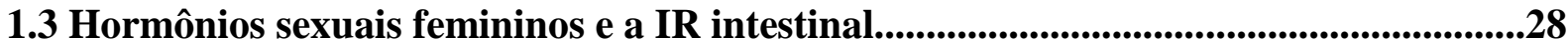

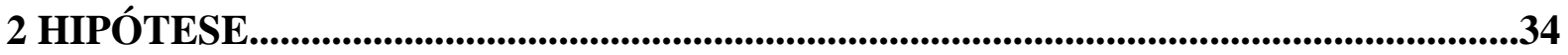

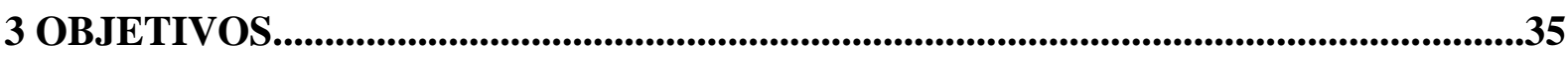

4 MATERIAIS E MÉTODOS........................................................................................36

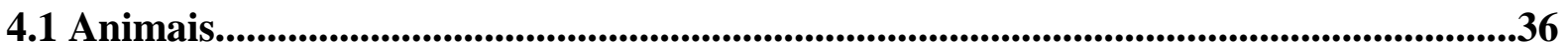

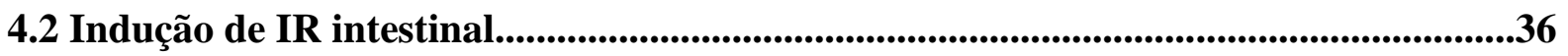

4.3 Tratamentos farmacológicos......................................................................................................36

4.4 Determinação dos níveis séricos hormonais...........................................................37

4.5 Estudo da permeabilidade vascular intestinal......................................................................37

4.6 Estudo da permeabilidade da mucosa intestinal..........................................................37

4.7 Estudo do recrutamento/ativação de neutrófilos no intestino....................................38

4.8 Estudo da motilidade intestinal.....................................................................................38

4.9 Estudo da reatividade de segmentos de íleo isolado......................................................38

4.10 Coleta e análise do fluido/líquido intestinal obtido durante a IR intestinal...............39

4.11 Determinação dos níveis de IL-10 e TNF- $\alpha$ no fluido intestinal obtido durante a IR

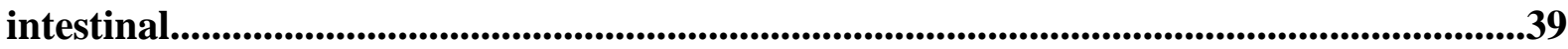

4.12 Determinação número total e diferencial de leucócitos e do número de plaquetas

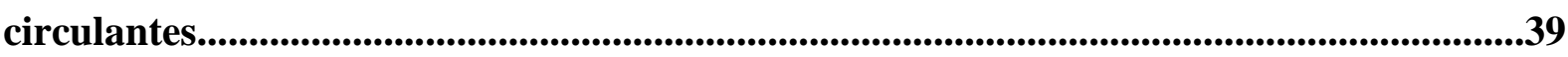

4.13 Determinação do número total de células na medula óssea...........................................40

4.14 Ensaio de quimiotaxia in vitro com neutrófilos do sangue...........................................40 
4.15 Determinação da atividade sérica de fosfatase alcalina e lactato desidrogenase.......41

4.16 Determinação dos níveis de mediadores inflamatórios no soro.....................................41

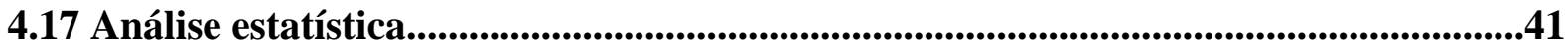

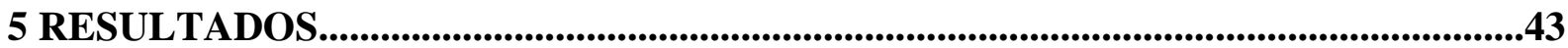

5.1 Determinação da concentração de estradiol no soro de animais tratados.....................43

5.2 Efeito da IR intestinal e do tratamento dos animais com estradiol sobre o aumento da permeabilidade vascular no intestino......................................................................45

5.3 IR intestinal e o tratamento dos animais com estradiol no aumento da permeabilidade da mucosa intestinal.........................................................................................47

5.4 Efeito da IR intestinal e do tratamento dos animais com estradiol sobre a atividade da enzima mieloperoxidase no intestino.

5.5 Repercussão da IR intestinal e efeito do tratamento dos animais com o estradiol no

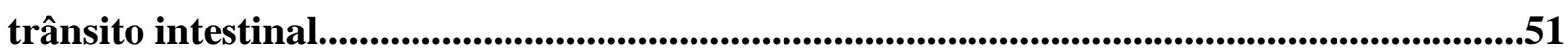

5.6 Influência da IR intestinal e do tratamento dos animais com estradiol na reatividade à metacolina de segmentos de íleo isolado. .53

5.7 Efeito da IR intestinal e do tratamento dos animais com estradiol sobre o líquido intestinal produzido. .56

5.8 Efeito da IR intestinal sobre o número de leucócitos e de plaquetas circulantes .66

5.9 Efeito da IR intestinal e do tratamento dos animais com estradiol sobre o número de células da medula óssea .68

5.10 Efeito da IR intestinal e do tratamento dos animais com estradiol sobre a migração in vitro de neutrófilos.

5.11 Efeito da IR intestinal e do tratamento dos animais com estradiol sobre a concentração no soro de fosfatase alcalina e lactato desidrogenase.

5.12 Efeito da IR intestinal e do tratamento dos animais com estradiol sobre a concentração no soro de mediadores......................................................................................................76

6 DISCUSSÃO 


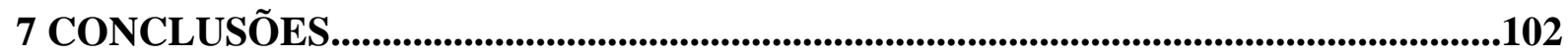

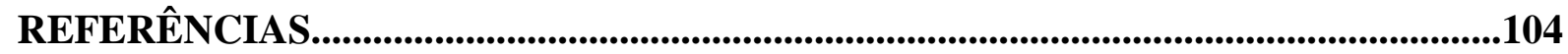




\section{INTRODUÇÃ̃o}

\subsection{Isquemia e Reperfusão}

A isquemia é um evento caracterizado pela obstrução total ou parcial do suprimento sanguíneo a um órgão ou região. A reperfusão é a restauração deste suprimento (ELTZSCHIG; ECKLE, 2011). A isquemia é responsável pela diminuição de oxigênio e do aporte de nutrientes para a área afetada e, como consequência o metabolismo aeróbico é comprometido. Desta forma, ocorre redução dos estoques de trifosfato de adenosina (ATP), acúmulo de ácido lático, aumento da geração de espécies reativas de oxigênio e nitrogênio, produção e liberação de mediadores inflamatórios e indução de fatores transcrição, como fator nuclear $\kappa \mathrm{B}(\mathrm{NF}-\kappa \mathrm{B})$, proteína ativadora 1 (AP-1) que regulam a expressão de genes próinfamatórios, tais eventos culminam com a produção de enzimas, citocinas, e expressão moléculas de adesão (BALAKUMAR et al., 2008; CERQUEIRA et al., 2005; ZUIDEMA; ZHANG, 2010).

Existem evidências de que o efeito lesivo e inflamatório da isquemia se deve à geração de produtos tóxicos gerados durante o evento isquêmico, que são então disseminados no período de reperfusão, momento no qual a circulação sanguínea é retomada. Havendo o restabelecimento da oxigenação dos tecidos ocorre aumento do influxo de cálcio para o meio intracelular. Com isto aumenta a atividade de fosfolipase $A_{2}$ que libera ácido araquidônico, o qual é metabolizado pela enzima cicloxigenase (COX) e gera prostaglandinas, tromboxana e prostaciclina, assim como leucotrienos, pela atividade da enzima lipoxigenase (LOX). Da ação destes mediadores resulta aumento da permeabilidade vascular, agregação plaquetária e quimiotaxia de células polimorfonucleares (BERTHIAUME et al., 1999; CERQUEIRA et al., 2005; ELTZSCHIG; CARMELIET, 2011; GIRN et al., 2007).

As alterações do organismo desencadeadas pela isquemia e reperfusão (IR) podem resultar em lesões teciduais locais e distantes de onde foi gerada a isquemia (BERTHIAUME et al., 1999; HO et al., 2009). Paradoxalmente, da mesma forma que a restauração da circulação pode ser lesiva, ela também é o evento necessário para o restabelecimento da homeostasia (PARKS; GRANGER, 1986). Em condições nas quais os limites da homeostasia são ultrapassados, a IR pode desencadear outras síndromes clínicas como lesão do miocárdio, acidente vascular cerebral e lesão pulmonar. Tais eventos contribuem para o 
desencadeamento da falência múltipla de órgãos e sistemas (HALLDORSSON et al., 2000; ZUIDEMA; ZHANG, 2010).

\subsection{Isquemia e Reperfusão intestinal}

A isquemia da região esplâncnica é um evento clínico relevante, pois a região gastrintestinal recebe de 10 a $25 \%$ do débito cardíaco e destes, 70 a $90 \%$ suprem a mucosa e submucosa intestinal. Dentre os eventos isquêmicos da região esplâncnica com potencial capacidade lesiva para o organismo, destacam-se aqueles decorrentes da obstrução do fluxo das artérias mesentéricas. Os principais ramos da artéria mesentérica superior (AMS) compreendem a artéria pancreático-duodenal inferior, artéria cólica média, artéria cólica direita, 4-6 ramos do jejuno, 9-13 ramos do íleo. A AMS em humanos é responsável pelo suprimento de sangue para áreas tais como: pâncreas, intestino delgado e parte do cólon (ROSENBLUM et al.,1997). Portanto, segmentos do intestino delgado e grosso podem ser alvos de lesões isquêmicas, decorrentes da interrupção do fluxo da AMS. Exemplos de lesões intestinais graves são a colite isquêmica e a isquemia mesentérica. Esta última, mais grave, pode ser causada por embolia arterial, trombose arterial, patologias não oclusivas e trombose venosa mesentérica, além de causas não patológicas, como em manobras cirúrgicas (VOLLMAR; MENGER, 2011).

A primeira descrição do quadro clínico de oclusão da artéria mesentérica superior é atribuída a Allbutt e Rolleston, no século XV em Florença. Já em 1875 Litten publica o primeiro trabalho experimental dos efeitos da ligadura dos vasos mesentéricos, o qual resultou em prostração, depressão do sistema nervoso central, aumento da frequência respiratória e fezes sanguinolentas. Como consequência, diversos estudos em diferentes regiões do mundo passaram a investigar a isquemia mesentérica. Apesar de uma literatura vasta a respeito do assunto, do primeiro livro publicado em 1971 “Vascular Disorders of the Intestines”, de o diagnóstico e os cuidados terem avançaram nos últimos anos, ainda existe muito a se investigar sobre esta patologia (BOLEY et al., 1997).

Atualmente, a isquemia intestinal como causa de morte por vezes é identificada apenas durante a autópsia, sendo considerada uma emergência abdominal de grande risco à vida (BYARD, 2012; VOLLMAR; MENGER, 2011). No Brasil, os dados relativos à incidência de IR intestinal são encontrados, de acordo com a categoria CID-10 do sistema DATASUS, 
como transtornos vasculares do intestino. Nesse sentido no ano de 2011 a 2013, ocorreram cerca de 8932 óbitos no Brasil em decorrência destes transtornos. De forma geral, os eventos isquêmicos no intestino apresentam elevada taxa de mortalidade (40-70\%) e são difíceis de serem diagnosticados. As causas desta dificuldade são as diversas etiologias da isquemia mesentérica tais como a embolia, trombose, compressão extrínseca, vaso espasmos induzido por drogas vasoativas, alteração da coagulação e processo infeccioso ou inflamatório (BYARD, 2012; RIBEIRO; YOSHIDA, 2005; VAN DEN HEIJKANT et al., 2013; VOLLMAR; MENGER, 2011). Muitos dos seus sinais e sintomas podem ser confundidos com os da pancreatite, colecistite, apendicite, diverticulite e obstrução intestinal (VAN DEN HEIJKANT et al., 2013; WYERS, 2010).

Uma vez instalada, a isquemia mesentérica pode causar lesão da mucosa intestinal, aumentar a permeabilidade microvascular e causar a perda de fluido para a luz intestinal. Nestas condições são liberadas localmente enzimas proteolíticas e também ocorre liberação sistêmica de um amplo contingente de fatores e mediadores inflamatórios, cujos efeitos em conjunto podem causar choque circulatório. Essa situação pode se agravar na reperfusão, quando radicais livres lesaram a membrana celular e neutrófilos uma vez são recrutados podem liberar mediadores inflamatórios. Esses fatores em conjunto com o aumento da permeabilidade capilar são os principais determinantes da instabilidade hemodinâmica e lesão tecidual (BYARD, 2012; CHEN et al., 2003; GROTZ et al., 1999; RIBEIRO; YOSHIDA, 2005, VOLLMAR; MENGER, 2011). As alterações histológicas intestinais decorrentes podem ser desde a diminuição das vilosidades e profundidade das criptas, como descamações da cobertura epitelial das vilosidades, necrose epitelial e desintegração da lâmina própria, com consequente ulceração e hemorragia (RIBEIRO; YOSHIDA, 2005; TÓTH et al., 2012).

A liberação de produtos de peroxidação lipídica no intestino ou no sangue, está diretamente relacionada ao dano epitelial. O radical hidroxila é o mais reativo dos radicais livres, reagindo com todas as substâncias biológicas, como proteínas, polissacárides e ácidos graxos polinsaturados, componentes das membranas celulares. Este radical é de grande importância uma vez que a reação entre as membranas celulares e o radical hidroxila resulta na peroxidação lipídica de membrana, levando ã desintegração e morte celular (YOSHIDA, 1996).

O epitélio intestinal é composto de uma camada única de células, sendo elas: células absortivas ou enterócitos, células caliciformes, células de Paneth e células enteroendócrinas, distribuídas no epitélio em regiões específicas dos vilos e criptas intestinais. Os enterócitos, 
por exemplo, compõem $95 \%$ de toda população de células epiteliais do intestino delgado (TÓTH et al., 2012). As células presentes na ponta das vilosidades são mais sensíveis ao insulto da IR intestinal, devido a sua localização em relação a microvascularização intestinal e sua maior susceptibilidade à apoptose. Além da morte de células do topo das vilosidades, as células presentes nas criptas também são afetadas, em especial as células de Paneth. Estas ficam localizadas na base das criptas de Lieberkühn, e são consideradas células inflamatórias, pois secretam mediadores pró-inflamatórios e são a fonte primária da produção de produtos antimicrobianos, cruciais para manter a homeostase das bactérias da flora intestinal, controlando assim a translocação bacteriana (GROOTJANS et al., 2011; LENAERTS et al., 2013). A função secretora das células de Paneth faz com que elas sejam susceptíveis ao estresse no retículo endoplasmático. Este estresse se caracteriza pelo acúmulo de proteínas mal enoveladas no retículo endoplasmático, levando à redução de sua taxa de tradução de proteínas. Nestas condições mecanismos reparadores são acionados fazendo com que ocorra a expansão de vias de secreção. Quando tais mecanismos não são efetivos ocorre acúmulo de proteínas mal enoveladas. Isto faz com que as células reduzam sua taxa de tradução de proteínas adequadamente enoveladas levando a apoptose (KASER; BLUMBERG, 2010).

Outra célula afetada pelo estresse do retículo endoplasmático são as células caliciformes, que tem seu número reduzido especialmente nas vilosidades após o período de $1 \mathrm{~h}$ de reperfusão (TÓTH et al., 2012) e em modelo de trauma seguido de choque hemorrágico (CHANG et al., 2005). Estas células são responsáveis pela secreção da maioria das glicoproteínas da camada de muco que recobre as células epitelias do intestino. Essa camada de muco representa a primeira barreira de defesa do intestino (KASER; BLUMBERG, 2010; KIM; HO, 2010). Estudos de Qin et al., (2011) mostraram que a camada de muco está diretamente ligada com a função da barreira intestinal, visto que na ausência de muco intestinal ocorre o aumento da permeabilidade e lesão intestinal.

Além de dano na mucosa intestinal estudos de Pontell et al., (2011) indicaram que a IR intestinal é capaz de inflamar, o que está associado ao rápido aumento de neutrófilos tanto na mucosa, como nas camadas de músculo. Como consequência ocorre dano da musculatura longitudinal no intestino delgado e da motilidade intestinal. Tal consequência também está associada a degeneração de neurônios entéricos, com consequente perda de alguns deles após a IR intestinal (CALCINA et al., 2005).

É importante citar também o papel do NF- $\kappa B$ ativado pelo estímulo inflamatório da IR. Este fator coordena a expressão de proteínas envolvidas na síntese de mediadores e na 
amplificação e manutenção da resposta inflamatória (CERQUEIRA et al., 2005). O sistema complemento pode ser um dos responsáveis pelo aumento de $\mathrm{NF}-\kappa \mathrm{B}$, também sendo capaz de aumentar a transcrição de enzima óxido nítrico sintase (NOS) induzida em células epiteliais. O componente C5, por exemplo, pode mediar a lesão por IR intestinal pela regulação de molécula de adesão intercelular-1 (ICAM-1), fator de necrose tumoral- $\alpha$ (TNF- $\alpha$ ) e interleucina-1 $\alpha$ (IL-1 $\alpha)$ (MONTALTO et al., 2003).

Os mastócitos também parecem estar relacionados com o aumento da lesão após IR intestinal, contribuindo para o aumento da permeabilidade da mucosa intestinal e motilidade intestinal, visto que liberam um amplo espectro de mediadores inflamatórios (citocinas, histamina, leucotrienos, serotonina e fator de ativação plaquetária (PAF), os quais parecem estar envolvidos no recrutamento de neutrófilos, existindo assim indicação de que os mastócitos são que ajudam no recrutamento de neutrófilos no tecido (BOROS et al., 1995; CERQUEIRA et al., 2005; KUBES et al., 1996).

Evidências sugerem que além de células polimorfonucleares e endoteliais, as plaquetas podem estar envolvidas nas repercussões da IR intestinal. Plaquetas podem gerar radicais livres, liberar mediadores pró-inflamatórios, além de modular a função leucocitária (COOPER et al., 2003; MASSBERG; MESSMER, 1998).

O evento inflamatório da IR intestinal inclui a liberação de fatores quimiotáxicos que mobilizam células inflamatórias, notadamente os neutrófilos (XU et al., 2009). Com respeito aos neutrófilos sabe-se que estas células produzem radicais livres, como superóxido e peróxido de hidrogênio, além de secretar a enzima mieloperoxidase (MPO), a responsável pela formação de ácido hipocloroso. Os neutrófilos ativados também produzem enzimas proteolíticas, as quais são capazes de degradar a membrana basal e as proteínas que fazem a junção celular das células endoteliais, além de serem responsáveis pela produção de mediadores lipídicos tais como prostaglandinas, tromboxanos, PAF. Os neutrófilos também estão também envolvidos na oclusão da microcirculação durante o período de reperfusão (chamado fenômeno de no-reflow) ao ocluírem a microcirculação, quando se aderem a parede dos capilares, dificultando assim o fluxo sanguíneo (CARDEN; GRANGER, 2000; ELTZSCHIG; ECKLE, 2011; WELBORN et al., 1991).

À luz dessas informações, a reversão do evento isquêmico por meio da reperfusão da área afetada, como já citado, é essencial para que o organismo reorganize sua homeostasia. Parks e Granger, (1986) mostraram que o intestino de animais submetidos a $3 \mathrm{~h}$ de isquemia e $1 \mathrm{~h}$ de reperfusão se torna mais comprometido do que o intestino de animais submetidos 
somente à isquemia (neste caso de $4 \mathrm{~h}$ ). Portanto, é importante ressaltar que mesmo a reperfusão sendo fundamental para evitar que a injúria local ocorra, o reestabelecimento do fluxo sanguíneo pode também induzir o desencadeamento de uma resposta inflamatória e afetar a integridade funcional de diversos órgãos. O chamado "reflow-paradox", está associado com a adesão de leucócitos na parede endotelial de vênulas pós-capilares e ativação leucocitária, aumentando a permeabilidade microvascular (DEITCH, 1992; KAWASAKI; CHAUDRY, 2012a, 2012b; MASSBERG; MESSMER, 1998; VOLLMAR; MENGER, 2011).

Modelos experimentais de isquemia e reperfusão intestinal (STALLION et al., 2005; Ben et al., 2012), ou mesmo de trauma seguido de choque hemorrágico (DEITCH, 2001) investigam as repercussões locais e sistêmicas, notadamente no pulmão. É interessante ressaltar que ambos os modelos (isquemia e reperfusão intestinal ou de trauma seguido de choque hemorrágico) resultam em quadro de hipoperfusão intestinal e, portanto, podem ser comparados. Porém devemos considerar o fato de que o bloqueio do fluxo sanguíneo durante a isquemia é agudo e no choque hemorrágico o estabelecimento da hipoperfusão ocorre de forma lenta, gradual e sistêmica. Ainda, entendemos que as alterações fisiológicas, após a IR intestinal, começam no intestino e que por outro lado as originadas pelo choque hemorrágico resultam da perda de volume e do mecanismo de compensação deflagrado na circulação esplâncnica.

Deve-se ressaltar que apesar de os vários estudos com modelos de IR intestinal concentrarem seu foco no pulmão (KAWASAKI; CHAUDRY, 2012a; VOLLMAR; MENGER, 2011), eventos isquêmicos intestinais seguidos de sua reperfusão também se relacionam com a indução de inflamação renal (KAWASAKI; CHAUDRY, 2012b; LA NOUE et al., 1996), hepática (KAWASAKI; CHAUDRY, 2012b; ZHAO et al., 2010), esplênica (KAWASAKI; CHAUDRY, 2012b) ou cardíaca (KAWASAKI; CHAUDRY, 2012a).

Considerando as alterações causadas pela IR intestinal e o fato de a reperfusão da área isquêmica disseminar para a circulação produtos tóxicos, o intestino pode ser considerado como o "motor" da inflamação sistêmica e contribuir para a insuficiência de múltiplos órgãos e sistemas (IMOS) (THOMAS et al., 2002; VOLLMAR; MENGER, 2011). Narita et al., (2004) mostraram que o isolamento do intestino da cavidade abdominal, durante o período de IR intestinal, impede que mediadores produzidos no intestino adentrem à circulação sistêmica, protegendo o pulmão dos efeitos lesivos e diminuindo as repercussões pulmonares resultantes 
da IR intestinal. Desta forma fortalece-se o conceito da importância do intestino na indução da inflamação.

Um aspecto interesante no controle da inflamação intestinal causada pela IR intestinal, por meio da obstrução da artéria mesentérica superior ou após o trauma seguido de choque hemorrágico é o papel dos hormônios sexuais femininos. Nesse sentido mulheres sob trauma intestinal geram menores concentrações séricas de citocinas inflamatórias e, que isto reduz o índice de aparecimento da IMOS (FRINK et al., 2007). Da mesma forma estudos de Deitch et al., (2008) mostraram que ratas apresentam maior resistência à injúria intestinal após IR intestinal, assim como o dano a órgãos distantes. Ainda, a literatura também relata a participação dos hormônios sexuais femininos (HSF) na mediação das repercussões pulmonares e sistêmicas causadas pelo trauma seguido de choque hemorrágico (ANGELE et al., 2000, 2006; CHAUDRY et al., 2003; HILDEBRAND et al., 2006; KNÖFERL et al., 2001, 2002; MELDRUM, 2006; MOEINPOUR et al., 2007). Recentemente mostramos que o estradiol reduz a inflamação pulmonar causada pela IR intestinal em ratas e que administração desse hormônio pode proteger ou mesmo ter efeito terapêutico sobre a inflamação pulmonar em ratos após a IR intestinal (BREITHAUPT-FALOPPA et al., 2013, 2014).

\subsection{Hormônios sexuais femininos e a IR intestinal}

Existem evidências de que a resposta imune (inata e adaptativa) seja diferente entre os sexos. Durante o ciclo sexual feminino é possível observar uma mudança de perfil Th1, durante a menstruação e fase lútea, para Th2 na fase folicular (FISH, 2008). Sendo estes perfis diferentes, o Th1 está associado à resposta imune celular que leva ao dano tecidual, como em doenças imunes crônicas se caracterizando pela liberação de citocinas como IFN- $\alpha$, interleucina-12 (IL-12) e TNF. Já o perfil Th2 está ligado a resposta imune mediada por anticorpos, envolvida particularmente com respostas alérgicas, se caracterizando pela liberação de citocinas diferentes das do perfil Th1, são elas interleucina-4 (IL-4), interleucina5 (IL-5) e interleucina-10 (IL-10) (STRAUB et al., 2007).

Estudos clínicos mostram que mulheres, quando comparadas aos homens, apresentam menor ocorrência de sepse, pneumonia e IMOS (DEITCH et al., 2007; GROSSMANN, 1985; OLSEN; KOVACS, 1996; SCHRODER et al., 2000). Reforçando o papel dos hormônios 
sexuais no controle da homeostasia gastrintestinal, existem dados indicando que a prevalência de úlcera duodenal em mulheres é menor do que em homens (LAM et al., 1994; SCHABOWSKI; PITERA, 2004; WU et al., 2008). Mesmo em casos de distúrbios cardiovasculares as mulheres hormonalmente ativas estão mais protegidas, sendo que o casos mais graves descritos em mulheres na pós-menopausa (STANGL et al., 2002).

Ainda, evidências clínicas e experimentais, mostraram o papel do estradiol sobre o sistema imune e sua interferência no desenvolvimento de lesão pulmonar ou sistêmica após a isquemia intestinal ou em decorrência de trauma (ANGELE et al., 2000, 2006; CHAUDRY et al., 2003; DEITCH et al., 2007; RAJU; CHAUDRY, 2008) e experimentais (KNÖFERL et al., 2001, 2002; CHAUDRY et al., 2003; HILDEBRAND et al., 2006; RAJU; CHAUDRY, 2008; ZECKEY et al., 2011). Estudos experimentais mostraram que o intestino de machos em condições de choque ao serem tratados com estradiol tinham as lesões inflamatórias intestinais atenuadas (HOMMA et al., 2005). Da mesma forma, as repercussões no intestino causadas pela IR intestinal, em machos ou fêmeas ovarictomizadas, também são atenuadas após o tratamento com estradiol, em relação à analise histopatológica, expressão e atividade de óxido nítrico sintase (NOS) induzida (XIAO et al., 2004), ou no pulmão, em relação a permeabilidade vascular, influxo de leucócitos, expressão de moléculas de adesão, produção de citocinas e expressão de óxido nítrico sintase endotelial (eNOS) (BREITHAUPTFALOPPA et al., 2013, 2014).

No contexto de seus efeitos protetores, estudos clínicos mostram que o estradiol aumenta a produção de NO no sistema cardiovascular por meio do aumento da expressão de óxido nítrico sintase constitutiva (cNOS) (MENDELSOHN; KARAS, 1999). Cavriani et al., (2004) mostraram que o bloqueio das NOS (constitutiva e induzida) faz com que a sobrevivência dos animais à IR intestinal caia drasticamente. Por outro lado, a inibição da óxido nítrico sintase induzida (iNOS) não induz mortalidade desses animais. Além disso outros estudos do nosso laboratório, assim como dados da literatura indicam que o NO gerado pela eNOS tem efeitos protetores, sobre o aumento da permeabilidade vascular pulmonar e intestinal, da mesma forma ela é capaz de reduzir a iNOS, tais como o aumento da permeabilidade vascular (BREITHAUPT-FALOPPA et al., 2013, 2014; SHARAWY et al., 2013). Além disso estudos do nosso laboratório mostram que a IR intestinal causa aumento de TNF- $\alpha$ no soro, que por sua vez eleva a concentração de IL-1 $\beta$ e que a inibição de TNF- $\alpha$ faz com que a concentração de IL-10 diminua, mostrando assim uma ligação direta entre estas 
citocinas. Ainda, a inibição das enzimas NOS leva a diminuição das concentrações de tanto IL-1 $\beta$, como IL-10 (CAVRIANI et al., 2007). Podemos, portanto, estabelecer uma relação entre a atividade de NOS, estradiol e a diminuição da concentração de citocinas circulantes.

Os efeitos do estradiol são decorrentes de sua ligação a receptores, como os receptores nucleares clássicos (ER). Os receptores são classificados em: receptor $\alpha$ e receptor $\beta$. Estes subtipos estão distribuídos de forma diferente no organismo. Por exemplo temos uma prevalência de ER- $\alpha$ no rim, coração, útero, fígado e tecido adiposo, de ER- $\beta$ nos ovários, próstata, pulmões, bexiga, células hematopoiéticas e trato gastrointestinal. No intestino especificamente foi identificada uma distribuição similar de ambos os receptores, ER- $\alpha$ e ER$\beta$ (FAULDS et al., 2012; KUIPER et al., 1997). Uma vez acoplado (estradiol) e ER, os receptores se dimerizam e ligam a regiões especificas do ácido desoxirribonucleico (DNA), conhecidas como elementos responsivos ao estradiol (ERE), e localizados em promotores de genes alvo. Estudos mostram que um terço dos genes humanos que são regulados pelos ER não possuem sequências ERE. Isto sugere que outros mecanismos de regulação da transcrição existem, como a regulação de genes pelos ER sem se ligarem diretamente no DNA. É possível que ocorra por meio da modulação de fatores de transcrição no núcleo (GOTTLICHER et al., 1998; NILSSON et al., 2001; O’LONE et al., 2004).

Estudos também identificaram receptores acoplados a proteína G (GPER-1), os quais estão localizados na membrana plasmática (PROSSNITZ et al., 2008; REVANKAR et al., 2005; THOMAS et al., 2005). Admite-se que a ativação destes receptores seja crucial para que respostas biológicas sejam geradas rapidamente, tão rápidas que não poderiam ser atribuídas à ativação de ácido ribonucléico (RNA) ou síntese de proteínas e possivelmente relacionada com a ativação de uma cascata de proteínas quinases. Entre as funções atribuídas a estes receptores podemos citar a mobilização intracelular de cálcio, produção de monofosfato cíclico de adenosina cíclico (cAMP), ativação da via de proteínas quinases ativadas por mitogeno (MAPK) e da fosfatidilinusitol 3-quinase (PI3K) (BJÖRNSTRÖM; SJÖBERG, 2005; FILARDO et al., 2000; FILARDO, 2011; MAGGIOLINI et al., 2004).

No contexto do sistema de sinalização gerado pela ativação dos receptores de estrógeno existem: 1) ações genômicas clássicas, também conhecidas como "via clássica". Esta via se trata da ligação do estradiol com um ER, formando um complexo hormônio/receptor com os ERE no DNA e assim controlar a transcrição de genes; 2) ações genômicas não-clássicas, também conhecida como via não-clássica, a qual envolve a ativação de fatores de transcrição; 
e 3) ações rápidas, ou via rápida, que influenciam de forma indireta a expressão gênica pela ativação de vias de sinalização de transdução, resultando por exemplo, na modulação de segundos mensageiros e cálcio, ou da atividade de quinases. Portanto, é possível entender que a transcrição de genes alvos por meio do estradiol pode acontecer de forma direta (via clássica) ou indiretamente (via não-clássica e rápida) (BARTELLA et al., 2012; BJÖRNSTRÖM; SJÖBERG, 2005).

Vale ressaltar que recentes estudos revelam a existência de uma família de receptores órfãos, denominados receptores relacionados ao estrógeno (ERR). Estes representam uma subfamília dos receptores nucleares, existindo em três isoformas conhecidas: ERR- $\alpha$, ERR- $\beta$, ERR- $\gamma$. Expressos em órgãos como, músculo, coração, ossos e tecido adiposo. Em contraste aos ER, os ERR são constitutivamente ativos mesmo na ausência do ligante, podendo interferir com a sinalização dos estrógenos, uma vez que os ERR são capazes de se ligar à mesma região do DNA que os ER se acoplam. Contudo, os ERR se acoplam preferencialmente em regiões do DNA chamadas elementos responsivos à ERR (ERRE), nas quais os ER- $\alpha$, mas não os ER- $\beta$ podem se ligar (GIGUÉRE, 2002; MONTEIRO et al., 2014).

Estudos conduzidos em outros modelos experimentais que não a IR intestinal também mostraram que os efeitos protetores do estradiol (modelo de choque hemorrágico) como no estudo de JARRAR et al., (2000) observa-se efeitos cardioprotetores e hepáticos do estradiol. Estes autores preconizam o uso destes esteroides como agentes terapêuticos em mulheres com os ovários removidos cirurgicamente ou na pós-menopausa e que tenham sofrido choque hemorrágico. Além disso, o estradiol reduz a expressão de fatores de transcrição envolvidos na resposta inflamatória, como o NF-kB e proteína ativadora 1 (AP-1), após o choque hemorrágico experimental (SUZUKI et al., 2007a). Considerando que o NF-kB e AP-1 podem reduzir IL-1 $\beta$, interleucina-2 (IL-2), intereucina-6 (IL-6), interleucina-8 (IL-8), IFN- $\gamma$, TNF- $\alpha$ respectivamente (KESHAVARZI et al., 2012; SUZUKI et al., 2007a, 2008), o uso do estradiol pode ser de interesse no controle da inflamação sistêmica causada por trauma seguido por choque hemorrágico.

Vale lembrar que os dados existentes na literatura sugerem que os ER $\alpha$ reduzam a resposta inflamatória no fígado e no intestino após o choque hemorrágico, enquanto os ER $\beta$ se relacionam com a proteção no intestino e pulmão (YU; CHAUDRY, 2009). Ainda, tanto efeitos da ativação dos receptores $\alpha$ como a de receptores $\beta$ estão relacionados com a melhora na circulação esplâncnica em quadro de sepse experimental, possivelmente porque o estradiol 
promove efeitos protetores na microcirculação intestinal por restabelecer a atividade da eNOS e reduzir a da iNOS (SHARAWY et al., 2013). É notável que em modelo de trauma seguido de choque hemorrágico o estradiol medeia a geração de NO pela iNOS no intestino, tal efeito é mediado em grande parte pelo ER $\beta$ e em menor escala pelo ER $\alpha$, resultando em uma melhora na perfusão sanguínea do intestino (DOUCET et al., 2010). Portanto, estudos adicionais sobre a interação do NO-estradiol e de seus receptores são necessários para compreender as diferentes respostas obtidas após a expressão de ER $\alpha$ ou ER $\beta$ em modelos onde ocorre IR intestinal.

Alguns estudos mostram a associação do estradiol efeitos deletérios. Estudos clínicos (BONDS; MIDORO-HORIUTI, 2013; DE MARCO et al., 2000) mostraram uma maior incidência de asma em mulheres do que em homens. É possível que o estradiol promova a polarização da resposta imune para o perfil Th2, facilitando a produção de anticorpos e liberação dos grânulos de mastócitos e basófilos. Além disso, Diebel e Liberati, (2011) em estudo in vitro mostraram que o estrógeno está envolvido no comprometimento das células endoteliais da microvasculatura pulmonar em resposta a mediadores produzidos por células epiteliais do intestino em condições de choque. Outros estudos clínicos mostraram que em casos de trauma brusco (RAPPOLD et al., 2002) ou choque hemorrágico (SPERRY et al., 2008) mulheres não estão mais protegidas do que homens. Mesmo em modelo de isquemia no encéfalo de ratas, os estudos de Harukuni et al., (2001) mostraram que há maior morte celular em fêmeas intactas ou com reposição de estrógeno, do que em fêmeas ovariectomizadas.

Fica clara, portanto, a percepção da necessidade de novos estudos, reforçada pelas discrepâncias entre dados obtidos experimental e clinicamente acerca dos efeitos protetores (ANGELE et al., 2006; BREITHAUPT-FALOPPA et al., 2014; CHAUDRY et al., 2003; DEITCH et al., 2007; HILDEBRAND et al., 2006; KNÖFERL et al., 2002; RAJU; CHAUDRY, 2008; ZECKEY et al., 2011) ou deletérios (DIEBEL; LIBERATI, 2011; RAPPOLD et al., 2002; SPERRY et al., 2008) do estradiol. É possível que as diferenças possam ser decorrentes do momento em que o estradiol é administrado ou das diferentes concentrações utilizadas. Contudo, aparentemente os efeitos do estradiol (protetores/deletérios) parecem ser dependentes da fase em que a inflamação sistêmica decorrente do choque se encontra. Isto é, se em efeito agudo, este esteroide exerceria efeito protetor e deletério em fase mais tardia. 
É interessante notar que em um estudo envolvendo 991 pacientes internados em unidades de terapia intensiva (UTIs) dos quais, $75 \%$ eram homens, houve uma nítida correlação entre elevadas concentrações séricas de estradiol e morte decorrente de trauma (DOSSETT et al., 2008). Estes fatos reforçam a visão de que os efeitos do estradiol podem ser protetores ou lesivos, e fica evidenciado que apesar da compreensão de sua participação na resposta inflamatória após o trauma, ainda não se conhece com clareza os mecanismos reguladores desses efeitos.

Tomados em conjunto, os estudos da literatura indicam que o estradiol possa interferir no curso da resposta inflamatória e exercer importante efeito (positivo/negativo) na homeostasia. Todavia, ainda não existem dados conclusivos acerca do papel deste hormônio na inflamação causada pelo evento isquêmico intestinal. Considerando o intestino como a estrutura afetada diretamente pela isquemia e o primeiro a ser suprido pelo aporte sanguíneo após a reperfusão, neste estudo investigamos o efeito do estradiol no controle das repercussões intestinais induzidas pela IR intestinal com ênfase no momento de sua administração. 


\section{HIPÓTESE}

- O estradiol poderia ter efeito terapêutico ou preventivo sobre a inflamação intestinal e sistêmica, causada pela isquemia e reperfusão intestinal. 


\section{OBJETIVOS}

- Determinar as alterações funcionais e inflamatórias do intestino em ratos submetidos ao modelo experimental de isquemia e reperfusão intestinal.

- Investigar o efeito modulador do tratamento com estradiol nas consequências intestinais e sistêmicas nesse modelo. 


\section{MATERIAIS E MÉTODOS}

\subsection{Animais}

Foram utilizados ratos machos Wistar adultos (60 dias), com peso entre 160 e $180 \mathrm{~g}$, provenientes do Biotério Central do Instituto de Ciências Biomédicas da Universidade de São Paulo. Os animais foram mantidos em condições de temperatura e umidade controladas em ciclo claro/escuro de 12 h. Os ratos tiveram livre acesso à ração e água. Os estudos foram previamente aprovados pela Comissão de Ética no Uso de Animais do ICB/USP (111/2013).

\subsection{Indução de IR intestinal}

Os ratos foram anestesiados com cetamina/xilazina (i. p.; $100 \mathrm{mg} / \mathrm{kg}$ e $20 \mathrm{mg} / \mathrm{kg}$, respectivamente) e tramadol (5 mg/kg, i. p.) para a analgesia, antes da cirurgia. Após laparotomia mediana e evisceração, a AMS foi localizada e a isquemia intestinal realizada (45 min) com clamp cirúrgico metálico de acordo com Cavriani et al., (2004). Durante o período de manutenção da isquemia, o abdômen dos animais foi coberto com filme estirável de PVC $(15 \mathrm{~cm} \times 10 \mathrm{~cm})$ para minimizar perdas de líquido e calor. Ao fim da isquemia, o clamp foi retirado e a incisão mediana fechada com sutura contínua, em dois planos, com fio de algodão polifilamentar de 0,5 mm de espessura. Após $2 \mathrm{~h}$ de reperfusão intestinal os animais foram submetidos à eutanásia, sob anestesia profunda, por exsanguinação da aorta abdominal. Animais submetidos a manipulação similar ao grupo IR intestinal, mas sem a oclusão da AMS (Sham). Valores obtidos em animais não manipulados (Basais) foram utilizados como valores de referências.

\subsection{Tratamentos farmacológicos}

Grupos de ratos foram tratados 30 min após o início da isquemia $(280 \mu \mathrm{g} / \mathrm{kg}$, i. v.) ou 24 $\mathrm{h}$ antes da indução da isquemia intestinal com 17ß-estradiol $(280 \mu \mathrm{g} / \mathrm{kg}$, s. c.). A concentração utilizada foi baseada em estudos prévios (LIGEIRO DE OLIVEIRA et al., 2004). Além disso, os animais submetidos a IR intestinal e não tratados com estradiol receberam o veículo do 
estradiol hidrossolúvel (ciclodextrina), usado no tratamento de 30 min após a isquemia $(4,9$ $\mathrm{mg} / \mathrm{kg}$, i. v.).

\subsection{Determinação dos níveis séricos hormonais}

Após o término do período de 2 horas de reperfusão intestinal foram coletadas amostras de sangue da aorta abdominal para realização das dosagens de estradiol. As concentrações circulantes do hormônio foram determinadas utilizando kits de ELISA seguindo as instruções do fabricante (Cayman Chemical Company, USA).

\subsection{Estudo da permeabilidade vascular intestinal}

A avaliação da permeabilidade vascular foi feita por meio da técnica de determinação da concentração do corante azul de Evans (AE) extravasado no intestino (CAVRIANI et al., 2004). O corante foi injetado por via intravenosa 20 min antes do fim das $2 \mathrm{~h}$ de reperfusão intestinal $(25 \mathrm{mg} / \mathrm{kg})$. Fragmentos do duodeno foram removidos, limpos e pesados. Um deles foi colocado em formamida ( $4 \mathrm{~mL} / \mathrm{g}$ de peso tecidual, a temperatura ambiente por $24 \mathrm{~h}$ ), enquanto a outro foi mantida em estufa de secagem $\left(56^{\circ} \mathrm{C}\right)$ por $24 \mathrm{~h}$, para obtenção do peso seco. A densidade óptica foi obtida em leitor de ELISA (Bio-Tek Instruments®, USA) em comprimento de onda $620 \mathrm{~nm}$ e os valores de AE foram expressos em $\mu \mathrm{g}$ de AE/mg de peso de tecido.

\subsection{Estudo da permeabilidade da mucosa intestinal}

Grupos de ratos receberam no início da reperfusão $50 \mathrm{mg} / \mathrm{kg}$ da solução de dextran-FITC (4 kD, Sigma-Aldrich ${ }^{\circledR}$, EUA) diluídos em salina tamponada com fosfato (PBS), que foram injetados com seringa de tuberculina e agulha 0,38 x $13 \mathrm{~mm}$ cuidadosamente no lúmen do duodeno exposto. Ao final do período de reperfusão intestinal, amostras de soro foram obtidas e protegidas da luz e armazenadas em freezer $\left(-80^{\circ} \mathrm{C}\right)$ até a leitura por espectrofotometria de fluorescência $(495 \mathrm{~nm})$. A concentração de dextran-FITC nas amostras foi determinada com base em uma curva padrão, de 2000 - 0,24 ng/mL numa diluição 1:2. Esta técnica se baseia na quantificação de dextran-FITC que extravasa do lúmen do intestino para o sangue. 


\subsection{Estudo do recrutamento/ativação de neutrófilos no intestino}

A atividade da enzima MPO foi baseada na metodologia descrita por Goldblum et al., (1985). Fragmentos do duodeno foram removidos, pesados e congelados. Sendo depois homogeneizados em $3 \mathrm{~mL} / \mathrm{g}$ de tampão fosfato $\mathrm{pH}$ 6,0 contendo $0,5 \%$ de brometo de hexadecil-tri-metil-amônio (HTAB) e $5 \mathrm{mM}$ de ácido etilenodiamino tetra-acético (EDTA). Os homogenatos do duodeno foram então centrifugados a $12000 \mathrm{rpm}$ durante 15 min a $4{ }^{\circ} \mathrm{C}$, e o sobrenadante obtido utilizado para determinar a atividade de MPO. O ensaio da atividade de MPO foi conduzido adicionando a placas de 96 poços $10 \mu \mathrm{l}$ da amostra. Às amostras foram adicionados $200 \mu \mathrm{l}$ de substrato, contendo tampão fosfato ( $\mathrm{pH}$ 6), peróxido de hidrogênio $(0,1 \%)$ e orto-dianisidina $(1,25 \%)$. Decorridos 5 min, a reação foi paralisada pela adição de 50 $\mu 1$ de azida sódica (1\%). A leitura da absorbância foi feita em leitor de ELISA (Bio-Tek Instruments ${ }^{\circledR}$, EUA) em comprimento de onda de $450 \mathrm{~nm}$ e os valores expressos em atividade de MPO por mg de tecido.

\subsection{Estudo da motilidade intestinal}

Os animais receberam imediatamente antes do procedimento anestésico, por gavagem, o volume de $1 \mathrm{~mL}$ da suspensão de carvão ativo a 20\% (Lafan Quimica Fina Ltda, SP). Decorrido o período de IR intestinal, os animais foram submetidos a eutanásia e um segmento compreendido do piloro até o início do ceco foi removido para avaliação da distância percorrida pelo carvão (RUWART et al., 1980). A distância foi determinada do piloro até o ceco, ou seja, do intestino delgado, que contivesse pelo menos $1 \mathrm{~cm}$ contínuo de carvão. A distância foi calculada em relação ao comprimento total do intestino delgado e expressa em porcentagem.

\subsection{Estudo da reatividade de segmentos de íleo isolado}

Segmentos do íleo $(1-2 \mathrm{~cm})$ foram removidos e montados para registro isométrico de contrações em cubas para órgão isolado $(15 \mathrm{~mL})$ contendo solução de Krebs-Henseleit aerada com 95\% e 5\% $\mathrm{CO}_{2}$ com a seguinte composição (mM): $\mathrm{NaCl} 115,0 ; \mathrm{KCl} 4,6 ; \mathrm{CaCl}_{2} 2 \mathrm{H}_{2} 0$ 2,5; $\mathrm{KH}_{2} \mathrm{PO}_{4}$ 1,2; $\mathrm{MgSO}_{4} 7 \mathrm{H}_{2} \mathrm{O}$ 25; $\mathrm{NaHCO}_{3}, 25,0$ e glicose 11,0. Os segmentos de íleo foram submetidos a uma carga inicial de $1,0 \mathrm{~g}$ de tensão. Após a carga inicial o tecido foi 
mantido em repouso (60 min) para a estabilização, com troca do tampão a cada 15 minutos. Decorrido esse período, a tensão foi reajustada para 1,0 g e a viabilidade da preparação foi testada substituindo o tampão $\mathrm{KH}$ por $\mathrm{KCl}(60 \mathrm{mM})$. Após o período de equilíbrio (20 min) a curva concentração-efeito à metacolina foi construída $\left(10^{-6}\right.$ a $\left.10^{-3} \mathrm{M}\right)$.

\subsection{Coleta e análise do fluido/líquido intestinal obtido durante a IR intestinal}

Grupos de animais submetidos a IR intestinal tiveram seu intestino delgado e grosso envolvido e acondicionado em embalagem plástica $(9 \mathrm{~cm} \mathrm{X} 15 \mathrm{~cm})$ durante todo o período de isquemia e reperfusão (NARITA et al., 2004). Ao final da IR intestinal as embalagens foram removidas, o volume do fluido intestinal e seu conteúdo leucocitário foi quantificado. Para isso $20 \mu \mathrm{l}$ do líquido intestinal foram homogeneizados em diluente para determinação do número total e diferencial de leucócitos. As amostras foram analisadas em analisador hematológico (BC-2800vet, Mindray, China).

\subsection{Determinação dos níveis de IL-10 e TNF- $\alpha$ no fluido intestinal obtido durante a IR intestinal}

Amostras do líquido intestinal foram utilizadas para determinação dos níveis de IL-10 e TNF- $\alpha$ por meio de kit comercial (IL-10: Duo Set, R \& D System®, EUA; TNF- $\alpha$ : ELISA Ready-SET-Go! ®, eBioscience, EUA). Os ensaios foram conduzidos seguindo as especificações do fabricante e a densidade óptica obtida em leitor de ELISA (Bio-Tek Instruments $\left.{ }^{\circledR}, \mathrm{EUA}\right)$ em $450 \mathrm{~nm}$.

\subsection{Determinação número total e diferencial de leucócitos e do número de plaquetas circulantes}

Amostras de sangue $(20 \mu \mathrm{l})$ foram coletadas da cauda dos animais antes da indução da isquemia e após o término do período de reperfusão. Foi utilizada pipeta automática para coletar a amostra, que foram então homogeneizadas em diluente e submetidas à contagem automática de células, total e diferencial, em analisador hematológico (BC-2800vet, Mindray, China). 


\subsection{Determinação do número total de células na medula óssea}

Após o término do período de reperfusão intestinal os animais foram submetidos à eutanásia e o fêmur esquerdo foi cirurgicamente removido, ambas as extremidades foram abertas e o canal medular perfundido a partir da extremidade distal, pela introdução de uma agulha acoplada a uma seringa contendo $10 \mathrm{~mL}$ de PBS. As amostras foram centrifugadas durante 15 min a $15000 \mathrm{rpm}$, o "pellet" foi ressuspendido em 1mL de PBS. Alíquotas de $90 \mu \mathrm{l}$ da suspensão foram acrescidas de $10 \mu \mathrm{l}$ de cristal violeta $(0,2 \%)$, seguido de uma diluição de 1:10 em PBS. A quantificação do número de células foi realizada em câmara de Neubauer e expressas em $\times 10^{6}$ células $/ \mathrm{mL}$.

\subsection{Ensaio de quimiotaxia in vitro com neutrófilos do sangue}

$\mathrm{O}$ volume de sangue $(5 \mathrm{~mL})$ foi coletado de animais anestesiados pela artéria aorta abdominal com auxílio de seringa plástica $(5 \mathrm{~mL})$ e agulha $(0,8 \times 25 \mathrm{~mm})$ contendo citrato (Citrate concentrated solution, Sigma-Aldrich®, EUA). Os neutrófilos foram separados por centrifugação em gradiente de Ficoll:Hipaque (Histopaque, Sigma-Aldrich®, EUA) com metodologia baseada em Newman et al. (1982). Para tanto, em um tubo plástico $(15 \mathrm{~mL})$ foram colocados $5 \mathrm{~mL}$ de Histopaque e $5 \mathrm{~mL}$ de sangue total misturado em proporção 1:1 com PBS, evitando-se a mistura das fases. Em seguida o tubo foi centrifugado a 1300 rpm por $50 \mathrm{~min}$, à temperatura ambiente. O plasma, as células mononucleares e o Histopaque foram descartados. No tubo contendo neutrófilos e hemácias foram adicionados $2 \mathrm{~mL}$ de dextran (6\%), homogeneizados por inversão e incubados por $1 \mathrm{~h} \mathrm{a} 37^{\circ} \mathrm{C}$ com o tubo inclinado $\left(45^{\circ}\right)$. O sobrenadante contendo os neutrófilos foi recolhido e centrifugado a $1200 \mathrm{rpm}$ por $10 \mathrm{~min}$. Ao "pellet", contendo neutrófilos e hemácias, foi adicionado cloreto de amônia, para lise destas últimas, e novamente centrifugado. Os neutrófilos foram então ressuspendidos em meio de cultura (RPMI, Sigma-Aldrich®, EUA), contados e preparados para ensaio de quimiotaxia in vitro, acertando o volume para $2 \times 10^{6} / \mathrm{mL}$. O ensaio de quimiotaxia se baseia na migração de células através de um filtro poroso. Para o ensaio foi utilizada uma placa de quimiotaxia da ChemoTx® System (Neuro Probe, Inc., EUA), contendo 96 poços e uma placa com filtro de câmara (com poros de $3 \mu \mathrm{m}$ ), dessa forma a metodologia foi feita com base em Riffo-Vasquez et al. (2014). A placa de quimiotaxia foi bloqueada por 1 hora com $30 \mu \mathrm{de}$ RMPI contendo $1 \%$ de BSA. Decorrido o tempo desejado a placa foi invertida em papel absorvente pra remoção do meio de bloqueio e adicionado $30 \mu 1$ de RPMI em cada poço da 
microplaca. Na sequência, o filtro foi posicionado acima da placa e adicionados $20 \mu \mathrm{l}$ da solução contendo $4 \times 10^{4}$ neutrófilos foram adicionados sobre o sitio hidrofílico do filtro. Após tampada, a placa com filtro foi colocada na estufa $\left(37^{\circ} \mathrm{C}\right)$ e incubada por $90 \mathrm{~min}$. O filtro foi então removido e $20 \mu \mathrm{l}$ da suspensão de neutrófilos em RPMI contida em cada poço da microplaca foram diluídos com cristal violeta $(1: 1)$ e a contagem de células efetuadas em câmara de Neubauer com microscópio óptico comum.

\subsection{Determinação da atividade sérica de fosfatase alcalina e lactato desidrogenase}

Alíquotas de $10 \mu \mathrm{L}$ de soro obtidas a partir das amostras de sangue dos animais foram adicionadas a placas de 96 poços. As determinações foram realizadas utilizando kit comercial de fosfatase alcalina Bioclin ${ }^{\circledR}$ (Quiobasa Química Básica Ltda., Brasil) e kit comercial desidrogenase lática (LDH) UV Bioclin ${ }^{\circledR}$ (Quiobasa Química Básica Ltda., Brasil), seguindo as instruções do fabricante.

\subsection{Determinação dos níveis de mediadores inflamatórios no soro}

A quantificação dos níveis de fator estimulador de colônias de granulócitos e macrófagos (GM-CSF), proteína inflamatória de macrófagos-1 $\alpha$ (MIP-1 $\alpha$ ), interleucina-1 $\beta$ (IL-1 $)$, interleucina-6 (IL-6), interleucina-10 (IL-10), interleucina-12p70 (IL-12p70), interferon- $\gamma($ IFN- $\gamma$ ), interleucina-17 (IL-17), proteína quimiotática de monócitos-1 (MCP-1), proteína induzida pelo IFN- $\gamma-10$ (IP-10), oncogene relacionado ao crescimento/quimiotáxico de queratinócitos (GRO/KC), fator de crescimento endotelial vascular (VEGF) e fator de necrose tumoral- $\alpha($ TNF- $\alpha)$ ) foi realizada com a utilização de kit comercial Milliplex ${ }^{\circledR}$ (Merck Millipore, EUA). As amostram foram enviadas para o Instituto Genesis de Análises Científicas onde os ensaios foram conduzidos seguindo as especificações do fabricante e a leitura foi realizada com o equipamento Luminex 200 - Software xPonent/Analyst versão 4.2.

\subsection{Análise estatística}

As análises estatísticas, escolhidas de acordo com o desenho experimental, foram conduzidas utilizando GraphPad Prism 5.0. Os dados obtidos foram expressos como média \pm EPM. Foi utilizado ANOVA de uma via seguido de teste de Bonferroni em todos os dados, 
exceto para as análises do leucograma, onde utilizamos ANOVA duas vias seguido de teste Bonferroni. Assim como nas análises da área sob a curva (area under the curve - AUC), que foram realizadas com ANOVA uma via seguido de teste de Bonferroni. Valores de $\mathrm{P}<0.05$ foram considerados significativos. 


\section{RESULTADOS}

\subsection{Determinação da concentração de estradiol no soro de animais tratados}

A tabela 1 representa a concentração sérica de estradiol em ratos machos tratados com estradiol 30 min após a isquemia (E30 - $280 \mu \mathrm{g} / \mathrm{kg}$, i. v.) ou 24 horas antes da isquemia (E24 - $280 \mu \mathrm{g} / \mathrm{kg}$, s. c.). As concentrações desse esteroide após os tratamentos aumentaram em relação ao valor controle. Observa-se que o tratamento dos animais $30 \mathrm{~min}$ antes da indução da isquemia elevou a concentração em relação ao grupo IR tratado com o veículo do estradiol. Já o tratamento dos animais $24 \mathrm{~h}$ antes da indução da isquemia resultou em concentração superior à dos animais IR intestinal não tratados, contudo muito menores do que a observada nos animais tratados com estradiol após 30 min de isquemia. 
Tabela 1 - Concentração sérica de estradiol (pg/mL) de ratos submetidos à isquemia (45 min) e reperfusão intestinal (2 horas - IR intestinal). Havendo dois tratamentos com 17ß-estradiol um após $30 \mathrm{~min}$ do início da isquemia (E30 - $280 \mu \mathrm{g} / \mathrm{kg}$, i. v.) e $24 \mathrm{~h}$ antes da isquemia (E24 $280 \mu \mathrm{g} / \mathrm{kg}$, s. c.).

\begin{tabular}{cc}
\hline Grupos & Estrógeno \\
\hline IR & $94,81 \pm 14,46$ \\
E30 & $17904 \pm 3652 \gamma$ \\
E24 & $212,4 \pm 25,49$ \\
\hline
\end{tabular}

Os dados representam a média \pm EPM de 6 experimentos. ${ }^{\gamma} \mathrm{P}<0,05$ em relação ao grupo IR intestinal. 


\subsection{Efeito da IR intestinal e do tratamento dos animais com estradiol sobre o aumento da permeabilidade vascular no intestino}

Podemos observar no gráfico 1 (Painel A) o aumento significativo do extravasamento do corante azul de Evans no grupo submetido a IR intestinal, quando comparado ao grupo falsamente submetido à IR intestinal (Sham) e não manipulado (Basal). Além disso, no painel B do gráfico 1 é possível notar que os animais tratados com estradiol 30 min após a indução da isquemia (E30) não apresentaram alteração significativa da permeabilidade vascular intestinal em relação aos animais não tratados.

Em contraste, o tratamento dos animais $24 \mathrm{~h}$ antes da IR intestinal foi eficaz em prevenir de forma significativa o aumento do extravasamento de corante, em relação ao grupo não tratado com estradiol (IR), chegando próximo aos níveis basais. 
Gráfico 1 - Extravasamento do corante azul de Evans (AE) no intestino de ratos submetidos à isquemia (45 min) e reperfusão intestinal (2 horas - IR intestinal). Os grupos consistiram de animais tratados com estradiol 30 min após ou 24 h antes da indução da isquemia, falsamente submetidos a IR intestinal (Sham) e animais não manipulados (Basal). Os dados representam a média \pm EPM de 8-12 experimentos. ${ }^{\phi} \mathrm{P}<0,05$ em relação ao grupo Basal; $* P<0,05$ em relação ao grupo Sham; ${ }^{\gamma} \mathrm{P}<0,05$ em relação ao grupo IR intestinal.
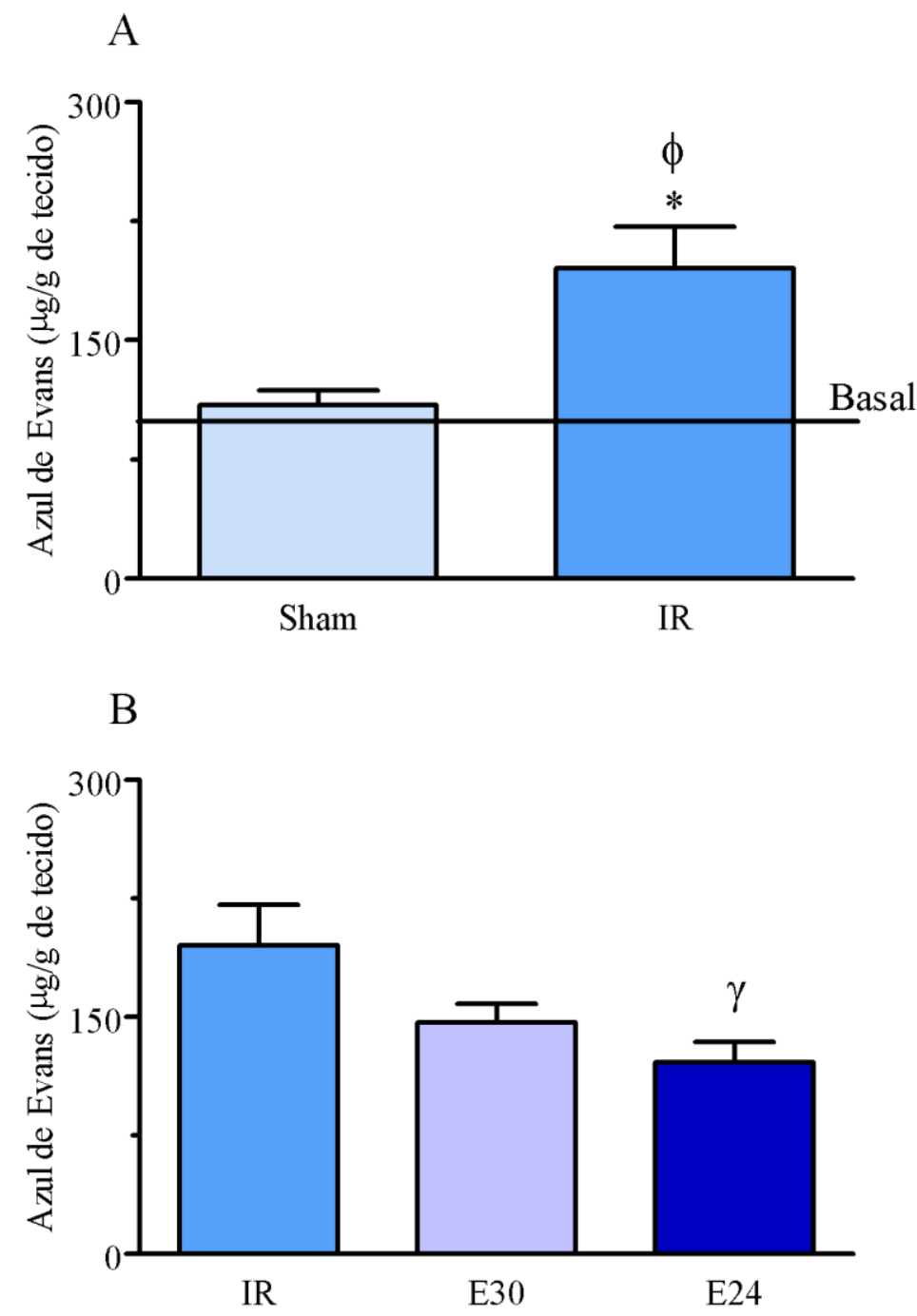


\subsection{IR intestinal e o tratamento dos animais com estradiol no aumento da permeabilidade da mucosa intestinal}

A avaliação da permeabilidade macromolecular intestinal foi realizada por meio do extravasamento de dextran-FITC do lúmen do duodeno dos animais para a circulação dos animais submetidos à IR intestinal. No gráfico 2 (Painel A) é possível notar que em animais falsamente operados (Sham), a permeabilidade da mucosa é baixa e que após a IR intestinal houve aumento significativo da concentração de dextran-FITC no soro dos animais, sugerindo o aumento da permeabilidade da mucosa intestinal.

O painel B do gráfico 2 representa o efeito dos tratamentos dos animais com estradiol (E30 e E24) sobre a permeabilidade da mucosa. Como pode ser observado apenas o tratamento dos animais com estradiol $30 \mathrm{~min}$ após a indução da isquemia diminuiu o significativamente a concentração de dextran-FITC quantificada no soro dos animais. 
Gráfico 2 - Permeabilidade do intestino de ratos submetidos à isquemia (45 min) e reperfusão intestinal (2 horas - IR intestinal) ao Dextran-FITC. Os grupos consistiram de animais tratados com estradiol $30 \mathrm{~min}$ após ou $24 \mathrm{~h}$ antes da indução da isquemia e falsamente submetidos a IR intestinal (Sham). Os dados representam a média \pm EPM de 4-7 experimentos. ${ }^{*} P<0,05$ em relação ao grupo Sham; ${ }^{\gamma} \mathrm{P}<0,05$ em relação ao grupo IR intestinal.
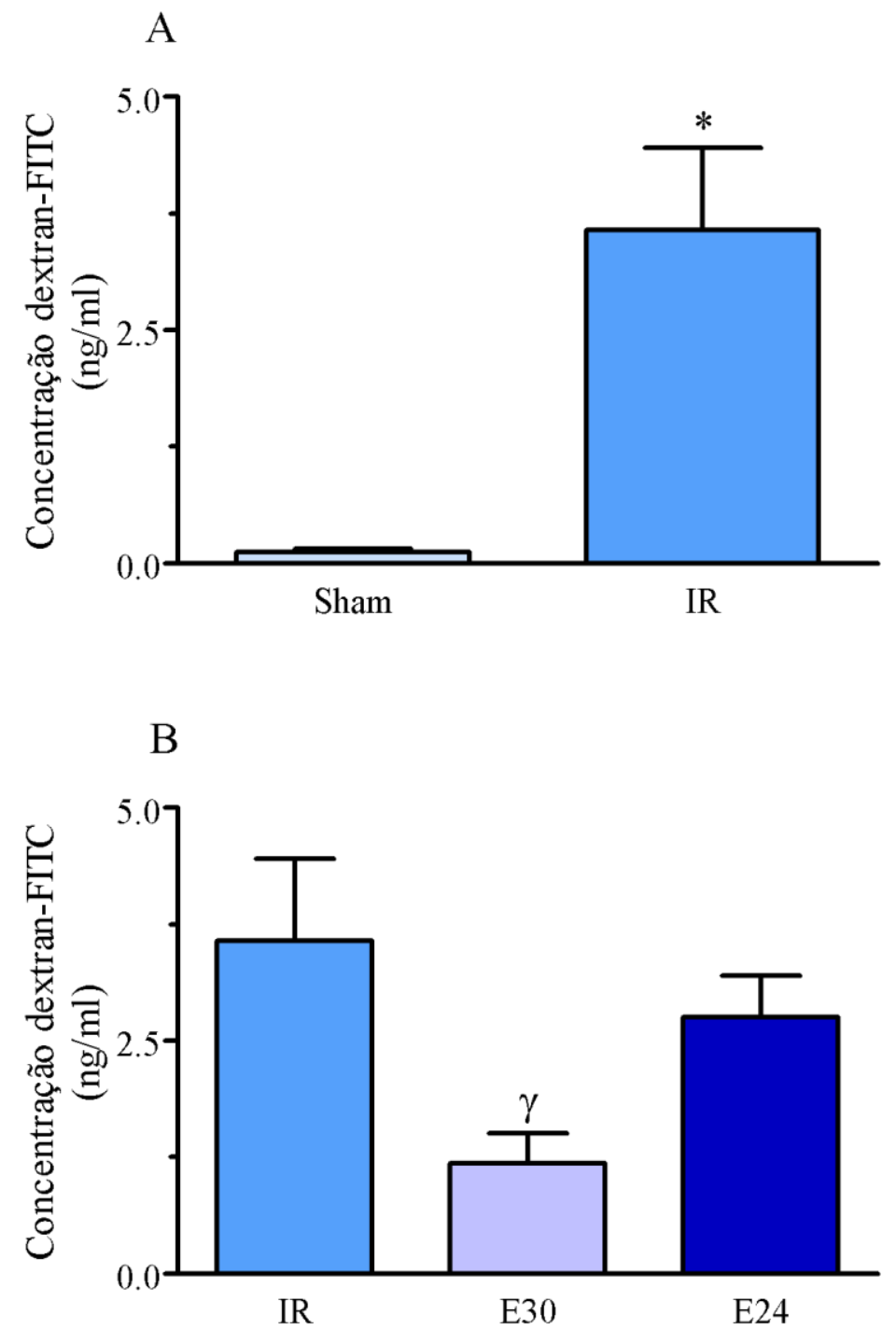


\subsection{Efeito da IR intestinal e do tratamento dos animais com estradiol sobre a atividade} da enzima mieloperoxidase no intestino

O grafico 3 representa o recrutamento/ativação de neutrófilos para o intestino causado pela IR intestinal. Os dados foram obtidos por meio da quantificação da atividade da enzima mieloperoxidase (MPO) em homogenatos de duodeno dos animais. No painel A do gráfico 3 observamos que houve um aumento significativo na atividade da MPO no duodeno dos animais submetidos à IR intestinal em relação à quantificada no grupo falsamente operado (Sham). Já no painel B do gráfico 3 observa-se que o tratamento dos animais com estradiol, 30 min após a indução da isquemia (E30) ou 24 h antes da sua indução (E24), não alterou de forma significativa a atividade de MPO no duodeno causada pela IR intestinal. 
Gráfico 3 - Valores de atividade da enzima mieloperoxidase (MPO) em homogenatos de duodeno de ratos submetidos à isquemia $(45 \mathrm{~min})$ e reperfusão intestinal (2 horas - IR intestinal). Os grupos consistiram também de animais tratados com estradiol 30 min após ou $24 \mathrm{~h}$ antes da indução da isquemia, falsamente submetidos a IR intestinal (Sham) e animais não manipulados (Basal). Os dados representam a média \pm EPM de 5-8 experimentos. $* P<0,05$ em relação ao grupo Sham.

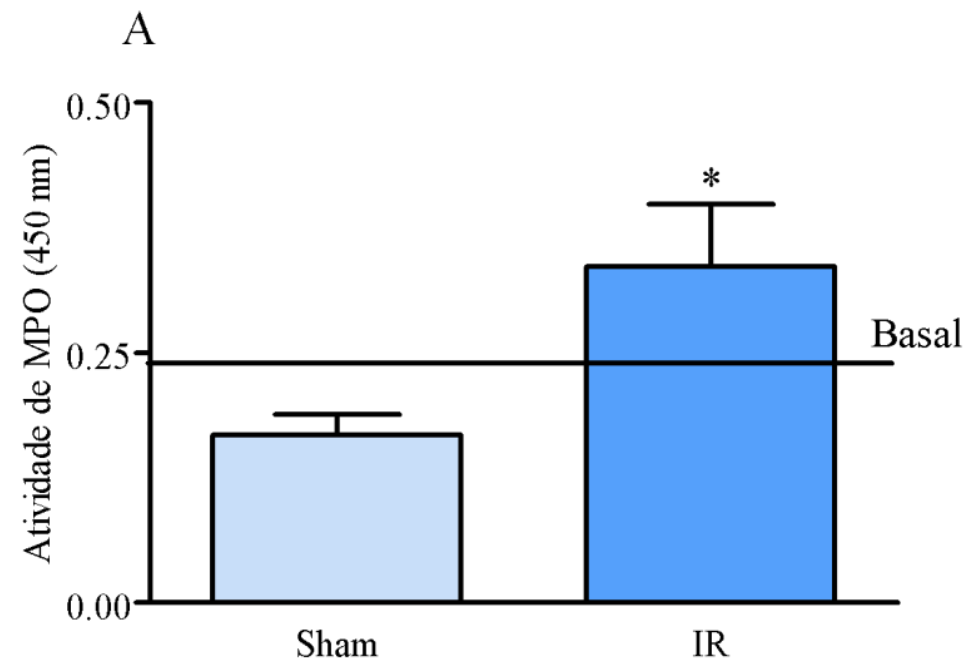

$\mathrm{B}$

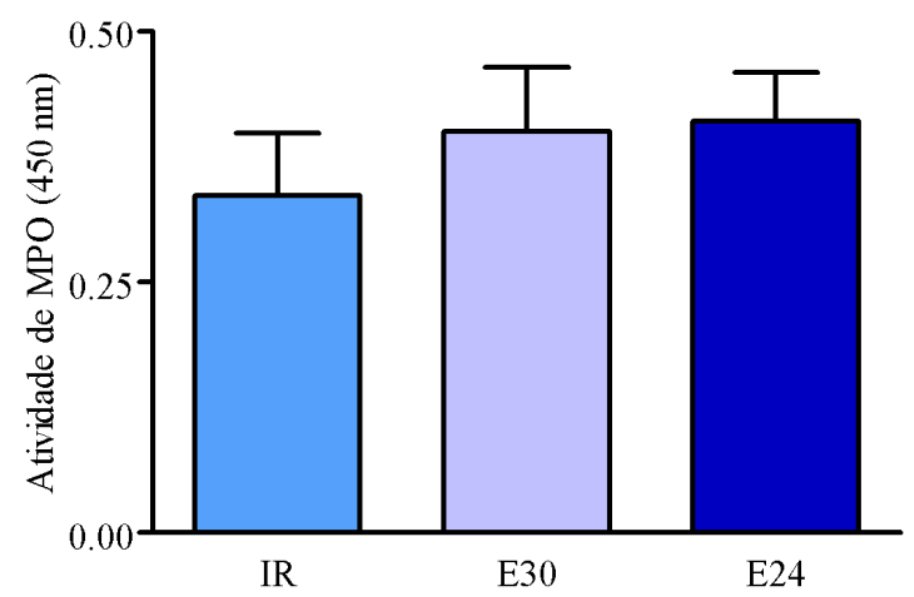




\subsection{Repercussão da IR intestinal e efeito do tratamento dos animais com o estradiol no trânsito intestinal}

O estudo do trânsito intestinal foi realizado para indicar a capacidade do intestino de impulsionar seu conteúdo na direção aboral, representando indiretamente a motilidade intestinal. Gráfico 4, painel A, observamos que a IR intestinal causou significativa redução do trânsito intestinal quando comparada ao determinado nos animais do grupo Sham. Ainda, foi observado que o trânsito intestinal dos animais do grupo Sham reduziu de forma significativa em relação ao observado no grupo Basal.

Com relação ao efeito do tratamento dos animais com estradiol (painel B do gráfico 4) observa-se que os animais do grupo IR intestinal tratados com estradiol $24 \mathrm{~h}$ antes da indução da isquemia (E24), apresentaram aumento da motilidade intestinal em relação aos animais IR intestinal não tratados (IR). Contudo, o tratamento com estradiol 30 min após a indução da isquemia (E30) resultou em apenas uma tendência de aumento do trânsito intestinal. 
Gráfico 4 - Porcentagem, em relação ao comprimento total do intestino delgado, de trânsito do carvão ativado (20\%), administrado antes dos ratos serem submetidos à IR intestinal. Os grupos consistiram de animais tratados com estradiol 30 min após ou 24 h antes da indução da isquemia, falsamente submetidos a IR intestinal (Sham) e animais não manipulados (Basal). Os dados representam a média \pm EPM de 5-9 experimentos. ${ }^{\mu} \mathrm{P}<0,05$ em relação ao grupo Basal; ${ }^{\phi} \mathrm{P}<0,05$ em relação ao grupo Basal; ${ }^{*} \mathrm{P}<0,05$ em relação ao grupo Sham; ${ }^{\gamma} \mathrm{P}<0,05$ em relação ao grupo IR intestinal.
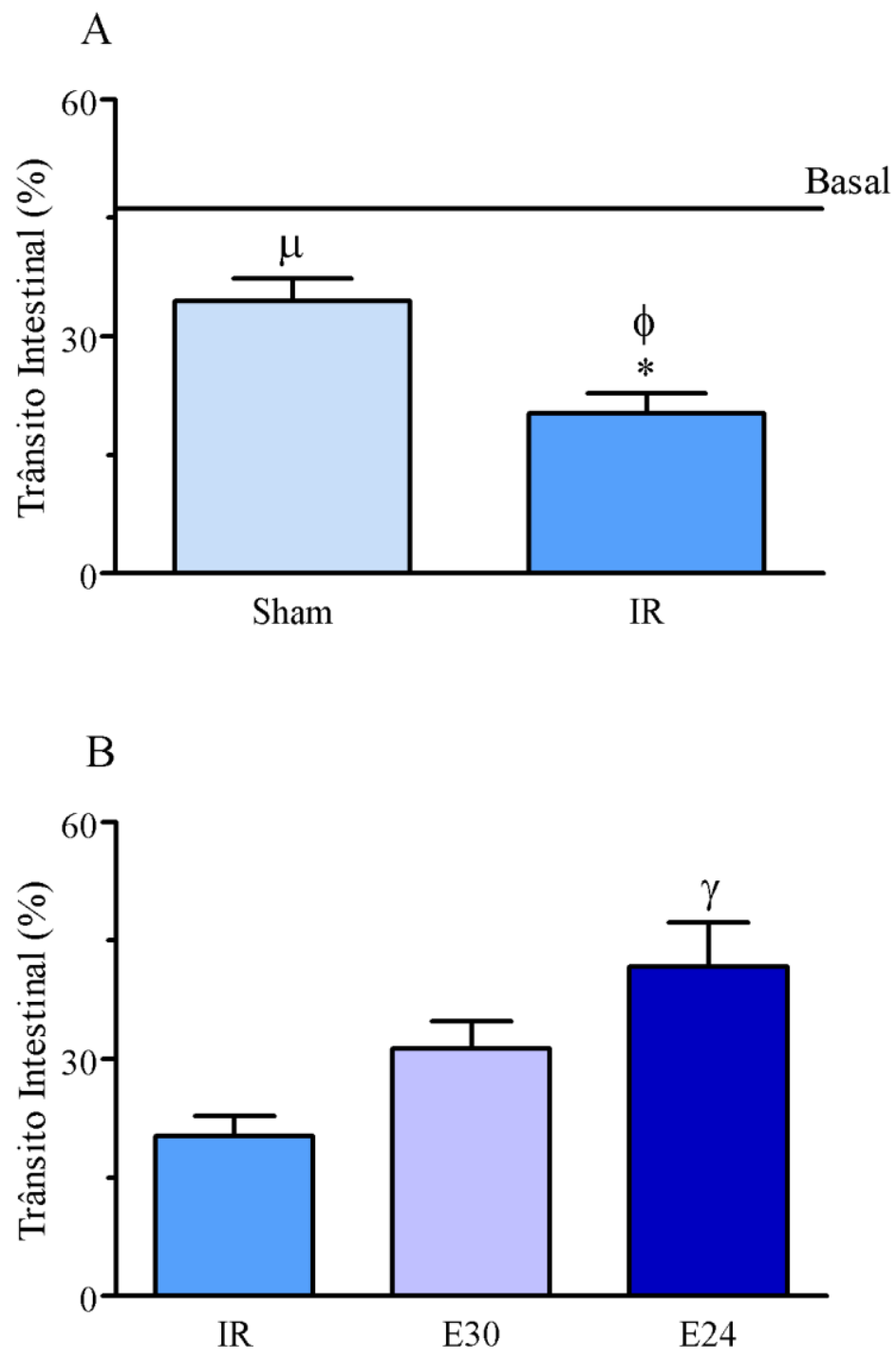


\subsection{Influência da IR intestinal e do tratamento dos animais com estradiol na reatividade à metacolina de segmentos de íleo isolado}

Continuando os estudos da funcionalidade do intestino após a IR intestinal também estudamos a resposta contrátil de segmentos do íleo frente ao estímulo de metacolina $\left(10^{-6} \mathrm{a}\right.$ $10^{-3} \mathrm{M}$ ). Primeiramente no gráfico 5 apresentamos os resultados da verificação da viabilidade dos segmentos de íleo após a despolarização com solução de $\mathrm{KCl}(60 \mathrm{mM})$. Nossos resultados mostram que todos os segmentos de íleo desenvolveram resposta contrátil ao $\mathrm{KCl}$ de magnitude similar.

A seguir (gráfico 6, painel A) estão representadas as curvas dose-resposta dos segmentos de íleo à metacolina dos animais submetidos a IR intestinal (IR) e dos grupos controles (Basal e Sham). No painel B observamos a análise da área sob a curva (area under the curve - AUC) correspondentes aos grupos do painel A. Como pode ser observado no painel A há tendência de que o íleo isolado do grupo IR apresente menor reatividade à metacolina, notadamente nas concentrações entre $10^{-5} \mathrm{M}$ e $10^{-4} \mathrm{M}$, quando comparada com a reatividade observada nos segmentos de íleo isolados dos animais do grupo Basal e Sham. Confirmando estes resultados os dados do painel B do gráfico 6 mostram diminuição da AUC nos animais do grupo IR, em relação ao grupo Sham.

Com respeito as curvas dose-resposta ao tratamento dos animais com estradiol, $30 \mathrm{~min}$ após a indução da isquemia (E30) ou 24 h antes da indução da isquemia (E24), observamos no painel C do gráfico 6 que não houve diferença entre os grupos investigados. Da mesma forma, notamos que nenhum dos períodos de tratamento com estradiol (E30 e E24) mostrou diferença da AUC. 
Gráfico 5 - Resposta contrátil ao $\mathrm{KCl}$ de segmentos de íleo in vitro de ratos submetidos à isquemia (45 min) e reperfusão intestinal (2 horas - IR intestinal). Os grupos consistiram de animais tratados com estradiol 30 min após ou 24 h antes da indução da isquemia, falsamente submetidos a IR intestinal (Sham) e animais não manipulados (Basal). Os dados representam a média \pm EPM de 7-11 experimentos.
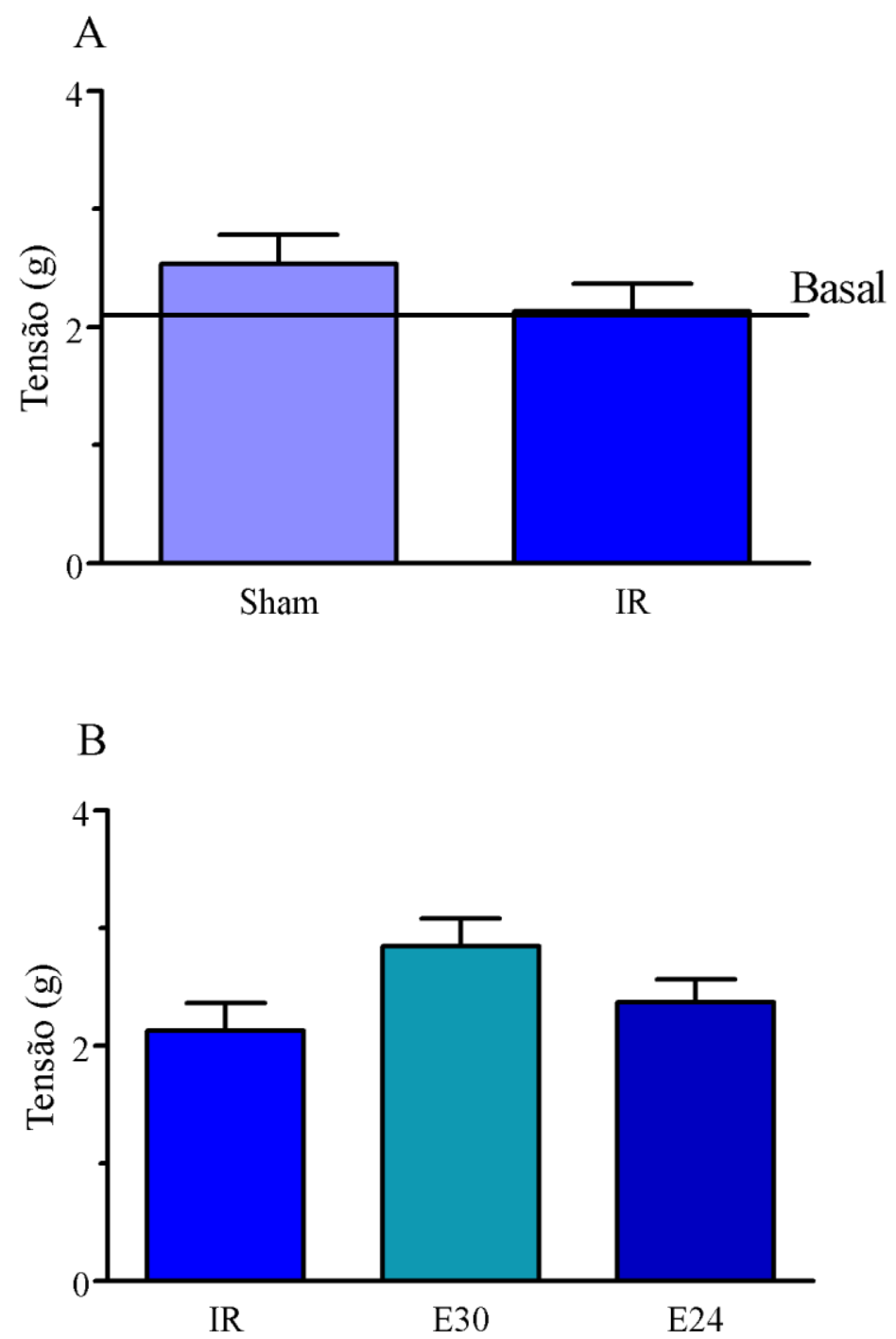
Gráfico 6 - Reatividade de íleo isolado de ratos submetidos à IR intestinal (Painel A e C) e a área sob a curva (area under the curve - AUC) dessas curvas de dose-resposta (Painel B e D). Os grupos também consistiram de animais tratados com estradiol (30 min após ou 24 h antes da indução da isquemia), falsamente submetidos a IR intestinal (Sham) e animais não manipulados (Basal). Os dados representam a média \pm EPM de 7-12 experimentos. ${ }^{*} \mathrm{P}<0,05$ em relação ao grupo Sham.
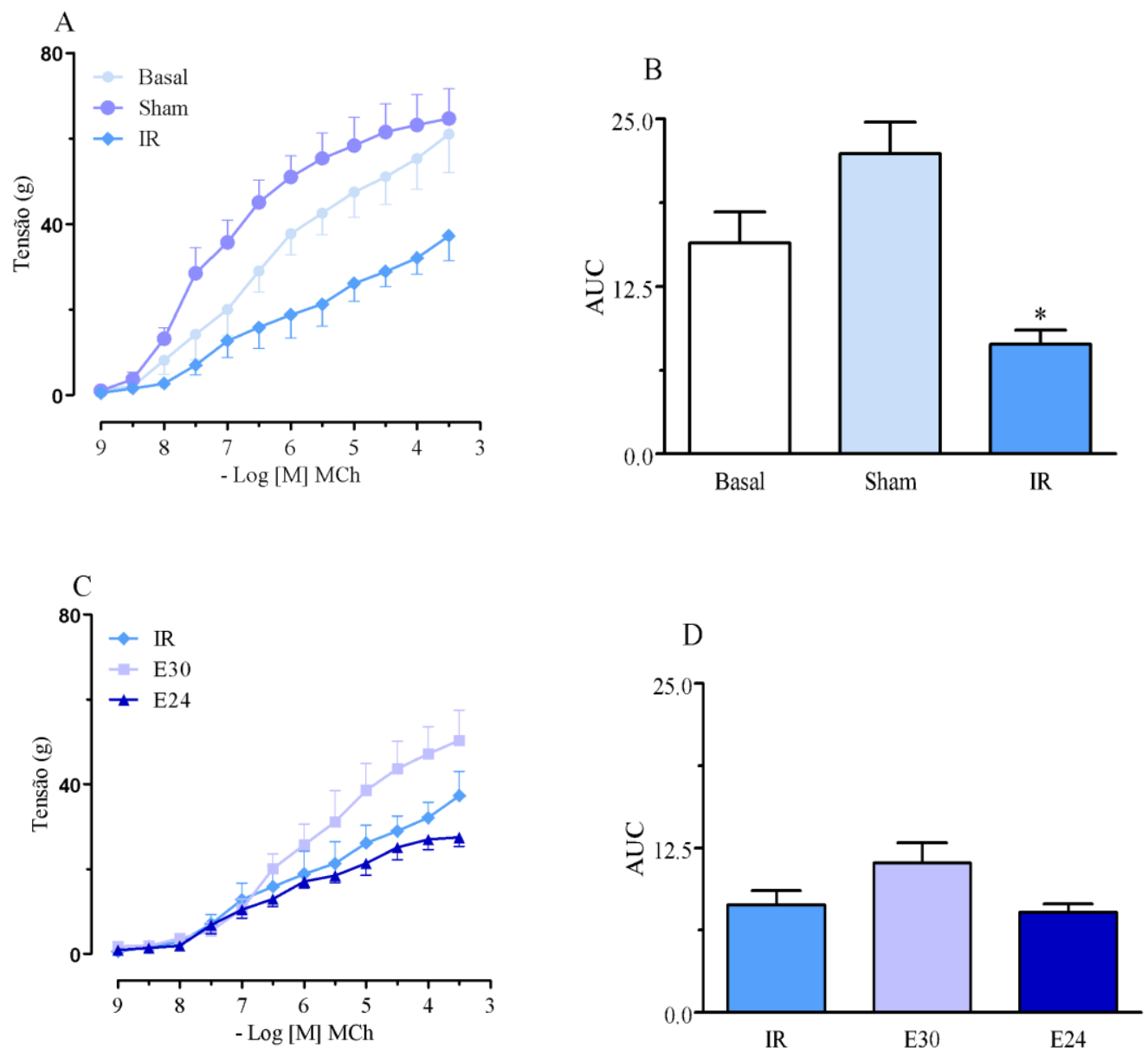
5.7 Efeito da IR intestinal e do tratamento dos animais com estradiol sobre o líquido intestinal produzido

O gráfico 7 mostra os valores de volume de líquido intestinal recuperado nas embalagens plásticas, as quais foram usadas para acondicionar o intestino dos animais durante todo o período de IR intestinal. Como pode ser observado no painel A, a IR intestinal causou significativa redução do líquido intestinal. No painel B é possível notar que o tratamento dos animais com estradiol em ambos os períodos (E30 e E24) não interferiu com volume recuperado de líquido intestinal. 
Gráfico 7 - Volume de fluido intestinal recuperado após o isolamento do intestino em embalagem plástica de ratos submetidosa IR intestinal.. Os grupos também consistiram de animais tratados com estradiol 30 min após ou 24 h antes da indução da isquemia e como controle animais falsamente submetidos a IR intestinal (Sham). Os dados representam a média \pm EPM de 5-6 experimentos. $* P<0,05$ em relação ao grupo Sham.
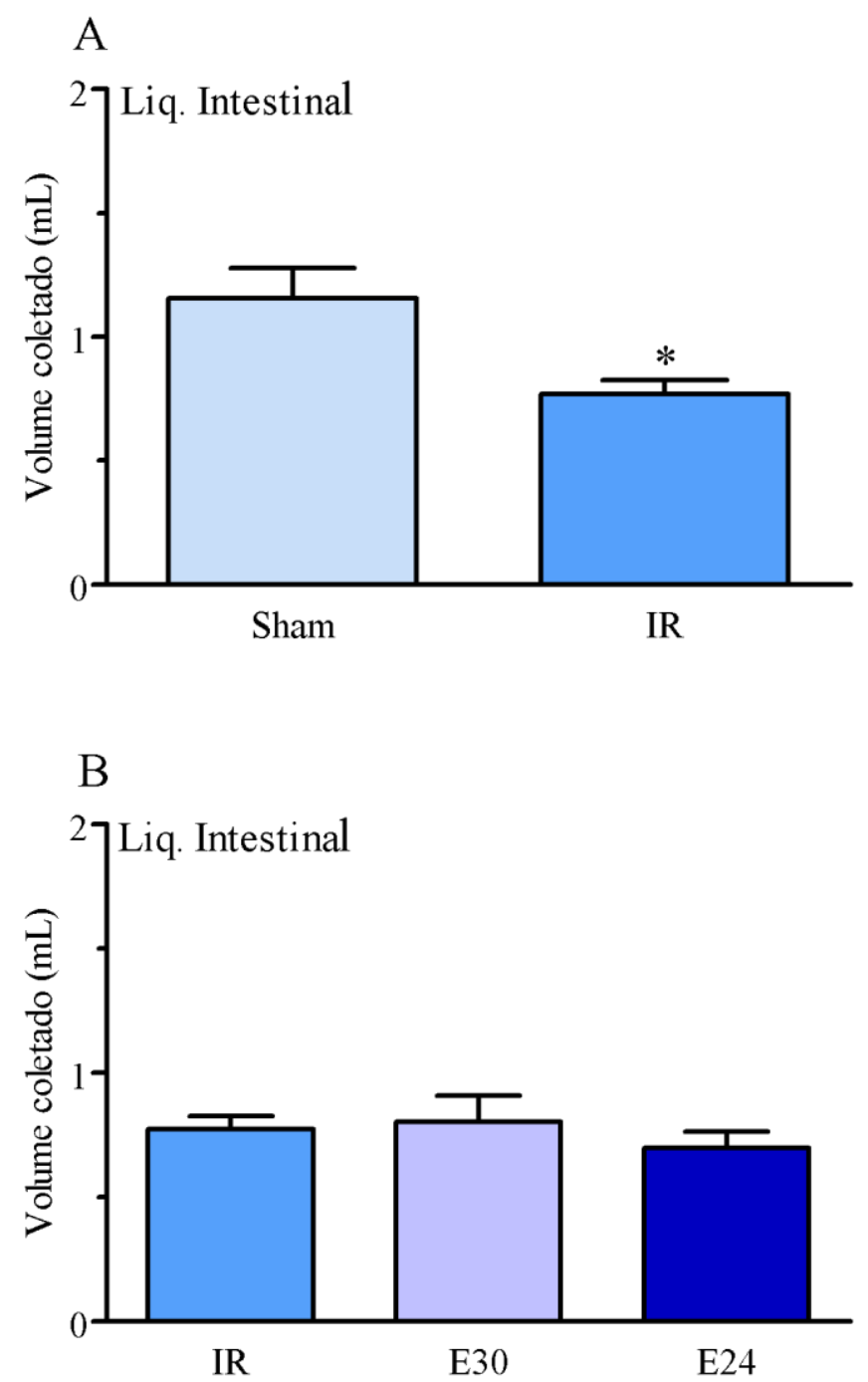
Dando continuidade aos estudos do fluido intestinal coletado quantificamos o corante AE presente no líquido intestinal. Para tanto, os animais receberam o corante AE nas condições descritas no item 4.5 dos Materiais e Métodos. Como pode ser observado no gráfico 8 não houve diferença no extravasamento do corante entre os animais submetidos à IR intestinal (IR) e falsamente operados (Painel A). Contudo, observando o painel B do gráfico 8 notamos que em relação ao grupo IR o tratamento dos animais com estradiol $24 \mathrm{~h}$ antes da indução da isquemia (E24) houve uma redução do extravasamento de corante AE. Resultado que não foi observado nos animais tratados com estradiol 30 min após o início da isquemia intestinal (E30). 
Gráfico 8 - Concentração de azul de Evans (AE) presente no fluido intestinal recuperado na embalagem plástica de ratos submetidos à IR intestinal. Os grupos consistiram também de animais tratados com estradiol 30 min após ou 24 h antes da indução da isquemia e como controle animais falsamente submetidos a IR intestinal (Sham). Os dados representam a média \pm EPM de 6-7 experimentos. ${ }^{\gamma} \mathrm{P}<0,05$ em relação ao grupo IR intestinal.
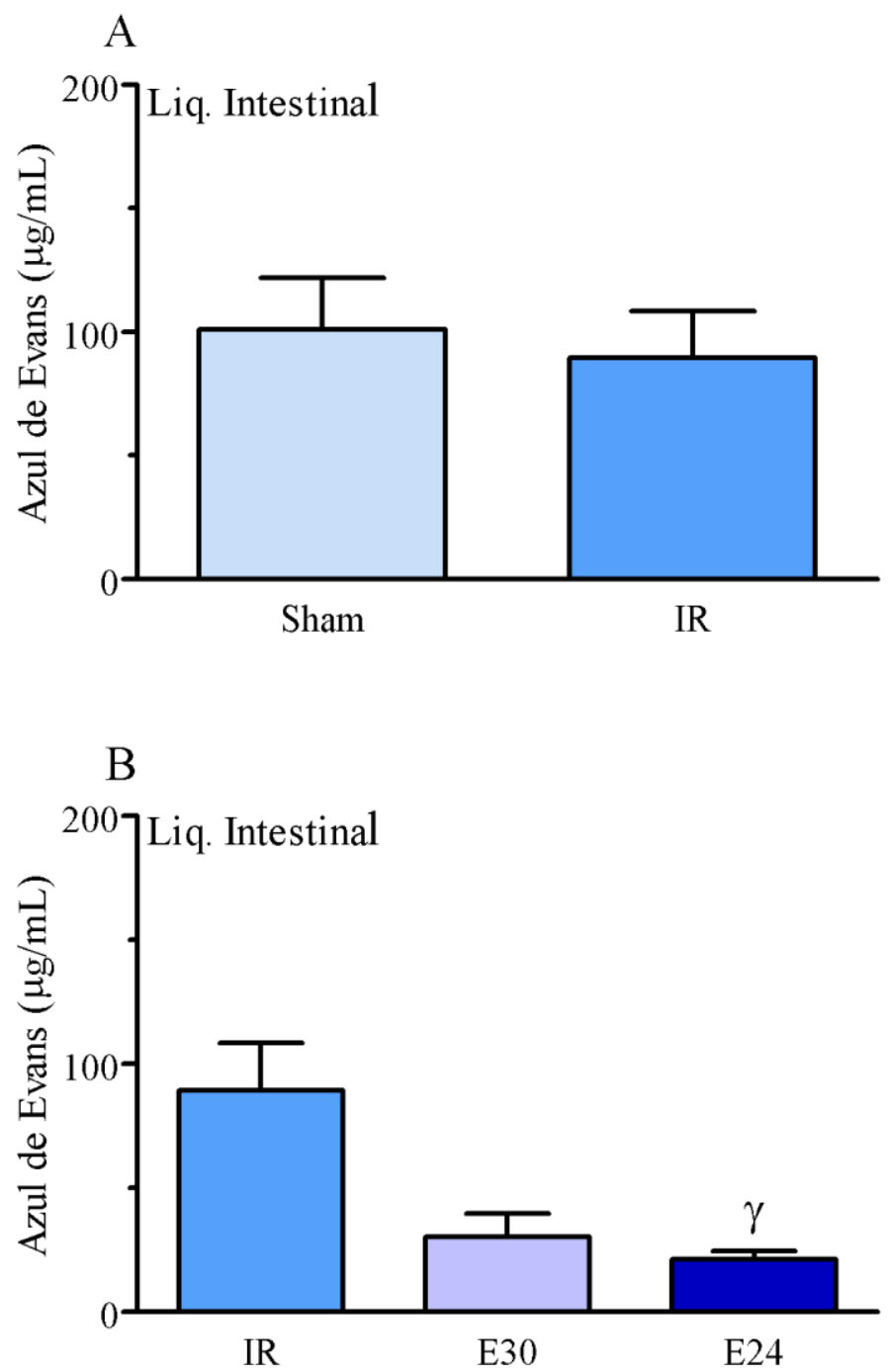
Em outra análise quantificamos a concentração de IL-10 e TNF- $\alpha$ no líquido intestinal recuperado das embalagens plásticas onde o intestino foi acondicionado. No gráfico 9 observamos o aumento de IL-10 no fluido intestinal dos animais submetidos à IR intestinal (IR) em comparação ao quantificado nos animais do grupo falsamente operado (Sham). Por outro lado, os animais tratados com estradiol, em ambos os períodos (E30 e E24), não alteraram os seus perfis de liberação desta citocina. Apesar de o estradiol administrado $24 \mathrm{~h}$ antes da isquemia (E24) reduzir a concentração de IL-10 no líquido intestinal, esta não se mostrou significativa. 
Gráfico 9 - Concentração de IL-10 no líquido intestinal recuperado da embalagem plástica de ratos submetidos à IR intestinal. Os grupos também consistiram de animais tratados com estradiol $30 \mathrm{~min}$ após ou $24 \mathrm{~h}$ antes da indução da isquemia e como controle animais falsamente submetidos a IR intestinal (Sham). Os dados representam a média \pm EPM de 3-7 experimentos. $* P<0,05$ em relação ao grupo Sham.
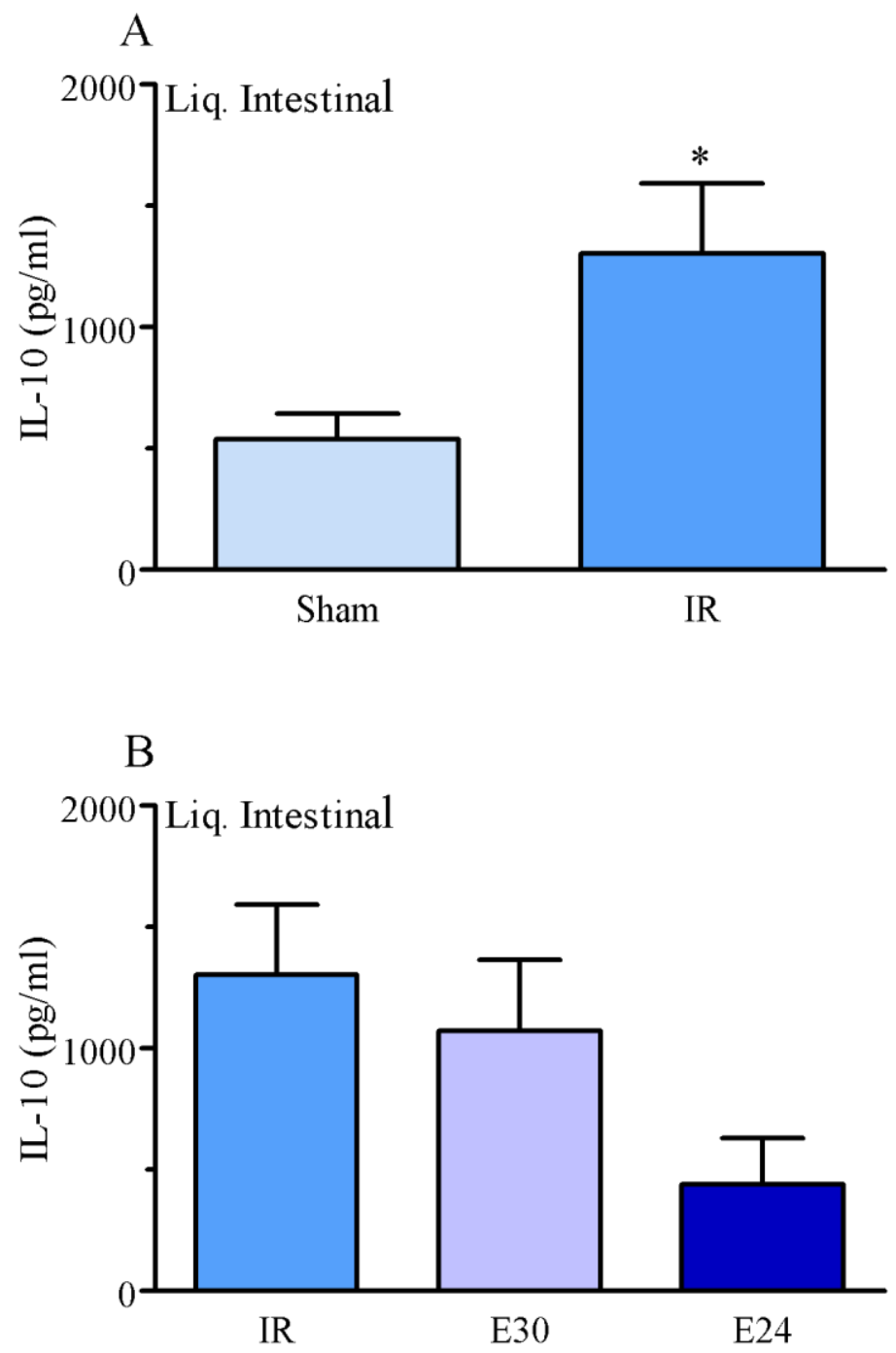
Como mencionado, quantificamos a concentração de TNF- $\alpha$ no fluido intestinal. Os dados estão representados no gráfico 10 e indicam o aumento desta citocina no liquido intestinal recuperado após a IR intestinal, em comparação ao observado no líquido de animais falsamente operados (Sham). No painel B do gráfico 10, observa-se que o tratamento dos animais com estradiol preveniu o aumento da concentração de TNF- $\alpha$ nos dois protocolos estudados (E30 e E24). 
Gráfico 10 - Concentração de TNF- $\alpha$ no líquido intestinal recuperado da embalagem plástica de ratos submetidos à IR intestinal. Os grupos também consistiram de animais tratados com estradiol $30 \mathrm{~min}$ após ou $24 \mathrm{~h}$ antes da indução da isquemia e como controle animais falsamente submetidos a IR intestinal (Sham). Os dados representam a média \pm EPM de 9-10 experimentos. ${ }^{*} P<0,05$ em relação ao grupo Sham; ${ }^{\gamma} \mathrm{P}<0,05$ em relação ao grupo IR intestinal.
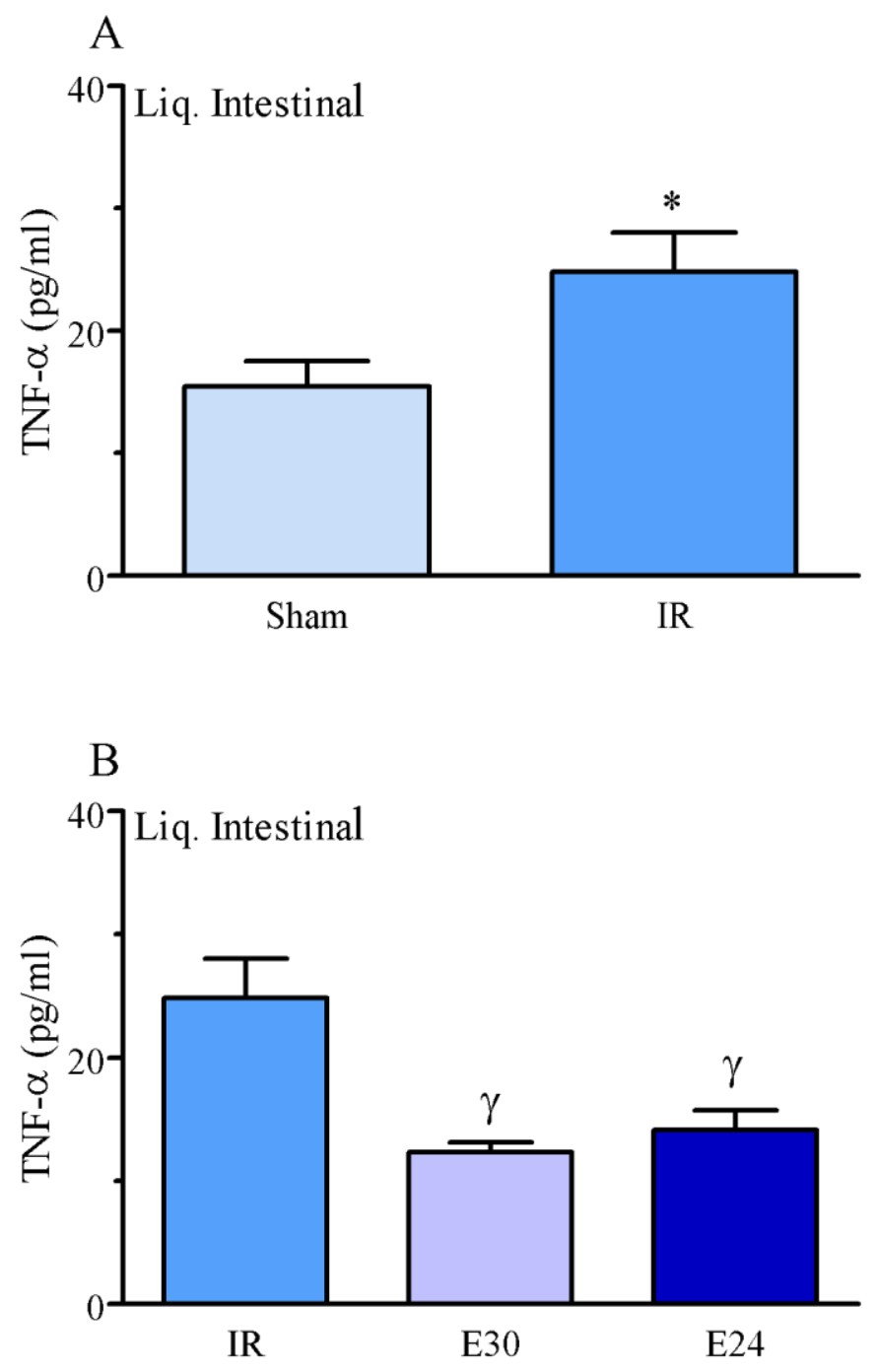
Uma vez investigada a presença de citocinas avaliamos o número de leucócitos presentes no líquido recuperado após o acondicionamento do intestino dos animais nas embalagens plásticas. Os dados obtidos estão representados na tabela 2. Como pode ser observado os animais submetidos à IR intestinal (IR) apresentaram aumento significativo do número de leucócitos em relação ao determinado nas amostras obtidas dos animais do grupo Sham. O tratamento dos animais com estradiol 30 min após a isquemia (E30) ou 24 h antes da indução da isquemia (E24) foi efetivo em prevenir o aumento do número destes. Ainda, complementando esta análise celular foram investigamos os tipos celulares encontrados no fluido intestinal coletado. Os animais do grupo IR apresentaram aumento significativo do número de linfócitos, monócios e de granulócitos, quando comparado aos valores do grupo de animais falsamente operados (Sham). Nos animais tratados com estradiol foi observada significativa diminuição da contagem total do número de leucócitos. No grupo E30 o número de linfócitos também reduz significativamente, por outro lado, os animais do grupo E24 não tiveram alteração do perfil leucocitário. 
Tabela 2 - Número de leucócitos totais e diferencial (x $\left.10^{3} / \mathrm{mL}\right)$ encontrados no líquido intestinal recuperado da embalagem plástica dos ratos após a IR intestinal. Os grupos de estudo consistiram de animais tratados com estradiol 30 min após ou 24 h antes da indução da isquemia e também como controle animais falsamente submetidos a IR intestinal (Sham).

\begin{tabular}{ccccc}
\hline Leucócitos & Sham & IR & E30 & E24 \\
\hline Totais & $2710 \pm 0,27$ & $4689 \pm 0,57^{*}$ & $2729 \pm 0,3 \gamma$ & $3400 \pm 0,42 \gamma$ \\
Linfócitos & $1425 \pm 186,8$ & $2700 \pm 426,2^{*}$ & $1267 \pm 189,2 \gamma$ & $1775 \pm 265,8$ \\
Monócitos & $111,1 \pm 26,06$ & $250 \pm 52,17^{*}$ & $212,5 \pm 39,81$ & $233,3 \pm 47,14$ \\
Granulócitos & $737,5 \pm 103,4$ & $1633 \pm 194,4^{*}$ & $1213 \pm 183,7$ & $1511 \pm 272,1$ \\
\hline
\end{tabular}

Os dados representam a média \pm EPM de 8-10 experimentos. $* \mathrm{P}<0,05$ em relação ao grupo Sham; ${ }^{\gamma} \mathrm{P}<0,05$ em relação ao grupo IR intestinal. 


\subsection{Efeito da IR intestinal sobre o número de leucócitos e de plaquetas circulantes}

A tabela 3 representa o número total de leucócitos e plaquetas circulantes encontrados nas amostras de sangue coletadas no período inicial e final da IR intestinal. É possível verificar que com exceção dos grupos controles (Basal e Sham) o grupo submetido à IR intestinal apresentou aumento da contagem de leucócitos. Além disso os animais submetidos à IR intestinal (IR) apresentaram aumento significante do número total de leucócitos circulantes, em relação ao quantificado no grupo Sham ao final do período de IR intestinal. Observamos que a IR intestinal mobilizou aproximadamente 8 vezes mais leucócitos do que o grupo falsamente operado (IR $=59,4 \%$ / Sham $=7,26 \%$ ). Já em relação aos tratamentos dos animais com estradiol, apenas o tratamento 30 min após a indução da isquemia diminuiu de modo significante o número de leucócitos circulantes em relação aos animais não tratados. Complementando a análise por meio do índice de aumento do número de leucócitos, notamos o quanto a contagem de leucócitos aumentou entre o período inicial e final. Ainda o tratamento dos animais com estradiol 30 min após a indução da isquemia diminuiu o número de leucócitos circulantes ( $\mathrm{IR}=59,4 \%$ / E30 = 39,87\%). Por outro lado, animais do grupo tratado com estradiol $24 \mathrm{~h}$ antes da indução da isquemia (E24) não apresentaram significativa alteração em relação ao número de leucócitos circulantes quando comparado com os animais submetidos a IR intestinal e não tratados.

Dando sequência à análise dos leucócitos circulantes quantificamos os diferentes tipos celulares entre o período inicial e final dos experimentos. Além destes, o número de plaquetas nestes períodos também foi investigado. Como pode ser observado na tabela 3 , não houve mudança significativa do número de linfócitos. Por outro lado, os monócitos tiveram aumento do seu número nos animais após a IR intestinal, em relação ao início do experimento. Em relação aos granulócitos observou-se também maior número destas células no período final do experimento em todos os grupos, exceto no grupo Sham. Adicionalmente, houve aumento no número de granulócitos circulantes no grupo IR, em relação ao quantificado no sangue dos animais grupo Sham. Contudo o tratamento dos animais com estradiol em ambos os períodos (E30 e E24) não modificou o número de granulócitos em relação aos animais do grupo IR não tratados. Por fim, a IR intestinal não interferiu com o número de plaquetas circulantes, exceto no tratamento com estradiol 24 h, o qual aumentou o número de plaquetas. 
Tabela 3 - Contagem total de leucócitos, diferencial (linfócitos, monócitos e granulócitos) e plaquetas $\left(\mathrm{mm}^{3}\right)$ no sangue de ratos submetidos à isquemia (45 min) e reperfusão intestinal (2 horas - IR intestinal). Os grupos consistiram de animais tratados com estradiol 30 min após ou $24 \mathrm{~h}$ antes da indução da isquemia, animais falsamente submetidos a IR intestinal (Sham) e animais não manipulados (Basal).

\begin{tabular}{cccccc}
\hline Leucócitos & Basal & Sham & IR & E30 & E24 \\
\hline Totais & & & & & \\
Inicial & $10663 \pm 525,7$ & $11646 \pm 517,8$ & $10892 \pm 475,9$ & $10282 \pm 575,4$ & $9788 \pm 365,7$ \\
Final & - & $12492 \pm 904,3$ & $17362 \pm 1005^{*} \alpha$ & $14382 \pm 384,2^{*} \gamma$ & $16006 \pm 791,8^{*}$ \\
\% de & & & & & \\
aumento & - & 7,26 & 59,4 & 39,87 & 63,52 \\
Linfócitos & & & & & \\
Inicial & $7394 \pm 361,6$ & $8546 \pm 485,6$ & $7815 \pm 413,1$ & $7282 \pm 519,9$ & $7944 \pm 476$ \\
Final & - & $7277 \pm 75,2$ & $6585 \pm 407,9$ & $5767 \pm 437,2$ & $6689 \pm 427$ \\
Monócitos & & & & & \\
Inicial & $418,8 \pm 50,18$ & $446,2 \pm 43,29$ & $392,3 \pm 26,46$ & $318,2 \pm 22,64$ & $405,6 \pm 24,88$ \\
Final & - & $500 \pm 69,8$ & $661,5 \pm 116,3^{*}$ & $508,3 \pm 31,28$ & $527,8 \pm 50,36$ \\
Granulócitos & & & & & \\
Inicial & $2850 \pm 228,8$ & $2654 \pm 244,8$ & $2685 \pm 200,6$ & $2573 \pm 189,3$ & $2428 \pm 123,9$ \\
Final & - & $4715 \pm 730,2$ & $10115 \pm 994,1 * \alpha$ & $8858 \pm 1209 *$ & $9106 \pm 947,6 *$ \\
Plaquetas & & & & & \\
Inicial & $991,5 \pm 112,1$ & $758,9 \pm 33,14$ & $749,3 \pm 46,45$ & $791,5 \pm 37,05$ & $879,2 \pm 48,67$ \\
Final & - & $836,1 \pm 26,6$ & $759,4 \pm 48$ & $883,8 \pm 45,16$ & $1007 \pm 46,52 \gamma$ \\
\hline
\end{tabular}

Os dados representam a média \pm EPM de 17-26 experimentos. ${ }^{*} \mathrm{P}<0.05$ em relação ao valor inicial do experimento de cada grupo; ${ }^{\alpha} \mathrm{P}<0.05$ em relação ao valor final do grupo Sham; ${ }^{\gamma} \mathrm{P}<0.05$ em relação ao valor final do grupo IR intestinal. 
5.9 Efeito da IR intestinal e do tratamento dos animais com estradiol sobre o número de células da medula óssea

O gráfico 11 representa a contagem do número de células obtidas da medula óssea. Como pode ser observado a IR intestinal diminuiu de forma significativa o número de células recuperadas nas amostras de lavado medular em relação ao obtido nas amostras dos animais do grupo Sham e Basal. O tratamento dos animais com estradiol $24 \mathrm{~h}$ antes da indução da isquemia aumentou de forma significativa o número de células da medula óssea, em comparação ao do grupo de animais submetidos à IR intestinal e não aos tratados com estradiol. 
Gráfico 11 - Número total de células na medula óssea em grupos dos ratos após a indução da IR intestinal. Os grupos também consistiram de animais tratados com estradiol 30 min após ou $24 \mathrm{~h}$ antes da indução isquemia, animais falsamente submetidos a IR intestinal (Sham) e animais não manipulados (Basal). Os dados representam a média \pm EPM de 10-14 experimentos. ${ }^{\phi} \mathrm{P}<0,05$ em relação ao grupo Basal; * $\mathrm{P}<0,05$ em relação ao grupo Sham; ${ }^{\gamma} P<0.05$ em relação ao grupo IR intestinal.
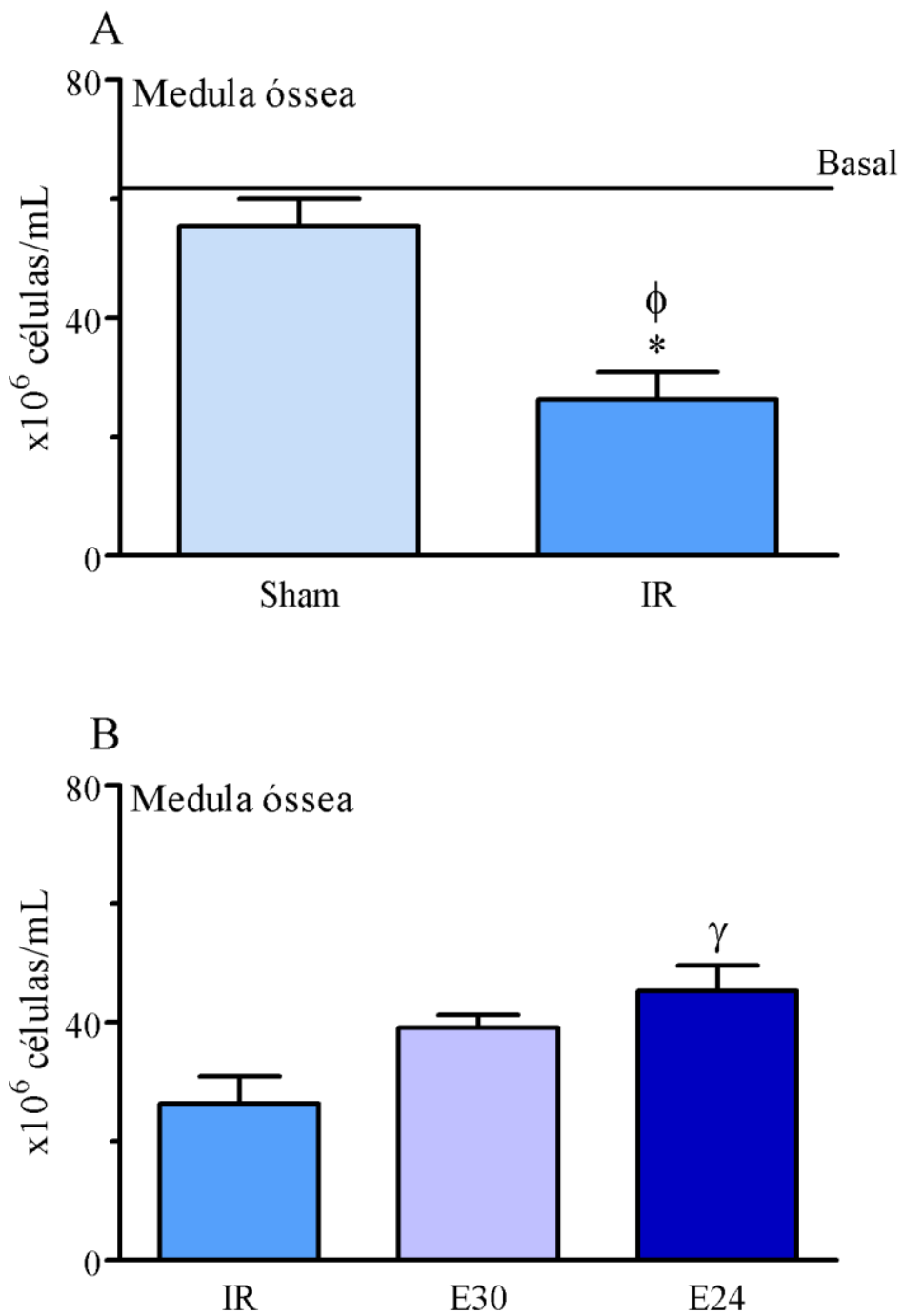


\subsection{Efeito da IR intestinal e do tratamento dos animais com estradiol sobre a migração in vitro de neutrófilos}

O gráfico 12 apresenta os dados de a migração de neutrófilos circulantes de animais submetidos à IR intestinal. Os dados obtidos indicaram que neutrófilos apresentaram maior migração quando obtidos após a IR intestinal, em comparação a de neutrófilos que migram dos animais do grupo Sham (Painel A). Com respeito ao efeito do tratamento dos animais com estradiol, nossos dados revelaram que ambos os protocolos de estudo (E30 e E24) apresentaram significativa redução do número de neutrófilos migrados de uma superfície para outra da placa de quimiotaxia. 
Gráfico 12 - Ensaio de migração de neutrófilos de ratos submetidos à IR intestinal. Os grupos também consistiram de animais tratados com estradiol 30 min após ou 24 h antes da indução da isquemia e de animais falsamente submetidos a IR intestinal (Sham). Os dados representam a média \pm EPM de 7-8 experimentos. $* \mathrm{P}<0,05$ em relação ao grupo Sham; ${ }^{\gamma} \mathrm{P}<0,05$ em relação ao grupo IR intestinal.
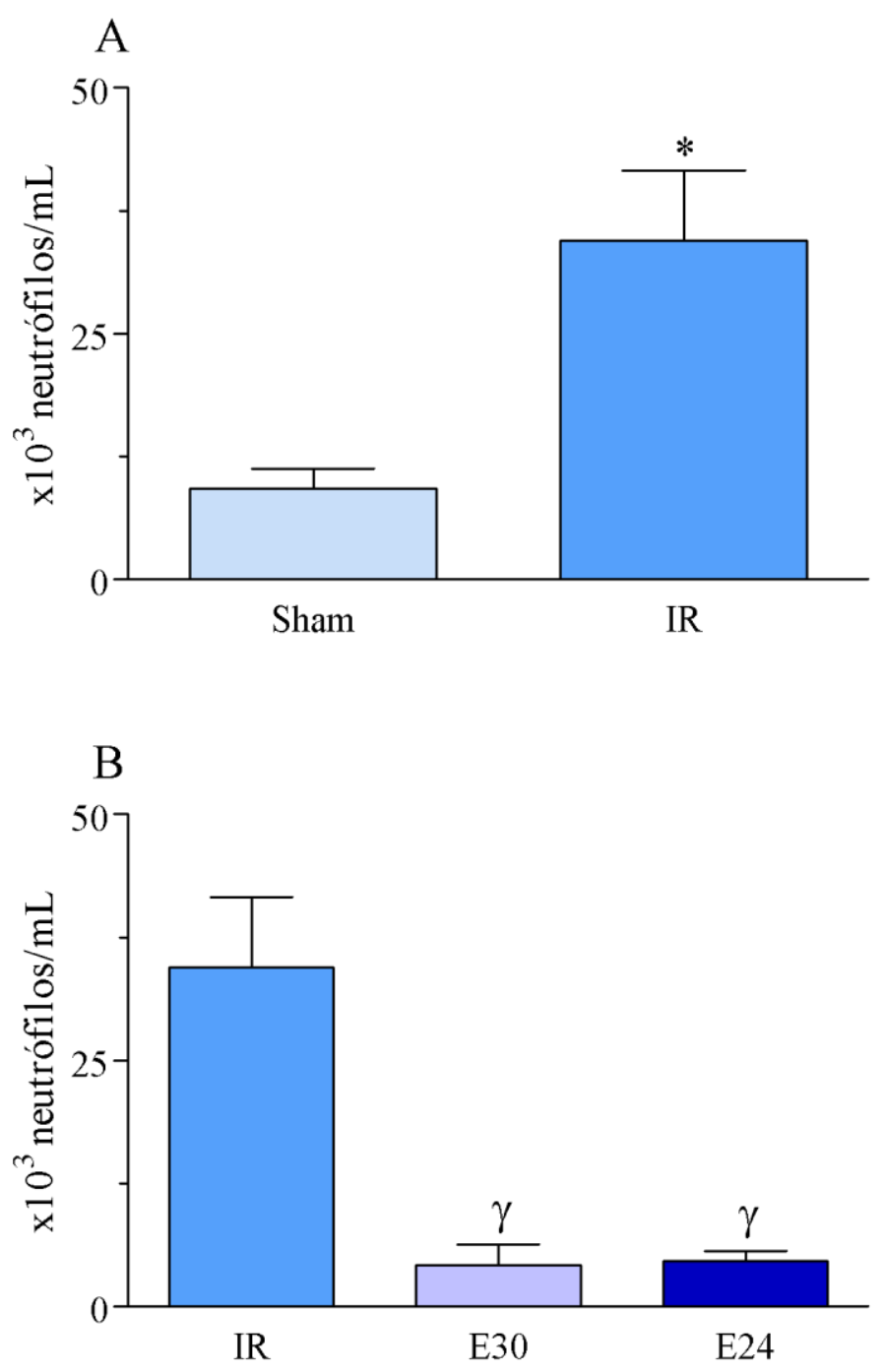


\subsection{Efeito da IR intestinal e do tratamento dos animais com estradiol sobre a concentração no soro de fosfatase alcalina e lactato desidrogenase}

Para analisar os efeitos associados a lesão tecidual da IR intestinal foram investigados dois marcadores a fosfatase alcalina e a lactato desidrogenase. O gráfico 13 indica que a concentração sérica de fosfatase alcalina aumentou de forma significativa após a indução da IR intestinal, em relação ao grupo Sham (Painel A). Por outro lado, o tratamento dos animais com estradiol 30 min antes da indução da IR intestinal preveniu o aumento da concentração de fosfatase alcalina causado pela IR intestinal. Em contraste, o tratamento dos animais com estradiol $24 \mathrm{~h}$ antes da indução da isquemia não foi eficaz em alterar a concentração de fosfatase alcalina, quando comparado ao observado nos animais do grupo IR intestinal não tratados com estradiol. 
Gráfico 13 - Atividade de fosfatase alcalina no soro de ratos submetidos à intestinal. Os grupos consistiram de animais tratados com estradiol 30 min após ou 24 h antes da indução da isquemia), animais falsamente submetidos a IR intestinal (Sham) e animais não manipulados (Basal). Os dados representam a média \pm EPM de 8-13 experimentos. $* \mathrm{P}<0,05$ em relação ao grupo Sham; ${ }^{\gamma} \mathrm{P}<0,05$ em relação ao grupo IR intestinal.
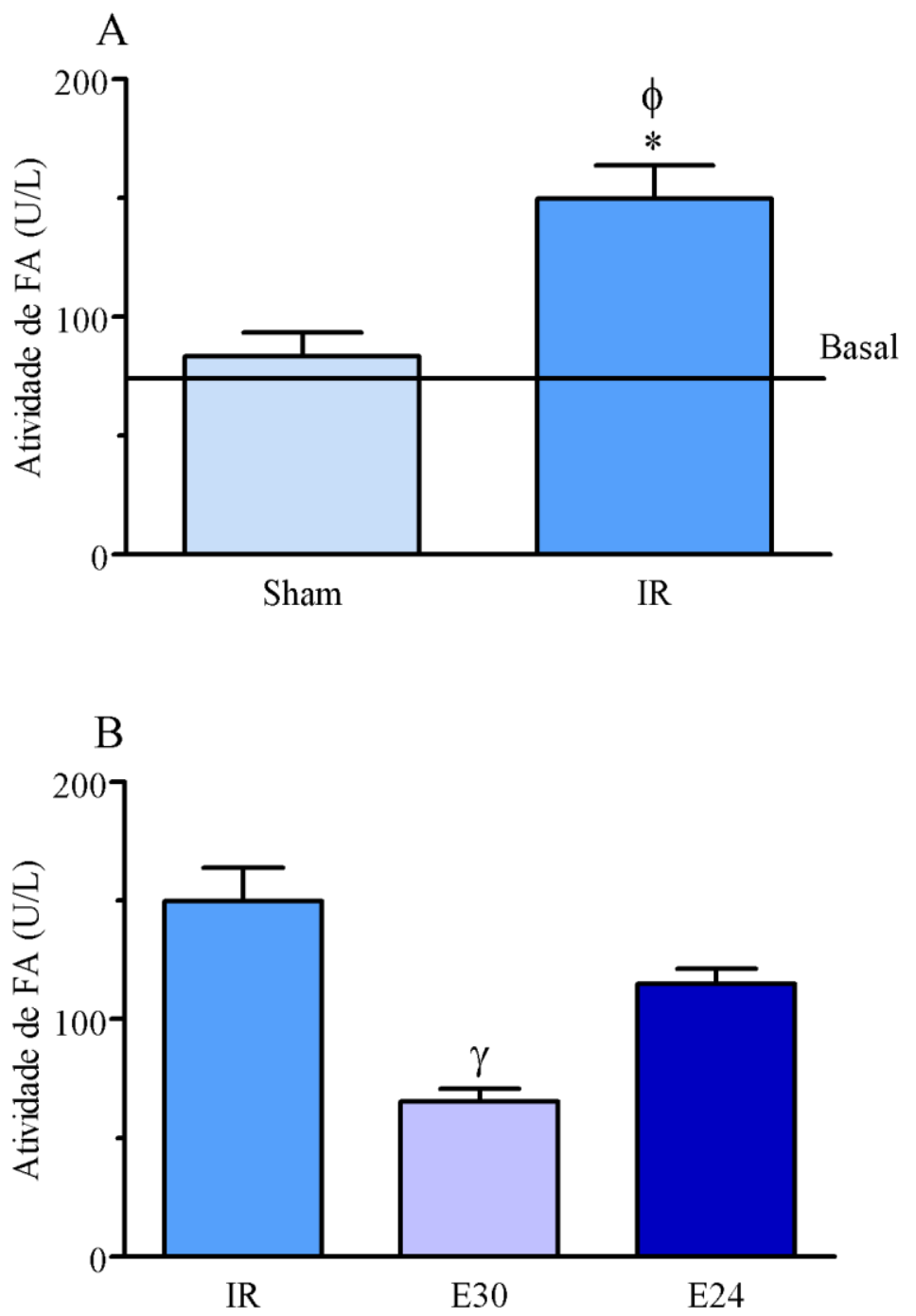
Em relação à lactato desidrogenase $(\mathrm{LDH})$ nossos dados indicaram que a IR intestinal causou aumento significativo desta enzima, quando comparado ao quantificado no soro dos animais do grupo falsamente operado e não manipulados (Gráfico 14, painel A). Ainda, o tratamento dos animais com estradiol 30 min após ou 24 h antes da indução da IR intestina teve efeito protetor sobre o aumento de atividade da LDH. 
Gráfico 14 - Concentração de lactato desidrogenase (LDH) no soro de ratos submetidos à IR intestinal. Os grupos também consistiram de animais tratados com estradiol 30 min após ou $24 \mathrm{~h}$ antes da indução da isquemia), animais falsamente submetidos a IR intestinal (Sham) e animais não manipulados (Basal). Os dados representam a média \pm EPM de 8-13 experimentos. ${ }^{*} \mathrm{P}<0,05$ em relação ao grupo Sham; ${ }^{\gamma} \mathrm{P}<0,05$ em relação ao grupo IR intestinal.
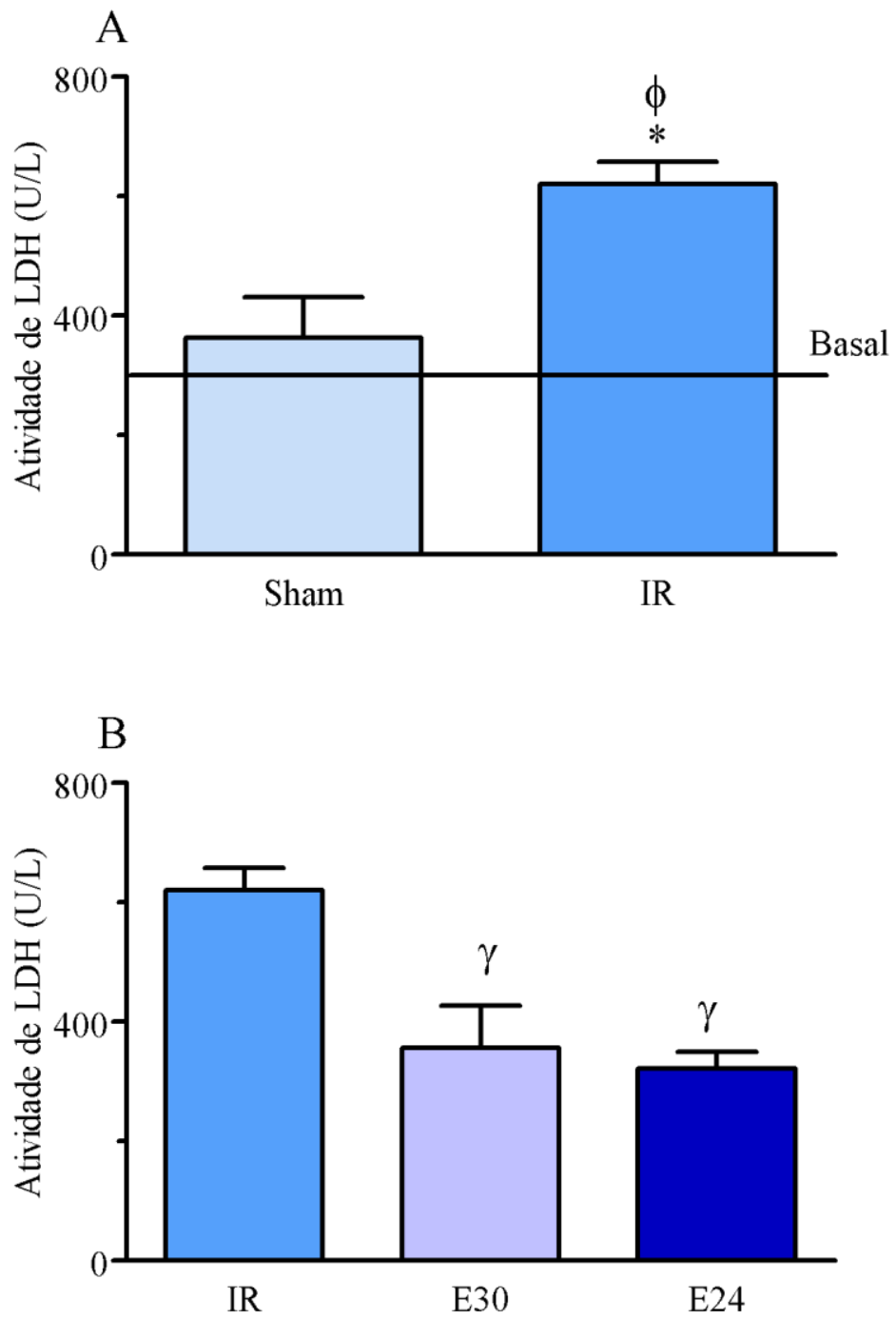


\subsection{Efeito da IR intestinal e do tratamento dos animais com estradiol sobre a concentração no soro de mediadores}

Os dados da Tabela 4 se referem a concentração obtida de mediadores no soro de animais submetidos à IR intestinal (IR). Como pode ser observado houve aumento significativo de todas as citocinas analisadas no grupo IR, em relação aos grupos controle (Basal e Sham). Por outro lado, o tratamento dos animas com estradiol (E30 eE24) reduziu a concentração de: IL-1 $\beta$, IL-10, VEGF, MIP-1 $\alpha$, MIP-2, MCP-1, GRO/KC e IP-10. Em contraste, o grupo de animais tratados com estradiol $24 \mathrm{~h}$ antes da indução da isquemia (E24) reduziu a concentração no soro de: IL-6, TNF- $\alpha$, GM-CSF, RANTES, enquanto os valores de: IL-12p70, IL-17 e INF- $\gamma$, não foram modificados por nenhum dos protocolos de tratamento com estradiol utilizado. 
Tabela 4 - Quantificação de mediadores ( $\mathrm{pg} / \mathrm{mL}$ ) no soro de ratos submetidos à IR intestinal. Os grupos também consistiram de animais tratados com estradiol 30 min após ou 24 h antes da indução da isquemia, animais falsamente submetidos a IR intestinal (Sham) e animais não manipulados (Basal).

\begin{tabular}{|c|c|c|c|c|c|}
\hline & Basal & Sham & IR & $\mathbf{E 3 0}$ & E24 \\
\hline IL-1及 & $47,65 \pm 10,94$ & $77,7 \pm 17,3$ & $230 \pm 40,12 \phi^{*}$ & $68,04 \pm 14,25 \gamma$ & $81,04 \pm 12,62 \gamma$ \\
\hline IL-10 & $119,8 \pm 23,42$ & $118,3 \pm 31,05$ & $733,7 \pm 138 \phi^{*}$ & $251 \pm 71,34 \gamma$ & $352,3 \pm 70 \gamma$ \\
\hline VEGF & $46,21 \pm 9$ & $63,37 \pm 12,45$ & $119,6 \pm 17,61 \phi^{*}$ & $59,2 \pm 5,4 \gamma$ & $68,96 \pm 7 \gamma$ \\
\hline 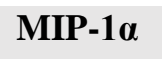 & $19,21 \pm 3$ & $16,55 \pm 1,3$ & $159,3 \pm 36,4 \phi^{*}$ & $56,22 \pm 8,35 \gamma$ & $52,25 \pm 11,92 \gamma$ \\
\hline MCP-1 & $793 \pm 136,1$ & $88,3 \pm 127,5$ & $3512 \pm 798 \phi^{*}$ & $1458 \pm 252 \gamma$ & $1514 \pm 193,5 \gamma$ \\
\hline GRO/KC & $8,92 \pm 0,06$ & $203,9 \pm 37,74$ & $1923 \pm 388,1 \phi^{*}$ & $362 \pm 58 \gamma$ & $855,6 \pm 138 \gamma$ \\
\hline IP-10 & $410 \pm 28,46$ & $370,1 \pm 19,43$ & $988,3 \pm 126 \phi^{*}$ & $594 \pm 65,11 \gamma$ & $598,1 \pm 60 \gamma$ \\
\hline TNF- $\alpha$ & $3,26 \pm 0,4$ & $4,32 \pm 0,74$ & $31,52 \pm 10,7 \phi^{*}$ & $12,2 \pm 1,86$ & $10,04 \pm 1,94 \gamma$ \\
\hline GM-CSF & $0,9 \pm 0,1$ & $0,89 \pm 0,09$ & $2,6 \pm 0,46 \phi^{*}$ & $1,68 \pm 0,26$ & $1,02 \pm 0,09 \gamma$ \\
\hline IL-6 & $0,1 \pm 0,05$ & $0,15 \pm 0,06$ & $1,44 \pm 0,5 \phi^{*}$ & $0,48 \pm 0,27$ & $0,2 \pm 0,06 \gamma$ \\
\hline IL-12p70 & $40,47 \pm 8,9$ & $46,23 \pm 16,22$ & $157,3 \pm 27,15 \phi^{*}$ & $148,5 \pm 91,16$ & $144,7 \pm 25,16$ \\
\hline IL-17 & $6,65 \pm 1,4$ & $8,46 \pm 1,57$ & $20 \pm 2,5 \phi^{*}$ & $18,24 \pm 3$ & $18,35 \pm 3,3$ \\
\hline IFN- $\gamma$ & $0,05 \pm 0,02$ & $0,17 \pm 0,08$ & $0,5 \pm 0,1 \phi^{*}$ & $0,32 \pm 0,12$ & $0,14 \pm 0,07$ \\
\hline
\end{tabular}

Os dados representam a média \pm EPM de $10-12$ experimentos. ${ }^{\phi} \mathrm{P}<0,05$ em relação ao grupo Basal; *P<0,05 em relação ao grupo Sham; ${ }^{\gamma} P<0.05$ em relação ao grupo IR intestinal. 


\section{DISCUSSÃO}

Neste estudo investigamos o efeito da IR intestinal experimental em ratos, notadamente no local da indução da isquemia. Alguns aspectos sistêmicos consequentes à IR intestinal também foram avaliados. Para tanto, a isquemia intestinal foi realizada obstruindo-se o fluxo da AMS por meio de sua oclusão por 45 min. A seguir, o fluxo da artéria foi reestabelecido e a reperfusão intestinal iniciada. Decorridas $2 \mathrm{~h}$ de reperfusão intestinal os animais foram submetidos à eutanásia e os experimentos conduzidos.

Nossos estudos tiveram como base investigar se o estradiol poderia apresentar efeito modulador das consequências inflamatórias locais e sistêmicas da IR intestinal. Nesse sentido os animais foram tratados com estradiol 30 min após a indução da isquemia (E30) ou $24 \mathrm{~h}$ antes da indução da isquemia intestinal (E24). Inicialmente avaliamos a eficiência do tratamento dos animais com estradiol em elevar a concentração deste esteroide no sangue. Nossos dados mostraram que os tratamentos dos ratos com estradiol elevaram de forma significativa a concentração circulante de estradiol quando em comparação com os reduzidos níveis encontrados no soro dos animais do grupo de animais submetidos a IR intestinal (IR) e não tratados com estradiol. De fato, o tratamento dos animais $30 \mathrm{~min}$ antes da indução da isquemia intestinal gerou níveis de estradiol bastante elevados em relação ao tratamento dos animais $24 \mathrm{~h}$ antes da indução da isquemia intestinal. Ainda, a concentração sérica no grupo de ratos tratados com estradiol $24 \mathrm{~h}$ antes da isquemia intestinal foi similar ao encontrado nos animais do grupo IR. Estes dados sugerem que a via de administração do estradiol e sua metabolização podem ter interferido com a sua taxa circulante no período em que realizamos a sua determinação. Sabe-se também que o estradiol sofre metabolização hepática e extrahepática (CHALLIS et al., 1970; DE HERTOGH et al., 1970).

Consideramos que poderíamos investigar um potencial efeito preventivo do estradiol, com um tratamento preventivo ( $24 \mathrm{~h}$ antes da indução da isquemia) ou terapêutico, realizando um tratamento agudo (30 min após a indução da isquemia). Um efeito terapêutico neste modelo poderia depender de efeitos rápidos, que se iniciam poucos minutos após a sua administração. De fato, a via rápida de ação do estradiol é capaz de rapidamente modificar as vias intracelulares de sinalização do estradiol, tal efeito é atribuído a GPER-1 resultando em 
mobilização intracelular de cálcio, produção de cAMP, ativação da via de MAPK e da PI3K, podendo estimular vias que, direta ou indiretamente, modulam a expressão gênica. É interessante lembrar que a ação do estradiol (genômica clássica, não clássica e rápida) participam dos efeitos protetores do estradiol (BJÖRNSTRÖM; SJÖBERG, 2005; FILARDO et al., 2000; FILARDO, 2011 MAGGIOLINI et al., 2004; THOMAS et al., 2005).

A literatura mostra o papel protetor do estradiol em modelos de IR intestinal, conferindo maior proteção as pulmão de fêmeas, em proestro, quanto à permeabilidade vascular e recrutamento de neutrófilos comparado aos machos (DEITCH et al., 2007). No pulmão de machos tratados com estradiol, ocorre redução do aumento de permeabilidade vascular, MPO e da expressão de moléculas de adesão, além da produção pulmonar de IL-10 e IL-1 $\beta$ (BREITHAUPT-FALOPPA et al., 2013). Ainda, no intestino de fêmeas ovariectomizadas diminui a lesão intestinal e a expressão de iNOS (XIAO et al., 2004). Também em modelos de trauma seguido de choque hemorrágico, normaliza a resposta imune de fêmeas ovariectomizadas (KNÖFERL et al., 2001), diminuiu a lesão intestinal e geração de citocinas em segmentos de íleo in vitro em condições de hipóxia (HOMMA et al, 2005). O estradiol também diminui a capacidade in vitro de macrófagos do baço e esplenócitos de liberarem TNF- $\alpha$, IL-6 e IFN- $\gamma$ (HILDEBRAND et al., 2006).

Uma das repercussões da IR intestinal é o aumento de permeabilidade vascular intestinal. Durante a isquemia o acúmulo de íons nas células endoteliais faz com que ocorra influxo de líquido para das células, o que resulta em perda de fluido no espaço intravascular e aumento da viscosidade do sangue. Isso faz com que seja mais difícil o restabelecimento da microcirculação durante o período de reperfusão e ocorra o aumento da adesão de leucócitos no endotélio de vênulas pós-capilares e subsequente ativação, levando ao comprometimento da integridade do endotélio vascular e, portanto, maior permeabilidade vascular (BYARD, 2012; MASSBERG; MESSMER et al., 1998; VOLLMAR; MENGER, 2011). Os dados obtidos neste estudo revelaram que a IR intestinal aumentou o extravasamento do corante $\mathrm{AE}$ no duodeno, quando comparado ao grupo falsamente operado (Sham) e aos animais não manipulados (Basal), caracterizando um aumento de permeabilidade vascular intestinal, como indicado na literatura.

Analisando os dados dos grupos de animais tratados com estradiol observamos que diferentemente do encontrado no pulmão de animais submetidos a IR intestinal, nos quais o tratamento com estradiol 30 min após a indução da isquemia intestinal reduz a permeabilidade 
microvascular (BREITHAUPT-FALOPPA et al., 2014), o tratamento de 30 min não foi capaz de reduzir o aumento do extravasamento do corante AE. Por outro lado, animais tratados com estradiol $24 \mathrm{~h}$ antes da indução da isquemia reduziram de forma significativa o extravasamento de corante. Estes dados sugerem que o tratamento preventivo foi eficaz no controle das alterações vasculares no local da isquemia.

Estudos conduzidos por Homma et al., (2005) mostraram que o intestino de fêmeas é mais resistente ao trauma seguido de choque hemorrágico. Segundo os autores uma das possibilidades para essa proteção é que o fluxo sanguíneo no intestino das fêmeas é melhor preservado, em relação ao dos machos. Ainda, em níveis similares de isquemia intestinal, fêmeas se mostraram mais resistentes e em comparação a machos, a resposta inflamatória induzida em fêmeas é de menor magnitude. De fato, Deitch et al., (2008), mostraram que fêmeas em proestro têm, intrinsecamente, o intestino mais resistente a lesões causadas pela IR intestinal em comparação a machos.

Podemos associar o efeito protetor do estradiol na permeabilidade vascular intestinal à menor produção de citocinas e menor expressão de moléculas de adesão como em modelo de trauma seguido de choque hemorrágico (HOMMA et al., 2005; YU et al., 2006a), diminuindo, portanto, a adesão de leucócitos ao endotélio e sua subsequente lesão. Além disso, estudos de Yu et al., (2006a) relacionaram a redução de quimiocinas, citocina indutora de quimiotaxia de neutrófilos-1 (CINC-1) e citocina indutora de quimiotaxia de neutrófilos-3 (CINC-3), e ICAM-1 como eventos mediados por ER- $\alpha$ e ER- $\beta$ no intestino, após trauma seguido de choque hemorrágico. Em conjunto, os dados da literatura e os dados obtidos em nosso estudo permitem supor que o estradiol tem efeito preventivo contra o aumento da permeabilidade vascular intestinal causada pela IR intestinal. Podemos sugerir também uma ação do estradiol por meio da via genômica, ou seja, por meio dos ER intracelular. Contudo não é possível afirmar qual mecanismo está envolvido na ação do estradiol pois não foram feitos estudos para esclarece-los.

Além da análise da permeabilidade vascular no duodeno também avaliamos se a permeabilidade da mucosa intestinal poderia ser afetada pela IR intestinal. Nossos dados indicaram que a IR intestinal aumentou a permeabilidade da mucosa intestinal. De fato, observamos aumento da concentração de dextran-FITIC circulante após sua administração no lúmen do duodeno. Estudos clínicos (WIJNEN et al., 2002) e experimentais (QIN et al., 2011) de IR indicaram aumento da permeabilidade da mucosa intestinal. O mesmo ocorreu em 
modelos de trauma seguido de choque hemorrágico (CHANG et al., 2005; HOMMA et al. 2005) ou em hipoperfusão esplâcnica (HOLLAND et al., 2005). Assim nossos estudos sugeriram que a IR intestinal causou quebra da integridade da barreira intestinal.

É interessante considerar que a presença de proteases pancreáticas no lúmen intestinal, podem ampliar a lesão intestinal causada pela IR intestinal (QIN et al., 2011). Admite-se que essas enzimas diminuem a camada de muco que protege as células epiteliais do intestino. Além disso, após a isquemia intestinal ocorre uma diminuição do número de células caliciformes, cujos efeitos na produção e manutenção da camada de muco é bem estabelecida (CHANG et al., 2005; TÓTH et al., 2012). Estudos mostraram que a atividade secretora das células caliciformes faz com que elas sejam sujeitas aos efeitos do estresse do retículo endoplasmático, ou seja, acúmulo de proteínas mal enoveladas no retículo endoplasmático com consequente apoptose (KASER; BLUMBERG, 2010). Estes eventos, portanto, poderiam justificar a diminuição de células secretoras. Apesar do mencionado, o mecanismo exato responsável pela perda das camadas de muco do intestinal ainda não está totalmente esclarecido (CHANG et al., 2005; QIN et al., 2011).

Além da camada de muco, estudos mostraram o descolamento dos enterócitos da membrana basal ou sua apoptose, após a IR intestinal. Visto que estão localizados na ponta das vilosidades, região mais susceptível a hipóxia, este evento pode contribuir para a destruição da barreira intestinal (CHANG et al., 2005; DEITCH et al., 2008; TÓTH et al., 2012). Também devemos considerar o papel das células de Paneth, presentes na base das criptas de Lieberkühn. Estas células são produtoras de mediadores pró-inflamatórios e fonte de produtos antimicrobianos, podendo controlar assim, a translocação bacteriana (GROOTJANS et al., 2011; LENAERTS et al., 2013). Ainda, sendo uma célula secretora, as células de Paneth são susceptíveis ao estresse do retículo endoplasmático (TÓTH et al., 2012).

Nossos estudos indicaram que a IR intestinal causou aumento da permeabilidade vascular e da mucosa intestinal. Concluímos, portanto, que a IR intestinal compromete, no local onde foi desencadeada, a função das células endoteliais e das células que constituem a barreira intestinal. Um aspecto interessante desses dados recai sobre a indução de translocação bacteriana, que neste estudo não foi avaliada. De fato Vitoretti (2014) mostrou que a IR intestinal causou translocação bacteriana, avaliada no linfonodo e 5 dias após o início da reperfusão intestinal. Assim, é possível que o mecanismo de translocação bacteriana possa ser 
iniciado $2 \mathrm{~h}$ de reperfusão, justificando o observado no aumento da permeabilidade da mucosa intestinal neste estudo.

Com relação aos efeitos dos tratamentos dos animais com estradiol, apenas o tratamento de 30 min após a indução da isquemia reduziu a permeabilidade da mucosa intestinal. Embora tenhamos observado uma tendência de diminuição da permeabilidade da mucosa intestinal quando o estradiol foi administrado $24 \mathrm{~h}$ antes da indução da isquemia. Estudos de Sheth et al., (2010) mostraram que a resistência observada no intestino de fêmeas após trauma seguido de choque hemorrágico, em comparação aos machos, se deve à preservação da camada de muco intestinal. Além disso, Caruso et al., (2003) demonstraram que esta resistência se relaciona à fase do ciclo estral dos animais, sendo maior a proteção durante o proestro, quando se observa um pico de estradiol. Ainda, tal proteção se deve à resposta inflamatória ser de menor intensidade em comparação a machos. De fato, há menor produção de citocinas pró-inflamatórias (IL-6, TNF- $\alpha$ e MIP-2) e maior produção IL-10 e NO em fêmeas, quando comparado aos machos (HOMMA et al., 2005). Ainda, estudos mostraram o efeito inibidor do estradiol na produção de citocinas por meio do NF-kB e moderado aumento de NO pela cNOS, com paralela inibição da iNOS reduzindo produção de NO (KUREBAYASHI et al., 1997; MENDELSOHN; KARAS, 1999). Ainda, Sharawy et al., (2013), sugereiram que o estradiol pode exercer efeitos protetores na microcirculação intestinal ao restabelecer a atividade da eNOS e reduzir a da iNOS.

Reforça-se assim, o potencial papel protetor do estradiol, que em nosso estudo foi demonstrado por um tratamento terapêutico (30 min após a indução da isquemia) e não pelo tratamento preventivo ( $24 \mathrm{~h}$ antes da indução da isquemia). É possível sugerido que os mecanismos envolvidos no efeito terapêutico estão relacionados aos altos níveis de estradiol e seus efeitos por meio da via rápida, envolvendo o GPER-1. De fato, os efeitos foram observados no duodeno poucas horas antes da sua administração. Vale lembrar que Braniste et al., (2009) e Looijer-van Langen et al., (2011) mostraram o papel do ER- $\beta$ na permeabilidade da mucosa intestinal, em especial na modulação das proteínas da zona de oclusão. Todavia, não podemos afirmar ser este o mecanismo envolvido na ação do estradiol, uma vez que não realizamos estudos para esclarece-los.

$\mathrm{Na}$ vigência de uma inflamação como a causada pela IR intestinal, neutrófilos são recrutados para o local da injúria e atravessam o endotélio das vênulas pós-capilares atingindo o sítio inflamatório (TAKAYAMA et al., 2001; TURNAGE et al., 1994). Neutrófilos são 
consideradas uma das primeiras células a chegar no local da inflamação durante a isquemia e afetam a microcirculação. Posteriormente, outros tipos celulares como monócitos e macrófagos chegariam, na fase de reperfusão do tecido, contribuindo para o aumento da lesão tecidual (YSEBAERT et al., 2000). Uma vez no tecido, os neutrófilos podem ser estimulados por citocinas geradas no local. Nessas condições os neutrófilos passam a liberar amplo espectro de mediadores inflamatórios e de enzimas contidas em seus grânulos (CARDEN; GRANGER, 2000; ELTZSCHIG; ECKLE, 2011; WELBORN et al., 1991). Com o objetivo de avaliar indiretamente a presença de neutrófilos no intestino, quantificamos a atividade de MPO no duodeno após a IR intestinal. Nossos dados indicaram aumento da atividade de MPO no duodeno dos animais após a IR intestinal, indicando que houve recrutamento ou ativação de neutrófilos em decorrência da IR intestinal.

O mecanismo de mobilização de leucócitos, em especial neutrófilos pela IR intestinal requer interação destas células com as células endoteliais, por meio do aumento da expressão de moléculas de adesão como a ICAM-1, molécula responsável pela mediação da adesão e migração transendotelial (GRANGER, 1997). Estudos conduzidos por Olanders et al., (2002) indicaram que a ICAM-1 é expressa em densidades variadas dependendo do órgão estudado e que a IR intestinal é responsável pelo aumento de expressão dessa molécula, principalmente em órgãos onde esta molécula é pouco expressa na sua forma constitutiva, como é o caso do intestino. Além disso outros autores (YU et al., 2006a) mostraram aumento da expressão de moléculas de adesão, no intestino, fígado e pulmão, em modelo de trauma seguido de choque hemorrágico ou em estudo clínico (SOUSA et al., 2015). Ainda, dados do nosso laboratório (BREITHAUPT-FALOPPA et al., 2014) demonstraram aumento da expressão de ICAM-1 no pulmão após a IR intestinal. O sistema complemento também pode ter relação, uma vez que em modelo de IR intestinal ele regula a expressão de ICAM-1 (BOROS et al., 1995; CERQUEIRA et al., 2005; KUBES et al., 1996). Embora não tenhamos investigado, é razoável supor que o recrutamento de neutrófilos para o duodeno neste modelo possa ser decorrente do aumento da expressão de ICAM-1. Estudos nesse sentido deverão ser conduzidos futuramente.

$\mathrm{Na}$ medida em que consideramos neste estudo que o estradiol pode exercer efeito modulador da inflamação causada pela IR intestinal, avaliamos se o tratamento dos animais com estrógeno poderia modificar o recrutamento de neutrófilos para o duodeno. Nossos dados indicam que nenhum dos protocolos de tratamento com estradiol modificou a atividade de MPO do duodeno após a IR intestinal. Visto que observamos a participação do estradiol no 
controle da permeabilidade vascular e da mucosa intestinal, mas não no controle do recrutamento de neutrófilos, estes dados reforçam dados anteriores acerca da dissociação dos mecanismos reguladores da permeabilidade vascular e recrutamento celular no pulmão após a IR intestinal (CAVRIANI et al., 2004).

É de interesse mencionar que o tratamento dos animais com estradiol revelou um efeito protetor diferente dependendo do órgão após a IR intestinal. De fato, nossos dados não indicaram efeito protetor do estradiol no duodeno em animais tratados $30 \mathrm{~min}$ após o estabelecimento da isquemia intestinal. Todavia, Breithaupt-Faloppa et al., (2014) demonstraram que esse tratamento efetivamente protegeu o pulmão da inflamação após IR intestinal, como evidenciado pela diminuição da atividade de MPO no pulmão. Dessa forma podemos sugerir que uma dose de estradiol distinta ou sua administração em tempos diferentes dos utilizados poderia demonstrar efeito protetor na atividade da enzima MPO no duodeno, como demonstrado por exemplo por Yu et al., (2006a) em modelo experimental de trauma seguido de choque hemorrágico.

Com respeito às diferenças observadas entre o efeito protetor do estradiol no pulmão, mas não no intestino, eventualmente se relaciona com a densidade entre receptores $\alpha$ e $\beta$ de estradiol. Podemos considerar que dependendo da distribuição dos ER em diferentes órgãos, predominância de ER- $\beta$ no pulmão, ER- $\alpha$ no fígado e expressão igual de ER- $\alpha$ e ER- $\beta$ no intestino, ocorra um efeito modulador do estradiol diretamente relacionado, portanto à sua expressão nos tecidos (YU et al., 2006a). Além da participação da via genômica, foi relatada a participação da via não genômica no aumento de MPO intestinal. Estudos de Yu et al., (2007b) mostraram o efeito protetor do estradiol por meio da maior expressão da via fosfatidilinusitol 3-quinase/ serina treonina quinase (PI3K/Akt)

Dando sequência aos efeitos da IR intestinal sobre o intestino, em outra série de estudos nos propusemos a investigar se a IR intestinal poderia interferir com a motilidade intestinal. Estes estudos foram motivados pelos resultados de investigação realizada em colaboração com a Dra. Patricia Castelucci, do Departamento de Anatomia do ICB/USP, que mostraram alterações nos neurônios intestinais após a IR intestinal, em específico sobre a expressão do receptor P2X7 e em diferentes classes de neurônios no plexo mioentérico que tem sua densidade e tamanho reduzidos. Essas modificações da expressão do receptor P2X7 podem resultar em alterações da motilidade intestinal (MAROSTI et al., 2015; PALOMBIT et al., 2013; PAULINO et al., 2011). Em nosso modelo o estudo do trânsito intestinal foi utilizado 
como indicador da capacidade do intestino impulsionar seu conteúdo na direção aboral, representando indiretamente a motilidade intestinal. Para tanto, avaliamos o trânsito de partículas de carvão ativado. A metodologia utilizada é baseada no cálculo da distância percorrida, no intestino, de uma determinada quantidade de carvão ativado após sua administração por gavagem (RUWART et al., 1980).

Nosso dados indicaram que a IR intestinal causou significativa redução do trânsito intestinal, dados estes que estão em linha com os obtidos por Grossie et al., (2001), onde foram utilizados períodos de reperfusão de 24 e 48 h. Uma possível explicação para a perda de motilidade decorrente da IR intestinal pode ser o papel exercido pelo NO na regulação da contração do músculo liso intestinal por meio da ativação de neurônios não adrenérgicos e não colinérgicos (NANC) (ALEMAYEHU et al., 1994; VENKOVA; KRIER, 1994). Vale ressaltar o estudo de Takahashi et al., (2001) com S-metilisotioureia (SMT), um inibidor específico da isoforma iNOS. Esses autores mostraram que a iNOS deve estar envolvida no aumento de $\mathrm{NO}$ em modelo in vivo de IR intestinal, levando a alterações na motilidade intestinal em relação a duração da contração e número de contrações a cada 15 min em segmentos intestinais diretamente afetados e indiretamente afetados pela isquemia.

É interessante notar que estudos de Hebra et al., (1994) relacionam alteração da motilidade intestinal com a maior translocação bacteriana. Também se relacionam com nossos dados que mostram aumento da permeabilidade da mucosa intestinal, sugerem que em nosso estudo pode ocorrer translocação bacteriana. Além disso, outros mediadores inflamatórios gerados na isquemia intestinal também podem alterar a motilidade, como PAF, IL- $1 \beta$, TNF- $\alpha$, e assim causar mudanças no padrão funcional neuromotor (KINOSHITA et al., 2006; TAKAHASHI et al., 2001; VILLANUEVA; GIULIVI, 2010). Outro aspecto é o dano à própria musculatura do intestino, que também pode ser danificada pela IR intestinal, em especial pela mobilização de neutrófilos (PONTELL et al., 2011).

Um dado que nos chamou atenção foi a redução do trânsito intestinal no grupo Sham em relação aos animais não manipulados. Talvez estes dados indiquem que a laparatômia (falsa operação) seja capaz de modificar a motilidade intestinal. De fato, estudos experimentais mostraram que a laparatomia diminui a motilidade intestinal (BAUR; BOECKXSTAENS, 2004; CALCINA et al., 2005; SAGRADA et al., 1987). É interessante que estudos clínicos mostram diminuição da motilidade intestinal como uma resposta normal e inevitável de laparatomias (DELANEY, 2004; HOLTE;KEHLET, 2000). Estudos 
experimentais de Anup et al., (1999) e Thomas et al., (2001) mostraram que a laparatomia e um trauma suave (manuseio) do intestino leva a ativação de enterócitos e produção de espécies reativas de oxigênio, resultando em dano considerável da estrutura e função da mucosa intestinal. Ainda, Fukuda et al., (2005) mostraram, que a manipulação do intestino de ratos faz com que a motilidade gástrica caia em $40 \%$ e estudos clínicos de Todo et al., (1995) mostraram que em casos de IR intestinal relacionadas a transplantes frequentemente ocorre prejuízo da motilidade intestinal.

É interessante que Calcina et al., (2005) mostraram que animais falsamente operados para a IR intestinal apresentaram aumento significante de peptídeo vasoativo intestinal (VIP) acompanhando a diminuição do trânsito gastrointestinal. Contudo o aumento foi modesto em comparação ao observado após a IR intestinal. O VIP é secretado juntamente com NO de neurônios motores inibitórios, e tem papel inibitório no sistema nervoso entérico (COSTA et al., 1996; OLSSON; HOLMGREN, 2001). No conjunto podemos inferir que após a IR intestinal ocorre o aumento tanto de VIP como de NO e ambos podem exercer função inibitória da atividade contrátil do intestino (HASSOUN et al., 2001; OLSSON; HOLMGREN, 2001; SALZMAN, 1995). Portanto, a despeito da cirurgia haver contribuído para a redução da motilidade intestinal, nossos dados sugerem que existe uma perda ainda mais acentuada da motilidade após a IR intestinal.

No contexto dos efeitos do tratamento dos animais com estradiol nossos resultados sugerem que o esteroide melhora a motilidade intestinal, ao promover o aumento significativo do trânsito intestinal nos animais. Vale lembrar que o tratamento com estradiol 24 h antes da isquemia, elevou a motilidade intestinal a valores similares aos observados nos animais do grupo Sham e Basal. Por outro lado, apenas uma tendência de melhora foi detectada nos animais tratados com estradiol 30 min após a indução da isquemia. Deste modo, entendemos que o estradiol, quando administrado previamente à IR intestinal é capaz de induzir efeito modulador da motilidade no intestino. Nossos dados permitem inferir que o estradiol poderia exercer efeito preventivo em condições inflamatórias do intestino e mais precisamente naquelas envolvendo a IR intestinal como utilizada neste estudo. Por outro lado, é interessante lembrar que estudos dos efeitos do estradiol sobre a contratilidade intestinal mostraram que o intestino dos animais tratados com estradiol ou incubados com estradiol apresentaram redução na contratilidade (PINES et al., 1998; SHIMOMURA et al., 2009). Nossa percepção para esta aparente discrepância recai sobre os efeitos do estradiol quando administrado em animais que 
serão submetidos ao estresse da IR intestinal em comparação com a repercussão do tratamento com estradiol em animais que não foram alvo do estresse inflamatório.

Com base nesses dados podemos supor que o tratamento com estradiol, em específico o que reproduz os valores fisiológicos de ratas (estradiol 24 h), conferiu uma proteção contra a inflamação causada pela IR intestinal assim como mostrado no estudo de Homma et al., (2005). Estes autores mostraram que o intestino de fêmeas é mais resistente à lesão e inflamação do que o de machos, em modelo de trauma seguido de choque hemorrágico. Diversos estudos sustentam o conceito do envolvimento do NO como mediador da IR intestinal. Ainda, o papel do estradiol sobre a geração de NO também é discutido (FUKUMOTO et al., 2013; XIAO et al., 2004). No contexto da IR intestinal a participação do NO no controle da inflamação pulmonar e intestinal já foi estabelecida (CAVRIANI et al., 2004; TAKAHASHI et al., 2001; SUZUKI et al., 2000). Ainda estudos de nosso grupo correlacionam a interação do NO com o estradiol na inflamação pulmonar após a IR intestinal em ambos os gêneros (BREITHAUPT-FALOPPA et al., 2013, 2014).

Uma possível explicação para nossos dados pode ser baseada nos estudos que mostraram que o NO produzido pela eNOS, diferente do gerado pela iNOS, protege o intestino da inflamação e das lesões decorrentes de hipóxia (CAPLAN et al., 1994). Dessa forma podemos hipotetizar que o papel protetor do estradiol na motilidade é devido a produção de NO por eNOS, como em estudo de Sharawy et al., (2013) ou mesmo pela inibição da produção excessiva de NO pela iNOS, que estudos já mostraram estar relacionada à perda de motilidade intestinal (TAKAHASHI et al., 2001).

Sabe-se que a inervação colinérgica do sistema gastrointestinal é exuberante (FURNESS; COSTA, 1980). Paralelamente existem estudos indicando o papel do nervo vago no controle anti-inflamatório de doenças inflamatórias intestinais. Borovikova et al., (2000) mostraram em modelo experimental de sepse que o estímulo do nervo vago reduz a produção de citocinas, como TNF por macrófagos do baço. Estes dados levam ao entendimento de que existe uma conexão entre o sistema nervoso e imune, a chamada via colinérgica antiinflamatória (TRACEY, 2002). Entende-se que os mediadores inflamatórios ativam nervos sensoriais e estes informam ao sistema nervoso central a inflamação, este por sua vez libera mediadores que modulam a inflamação local e as células inflamatórias (TRACEY, 2009). Portanto, a ativação de neurônios entéricos que liberam acetilcolina e talvez outros 
neurotransmissores poderia resultar no controle da inflamação intestinal e restabelecer a homeostasa (MANTEOLI; BOECKXSTAENS, 2013).

De maneira a investigar a participação do estímulo colinérgico na IR intestinal realizamos a análise da contração isométrica ex vivo do íleo isolado. Neste caso não foram utilizados segmentos de duodeno, mesmo sendo este a porção do intestino utilizada em outras análises, uma vez que estudos prévios (não apresentados) revelaram que os segmentos de íleo apresentavam uma curva dose-resposta mais representativa. Construímos curva dose-resposta à metacolina em íleo isolado de animais submetidos à IR intestinal e seus respectivos controles. Investigamos também o efeito do tratamento dos animais com estradiol. Os dados obtidos indicaram que a IR intestinal induziu hiporreatividade à metacolina no íleo isolado. De fato, estudos anteriores do nosso laboratório mostraram que a IR intestinal causa hiporreatividade brônquica à metacolina. Naquele caso mostramos que a IL1 $\beta$, gerada no intestino após a IR intestinal, medeia a geração de NO no pulmão e este se relaciona com a menor resposta contrátil à metacolina (COELHO et al., 2007). Se mecanismos similares estão operando também no íleo isolado nossos dados não permitem afirmar.

Outros estudos confirmam a hiporreatividade intestinal após a IR intestinal. Ballabeni et al., (2002) em modelo experimental de IR mesentérica leve relatou redução da resposta contrátil à acetilcolina após $24 \mathrm{~h}$ de reperfusão, a qual pode ser revertida com a redução de NO pela iNOS e neuropeptíde, como o VIP. Ainda, Ozacmak et al., (2007) mostraram também a redução da contratilidade de segmentos íleo ao carbacol após IR intestinal. Adicionalmente, os autores revelaram que a redução do estresse oxidativo e do recrutamento de neutrófilos tem papel protetor da resposta contrátil do íleo. Portanto, os nossos dados referentes ao recrutamento/atividade de neutrófilos podem justificar a hiporreatividade dos segmentos de íleo no modelo estudado. Ainda, não só os mediadores inflamatórios gerados na isquemia intestinal podem modificar a reatividade intestinal (KINOSHITA et al., 2006; TAKAHASHI et al., 2001; VILLANUEVA; GIULIVI, 2010). Mas também a lesão da musculatura intestinal após a indução da IR intestinal (Pontell et al., 2011).

Nossos dados indicam que o tratamento com estradiol mostrou uma tendência de aumento da resposta contrátil. É possível que a perda de significância estatística decorra da alta taxa de variabilidade dos dados. Além disso, dados não publicados do nosso laboratório sugerem que fêmeas ovariectomizadas e submetidas à IR intestinal tem maior comprometimento da resposta contrátil de segmentos de íleo à metacolina, em comparação a 
fêmeas não ovarectomizadas e submetidas à IR intestinal. Havendo, portanto, indicação de que o estradiol pode ter papel ter protetor da contratilidade intestinal à metacolina.

É interessante considerar o eixo intestino-encéfalo nas alterações intestinais causadas pela IR intestinal. De fato, existem estudos indicando que em modelo de IR renal (BERNIK et al., 2002) e choque hemorrágico (GUARINI et al., 2003) há melhora após a ativação do sistema nervoso colinérgico. Ainda no contexto da interação intestino-encéfalo, os estudos realizados por Zhou et al., (2012) indicaram que em modelo experimental de IR intestinal, a inflamação intestinal pode levar a lesão cerebral e disfunção da memória, em parte por meio da ativação da micróglia, aumentando assim a lesão por espécies reativas de oxigênio, a resposta inflamatória e apoptose celular.

Por fim vale salientar que ainda não dispomos de resultados que permitam avaliar a correlação entre o transito intestinal in vivo e a menor resposta contrátil in vitro. Alguns aspectos merecem reflexão, pois é importante lembrar a existência de mecanismos endógenos de controle da motilidade intestinal que não atuam em situações isoladas como o sistema in vitro. Ainda, a dimensão dos segmentos de intestino envolvidos com a motilidade in vivo difere do investigado in vitro.

Os dados discutidos até o momento referem-se aos efeitos da IR intestinal sobre o intestino. Uma questão levantada pelos estudos de Narita et al., (2004) referiu-se às alterações inflamatórias do intestino após a IR intestinal, notadamente aquelas envolvendo a geração de citocinas, as quais sendo absorvidas pela cavidade peritoneal, poderiam ser disseminadas e assim desencadear efeitos sistêmicos em órgãos distantes do local onde a IR foi desencadeada. Narita et al., (2004) propuseram que a prevenção da absorção de produtos gerados no intestino poderia resultar na redução dos efeitos da IR intestinal. Para tanto, esses autores isolaram o intestino de animais submetidos à IR intestinal em "intestinal bags" para isolar o peritônio parietal, ou seja, isolar o intestino da cavidade abdominal. Obtendo assim uma análise mais pontual do intestino.

Nesse contexto, a próxima etapa do estudo foi investigar com mais detalhes o intestino sob IR intestinal. A razão dessa investigação, portanto, foi caracterizar o intestino como o "motor" da inflamação na IR intestinal. Como proposto por Deitch et al., (2001). Ainda considerando os dados obtidos por Breithaupt-Faloppa et al., (2014) sobre o papel do estradiol 
no pulmão, avaliamos se o estradiol poderia interferir também na atividade inflamatória no intestino.

O fluido peritoneal, ultrafiltrado do plasma que separa as duas camadas de peritônio na cavidade abdominal, também é denominado de fluido ascítico. Este termo se refere a qualquer fluido coletado dentro da cavidade abdominal. Existem diversas causas para o acúmulo de líquido peritoneal, sendo divididas em duas grandes causas: exsudativas ou transudativas. A primeira causa se refere, em geral, ao acúmulo de líquido peritoneal pelo excesso de fluxo do compartimento vascular para a cavidade peritoneal proveniente de um processo inflamatório ou neoplásico. Já a segunda causa seria a transudação de leitos capilares e da circulação linfática esplâncnica ou hepática, resultante do aumento da pressão venosa (MCDERMOTT et al., 1964; TARN; LAPWORTH, 2010). Podemos entender que o fluido peritoneal no presente estudo pode ser modulado por um fenômeno de exsudação.

Analisando primeiramente o volume de fluido intestinal recuperado nossos dados revelaram redução significativa do volume de fluido nos animais submetidos a IR intestinal, em comparação aos animais do grupo Sham. Embora ainda não tenhamos investigado os mecanismos reguladores de tal redução, sugerimos que a IR intestinal associada ao isolamento do intestino tenham alterado a pressão osmótica do plasma ou a pressão da veia porta. Esta sugestão decorre do fato de ambas (pressão osmótica e da veia porta) controlarem a formação de líquido na troca de fluido entre o sangue e os tecidos (SHERLOCK et al., 1981). Por outro lado, o maior volume de líquido intestinal coletado em animais do grupo Sham, poderia ser resultado da manipulação do animal. De fato, existem estudos indicando que a palpação exploratória do intestino eleva sua permeabilidade vascular (THOMAS et al., 2005). Além disso, se o volume do líquido coletado é alterado pela IR intestinal, então é razoável supor que animais do grupo Sham tenham gerado volume maior de fluido intestinal a ser recuperado pela embalagem plástica que acondicionamos o intestino. Vale lembrar que o tratamento dos animais com estradiol não interferiu com o volume do exsudato coletado, sugerindo que a alteração causada pela IR intestinal sobre a geração de fluidos no intestino não é mediada pelo estradiol.

Continuando os estudos sobre o fluido intestinal coletado, analisamos o conteúdo do corante AE. Consideramos assim avaliar o aumento da permeabilidade vascular no intestino. Observamos que apesar de não haver diferença significativa entre os grupos estudados, os dados sugeriram que o estradiol reduziu a concentração do corante AE extravasado em 
animais tratados com estradiol $24 \mathrm{~h}$ antes da indução da isquemia e uma tendência de diminuição no tratamento 30 min após a indução isquemia, assim como observado no estudo da permeabilidade vascular intestinal, que indicou um maior influxo de fluido dos vasos para o intestino. Devemos considerar que não observamos aumento do extravasamento de corante AE para o líquido intestinal, como seria esperado, uma vez que foi observado aumento do extravasamento de corante no próprio intestino, porque este fluido foi direcionado prioritariamente para o intestino. Assim, em conjunto os dados relativos ao volume de fluido intestinal e extravasamento de corante AE para o liquido intestinal e para o intestino, permitem supor que no evento da IR intestinal acontece um aumento da permeabilidade vascular intestinal e como resultado disso ocorre um influxo de fluido dos vasos sanguíneos para o intestino e em menor proporção para a cavidade abdominal.

Os estudos conduzidos por Narita et al., (2004) mostraram que o fluido intestinal contém maior concentração de IL-1 $\beta$, TNF- $\alpha$ e IL-8, quando comparada aos níveis plasmáticos dessas mesmas citocinas após a IR intestinal, ou seja, ocorre uma contenção destas citocinas na embalagem plástica, que de outro modo estariam na cavidade peritoneal. Entende-se, portanto, que o isolamento do intestino deve concentrar as citocinas na embalagem plástica, modificando assim a redistribuição sistêmica de citocinas.

Nossos estudos mostraram que a IL-10 também está presente no líquido intestinal. Podemos supor então que a IR intestinal induz mecanismos moduladores da inflamação local que podem contribuir para o controle da inflamação sistêmica e em órgãos distantes. A IL-10 é descrita como uma potente citocina anti-inflamatória que inibe a síntese das principais citocinas pró-inflamatórias, IL-6 (YILMA et al., 2012), IL-8 (YILMA et al., 2012), IL-12 (YANG et al., 1999), IFN- $\gamma$ (OLSZYNA et al., 1994; YANG et al., 1999) e TNF- $\alpha$ (OLSZYNA et al., 1994; YANG et al., 1999; YILMA et al., 2012), além de algumas quimiocinas (OLSZYNA et al., 2000). A IL-10 também participa da regulação da resposta imune humoral e atenua o recrutamento de neutrófilos em modelo de IR intestinal (MOSSER; ZHANG et al., 2008; SOUZA et al., 2003). Ainda, dados de nosso grupo mostraram que em modelo de IR intestinal o TNF- $\alpha$ dosado no soro dos animais mostrou relação direta com a concentração e IL-10, ou seja, quando o TNF- $\alpha$ foi inibido a quantificação de IL-10 também foi reduzida. Da mesma forma a inibição das enzimas NOS fez com que a concentração de IL10 e de IL-1 $\beta$ se elevassem (CAVRIANI et al., 2007). Dessa forma podemos sugerir que o 
aumento de IL-10 no fluido intestinal seja decorrente do acionamento de mecanismos endógenos de controle da inflamação causada pela IR intestinal.

A participação do estradiol no controle da geração de IL-10 não pode ser confirmada neste modelo. Realmente, o tratamento dos animais 30 min após a indução da isquemia não alterou de forma significante a concentração de IL-10 no líquido intestinal coletado após a IR intestinal. Entretanto, o tratamento dos animais com estradiol $24 \mathrm{~h}$ antes da indução da isquemia intestinal mostrou aparente tendência de normalizar a concentração de IL-10 aos valores obtidos nos animais do grupo Sham. É interessante considerar que a premissa deste estudo é avaliar o efeito terapêutico ou preventivo do estradiol sobre as consequências inflamatórias da IR intestinal. Nesse sentido consideramos positivo que o estradiol não tenha alterado a geração de IL-10. Ainda, seria de interesse adicional se o estradiol houvesse exacerbado a geração dessa citocina anti-inflamatória.

Em adição à IL-10, quantificamos a concentração de TNF- $\alpha$ no líquido intestinal. Nossos dados indicaram, assim como os dados de Narita et al., (2004), aumento de TNF- $\alpha$ em relação aos animais falsamente operados. Importante notar que a concentração desta citocina é menor que a determinada para a IL-10 e isto poderia fortalecer a ideia de que o aumento de IL-10 se relaciona ao controle de citocinas pró-inflamatórias por exemplo TNF- $\alpha$. Podemos sugerir, portanto, que o intestino sob o estresse da IR intestinal aciona o controle da inflamação local.

Vale lembrar que o tratamento dos animais com estradiol reduziu a concentração de TNF- $\alpha$ no líquido intestinal. Estes dados confirmam estudos que mostraram a ação protetora deste hormônio em modelos de IR intestinal (MA et al., 2001) e de trauma seguido de choque hemorrágico (CHEN et al., 2008; SUZUKI et al., 2007b). É de interesse mencionar que ambos os protocolos com estradiol foram eficazes em diminuir a concentração desta citocina. Assim, no caso do controle da geração de TNF- $\alpha$, o estradiol apresentou efeito preventivo e terapêutico. Considerando o papel do TNF- $\alpha$ na inflamação sistêmica os dados obtidos em animais após o tratamento com estradiol revestem-se de importância adicional.

A IR intestinal determina a inflamação local, sistêmica e em órgãos distantes do local onde foi desencadeada. Considerando os eventos celulares da inflamação originada pela IR intestinal os neutrófilos ocupam lugar de destaque (GRISHAM et al., 1990; TAKAYAMA et al., 2001; TURNAGE et al., 1994; WU et al., 2013) embora linfócitos (QIU et al., 2014; 
YANG et al., 2014) e macrófagos (BOROS et al., 1995; CERQUEIRA et al., 2005; JIANG et al., 2011) também são descritos como participantes da IR intestinal. Por esse motivo, neste estudo avaliamos o número de leucócitos presentes no fluido intestinal recuperado da embalagem plástica que isolou o intestino. Observamos que o mesmo se mostrou rico em leucócitos nos animais do grupo IR intestinal e que ambos os tratamentos com estradiol diminuíram de forma significativa o número de leucócitos.

Embora não tenhamos investigado os mecanismos desencadeados pelo estradiol que possam justificar a redução do número de leucócitos neste estudo, é possível sugerir que o estradiol poderia estimular a geração de NO (BREITHAUPT-FALLOPA et al., 2014) de maneira a reduzir a interação leucócito-endotélio. Como consequência o recrutamento leucocitário tenderia a ser menor nesses animais. Paralelamente um dos mecanismos possíveis seria pela da via rápida do estradiol, por meio da PI3K. De fato, estudos anteriores indicaram regulação da adesão de células por esta via em modelo de trauma seguido de choque hemorrágico (YU et al., 2007a, 2007b) e em estudos in vitro de neutrófilos humanos (CADWALLADER et al., 2002) e de camundongos (PURI et al., 2004).

Nossos dados indicaram aumento significativo, notadamente de linfócitos, e granulócitos, ainda em menor proporção aumento de monócitos, no líquido intestinal dos animais submetidos a IR intestinal. Com relação ao efeito do tratamento dos animais com estradiol observamos que somente o tratamento 30 min após a indução da isquemia modificou os tipos celulares, fazendo com que houvesse diminuição significativa do número de linfócitos. Ainda, em diferentes estudos relatam a participação dos linfócitos na inflamação após IR, não só no intestino (SHIGEMATSU et al., 2002), mas em outros órgãos como fígado (KHANDOGA et al., 2006), cérebro (AHARONI et al., 2003) ou pulmão (DE PERROT et al., 2003). Estudos de Shigematsu et al., (2002) e Cooper et al., (2004) mostraram o papel dos linfócitos na modulação do recrutamento de neutrófilos para o intestino. Ainda, Osman et al., (2009) indicaram que os linfócitos T, linfócitos B e linfócitos derivados do IFN- $\gamma$ contribuem para a maior adesão celular no endotélio vascular, contribuindo assim com a inflamação.

As repercussões da IR intestinal na decorrência da reperfusão passam a afetar não só a área isquêmica, como órgãos distantes, visto que ocorre a disseminação para a circulação de produtos tóxicos, contribuindo para a inflamação sistêmica e até para o desenvolvimento de uma IMOS (THOMAS et al., 2002; VOLLMAR; MENGER, 2011). Assim, se faz importante investigar a forma sistêmica da inflamação gerada pela IR intestinal. Para isso, foram 
realizados, paralelamente, a quantificação do número de leucócitos circulantes no início do experimento (antes da indução da isquemia intestinal) e no final do experimento (após $2 \mathrm{~h}$ de reperfusão intestinal). Nossos resultados mostraram que após a reperfusão houve aumento significativo do número de leucócitos circulantes, o que não foi observado no grupo Sham, sugerindo fortemente que os leucócitos circulantes tenham sido mobilizados, como resultado da IR intestinal. De interesse, o índice (\%) de aumento do número de leucócitos mostrou que em contraste ao do grupo Sham (7,26\%) o grupo submetido à IR intestinal apresentou elevado recrutamento de leucócitos $(59,4 \%)$. Observamos também que o tratamento dos animais com estradiol, 30min após a indução da isquemia intestinal, causou redução do número de leucócitos circulantes, de maneira que o índice de aumento ser de 39,87\%. Todavia o tratamento dos animais com estradiol $24 \mathrm{~h}$ antes da indução da isquemia não alterou o número de leucócitos circulantes como indicado pelo índice de aumento de 63,52\%, o qual foi similar ao dos animais do grupo submetido à IR intestinal.

Vários mecanismos podem justificar o estradiol exercer efeito regulador da mobilização celular. Breithaupt-Faloppa et al., (2014) mostraram a influência do estradiol na mobilização de leucócitos para o pulmão após a IR intestinal. Segundo estes autores o estradiol interfere com a geração de IL-10 e IL-1 $1 \beta$ e expressão de ICAM-1. Além disso, estudos indicam que o estradiol atenua a atividade endotelial reduzindo a adesão de leucócitos nas células endoteliais, por inibir a secreção de quimiocinas pró-inflamatórias (RODRIGUEZ et al., 2002). Análises in vitro de células endoteliais mostraram que o estradiol inibe a expressão de

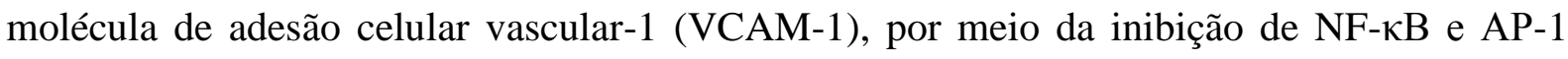
(CAULIN-GLASER et al., 1996). Portanto, considerando o amplo espectro de efeitos do estradiol, nossos dados permitem inferir que uma vez deflagrada a isquemia o estradiol pode exercer efeito terapêutico controlando a mobilização celular para o compartimento circulatório.

Para complementar a avaliação hematológica, determinamos os tipos de leucócitos e o número das plaquetas circulantes. A IR intestinal causou aumento significativo de granulócitos circulantes e em menor escala de monócitos. Além disso, o grupo submetido à IR intestinal apresentou maior número de granulócitos no período de reperfusão intestinal, quando comparado aos animais do grupo Sham. Da mesma forma os leucócitos quantificados no fluido intestinal mostram aumento no número de leucócitos totais, assim como no número de linfócitos, monócitos e granulócitos após a IR intestinal. O que não é observado nos 
leucócitos circulantes, que apresentam apenas aumento do número de granulócitos. Podemos supor que existe algum mecanismo envolvido na mobilização de seus leucócitos, ou que não encontramos diferença nos outros parâmetros por causa da variação individual.

Os animais tratados com estradiol apresentaram aumento do número de granulócitos após a IR intestinal. Contudo não houve diferença significativa quanto ao número de granulócitos em relação ao grupo de animais submetidos à IR intestinal, mas não tratados com estradiol. Esses dados podem sugerir que a mobilização dos granulócitos para o sangue causada pela IR intestinal não é regulada pelo estradiol. Sendo necessários mais estudos, uma vez que estudos indicam que o estradiol é capaz de controlar a migração de células do sangue para os sítios inflamatórios, por meio do controle da expressão de moléculas de adesão, a qual está aumentada na IR intestinal (BREITHAUPT-FALOPPA et al., 2014; OLANDERS et al., 2002). Em relação aos linfócitos e plaquetas circulantes não observamos mudanças significativas após a isquemia ou com os tratamentos com estradiol. Exceto pelo aumento significativo de plaquetas no grupo tratado com estradiol $24 \mathrm{~h}$ antes da isquemia. Nós não investigamos a formação de complexos plaqueta e neutrófilos neste estudo, porém existem dados da literatura que mostram a importância dessa interação para o recrutamento de neutrófilos em diversos modelos de inflamação, incluindo na IR intestinal. Diferentes autores mostraram que neutrófilos para migrarem até o sítio inflamatório formando complexos com plaquetas (KORNERUP et al., 2010; PAGE; PITCHFORD, 2013). Em estudo ainda mais recente Sreeramkumar et al., (2014) demonstraram alterações necessárias para que os neutrófilos modifiquem sua polarização e com isso se complexar com plaquetas e nestas condições ter habilidade para migrar para ou através de um sítio inflamatório.

No geral estes dados permitem inferir que o aumento de leucócitos circulantes dos animais do grupo IR intestinal se deve predominantemente ao aumento de granulócitos na circulação. Considerando os estudos de Arndt et al., (1991), Turnage et al., (1994) e Olanders et al., (2002) durante a IR intestinal nos quais os leucócitos ativados, em especial neutrófilos, são recrutados para o local da injuria, atravessam o endotélio das vênulas pós-capilares atingem o sítio inflamatório então podemos supor que os granulócitos quantificados neste estudo e quantificados por método automático são em especial neutrófilos.

Após análise mais geral do compartimento sistêmico, o compartimento medular também foi investigado. A razão para estes estudos foi estabelecer potencial correlação temporal entre os compartimentos responsáveis pela geração e mobilização de leucócitos após a IR intestinal. 
Nossos dados mostraram que houve mobilização das células presentes na medula óssea e os valores indicaram que a IR intestinal diminuiu o número total de células recuperadas no lavado medular. Esses dados, em conjunto com a análise temporal dos leucócitos circulantes podem sugerir que a IR intestinal mobilizou células da medula óssea para o compartimento sanguíneo, justificando o aumento de leucócitos no fim do experimento. Ainda, podemos sugerir que ocorreu alguma alteração no turnover da geração de células na medula ou eventualmente algum processo de depressão da proliferação de células da medula óssea após a IR intestinal como observado no estudo de Fontes et al., (1994). À semelhança, o trauma seguido de choque hemorrágico, revela mobilização de células da medula óssea e diminuição da capacidade de crescimento dessas células (BADAMI et al., 2007). Vale lembrar que apenas o tratamento preventivo com estradiol, $24 \mathrm{~h}$ antes da indução da isquemia, reverteu a contagem de células da medula óssea para valores similares aos animais controle. Assim é possível que exista regulação do estradiol, sobre o aumento da proliferação celular ou no controle da mobilização das células da medula óssea que se alteraram após a IR intestinal.

$\mathrm{Na}$ medida que neutrófilos correspondem às principais células mobilizadas durante a IR intestinal e, considerando a existência de inflamação em órgãos distantes do local onde ocorreu a isquemia e reperfusão, decidimos investigar se a IR intestinal poderia interferir diretamente com neutrófilos notadamente na sua capacidade de migrar, sem influência de controle endógeno. Nossos dados indicaram que neutrófilos circulantes obtidos após a IR intestinal migraram com maior intensidade espontaneamente. Estes dados sugeriram que neutrófilos circulantes após a IR intestinal tornam-se mais ativados. No geral esses dados justificam o aumento da atividade de MPO no intestino e reforçam que neutrófilos ativos após a IR intestinal são mobilizados para um local distante contribuindo para as consequências inflamatórias da IR intestinal.

Vale lembrar que o tratamento com estradiol reduziu a migração dos neutrófilos, sugerindo sua participação na a ativação dessas células in vivo e observada in vitro. Estudos de Doucet et al., (2010), utilizando modelo de trauma seguido de choque hemorrágico e partindo da premissa de que fêmeas são mais protegidas, investigaram o papel dos receptores de estradiol nesse efeito protetor. De acordo com esses autores os ER- $\beta$ estão envolvidos no controle de uma menor ativação de neutrófilos. Esses dados reforçam a ideia de que o recrutamento/atividade de neutrófilos no intestino poderia ser controlado pelo estradiol. Apesar de elegante, esta percepção não foi investigada para o intestino neste estudo. 
A IR intestinal determina alterações metabólicas que podem causar lesões teciduais. Existem marcadores que quantificam o grau da lesão. Um marcador utilizado para lesão intestinal no modelo de IR intestinal é a fosfatase alcalina (THOMPSON et al., 1990; ZHANG et al., 2011). A quantificação desse marcador confirmou que a IR no intestino elevou sua concentração no soro, sugerindo a existência de lesão tecidual. Por outro lado, o tratamento terapêutico com estradiol (administrado após 30min da indução da isquemia) reduziu os valores de fosfatase alcalina no soro. Esses dados indicam a existência de alguma modulação do estradiol por meio da ativação de receptor de via rápida, em especial o receptor ligado à proteína G30 (GPR-30) (RAZANDI et al., 1999; REVANKAR et al., 2005). Realmente, estudos que excluem os efeitos genômicos (utilizando soro de albumina bovina conjugada com 17- $\beta$ estradiol) indicam que a via rápida é capaz de atenuar a inflamação intestinal, reduzindo marcadores de inflamação, em modelo de trauma seguido de choque hemorrágico (YU et al., 2007a, 2007b). Além do mencionado, existem mecanismos que podem explicar as consequências da ativação da via rápida do estradiol, por exemplo por meio da indução da cascata de sinalização envolvendo a PI3K. Esta família de proteínas regula várias respostas celulares, como proliferação, proteção contra apoptose, geração de superóxidos, migração e adesão celular (CADWALLADER et al., 2002; PURI et al., 2004). Assim, a ativação da PI3K protege órgãos e células contra IR e hipóxia, possivelmente por mecanismos envolvendo a ativação de proteínas da membrana celular como a serina/treonina quinase (Akt) (CAI; SEMENZA, 2004; HISAMOTO et al., 2001; HONDA et al., 2000). Ainda o estradiol ativa a MPAK, a qual em modelos de trauma seguido de choque hemorrágico pode mediar a modulação da atividade da célula de Kupffer e macrófagos esplâncnicos, modulação essa associada à produção de citocinas anti e pró-inflamatórias (SUZUKI et al., 2008).

Além da fosfatase alcalina outro marcador de lesão tecidual é a enzima LDH, a qual é considerada um marcador mais tardio da lesão tecidual. Dados obtidos anteriormente em nosso laboratório e em outros estudos detectaram que a IR intestinal, elevou a atividade sérica de LDH (CAVRIANI et al., 2005; SÖZEN et al., 2011; VAN NOORD et al., 2011). Corroborando com esses dados, as análises deste estudo mostraram que a atividade da enzima LDH no soro de animais submetidos a IR intestinal se elevou. Além disso, nossos dados mostraram efeito protetor do aumento de atividade da LDH pelo tratamento dos animais com estradiol em ambos os protocolos. Vale notar que estudos utilizando o modelo de IR intestinal ou trauma seguido de choque hemorrágico mostraram que níveis séricos de LDH são 
reduzidos em animais tratados com estradiol (BREITHAUPT-FALOPPA et al., 2014; YU et al., 2006b). Desta forma, os dados obtidos neste estudo reforçam a hipótese de que o estradiol possa exercer efeito protetor sistêmico.

Tendo em mente as repercussões sistêmicas da IR intestinal, além dos marcadores de lesão e leucócitos, avaliamos mediadores (citocinas, fatores e quimiocinas) encontrados no soro dos animais submetidos a IR intestinal. De fato, o processo inflamatório sistêmico há um grande contingente de mediadores na corrente sanguínea. Nossos estudos não identificaram a origem (fonte) dos mediadores presentes no soro mas pudemos detectar um vasto número de fatores, citocinas e quimiocinas. Diversos estudos mostraram o importante papel que as citocinas, fatores e quimiocinas têm na inflamação. Souza et al., (2004) mostraram que o tratamento com anticorpos de CINC-1 reduziu a concentração de TNF- $\alpha$ circulante e a MPO nos pulmões e intestino, sugerindo a importância de quimiocinas no influxo de neutrófilos e consequente lesão após IR intestinal. Pope et al., (2010) mostraram que o sistema complemente e toll like receptor-4 (TLR4) medeiam a produção de citocinas, IL-12 e IL-6. Ainda, estudos conduzidos por Lee et al., (2013) sugerem que a IR intestinal induz o intestino delgado a produzir IL-17 levando à lesão intestinal e em órgãos distantes. Ainda, a neutralização ou deficiência dessa citocina acarreta em efeito protetor, local e sistêmico. Liu et al., (2014) mostraram que a inflamação sistêmica gerada pela IR intestinal é atenuada pela inibição da geração de IFN- $\gamma$ pelas células epitelias do íleo.

Nossos dados mostraram aumento significativo de todos os mediadores analisados (IL$1 \beta$, IL-6, IL-10, IL-12p70, IL-17, IFN- $\gamma$, TNF- $\alpha$, MIP-1 $\alpha$, GRO/KC, MCP-1, IP-10, GM-CSF e VEGF) após a indução da IR intestinal. Vários estudos mostraram o envolvimento desses mediadores com a indução da inflamação após a IR intestinal (ATTUWAYBI et al., 2004; CAVRIANI et al., 2004; GROTZ et al., 1999; KNUDSEN, et al., 2011; LI et al., 2010; LIU et al., 2014; POPE et al., 2010; SOUZA et al., 2001, 2003, 2004; YAO et al., 1995;).

As quantificações de TNF- $\alpha$ no líquido intestinal e no soro indicam aumento dessa citocina, sugerindo uma geração intestinal que então eleva as concentrações sistêmicas. Estudos de Frangogiannis et al., (1998) sugerem uma primeira onda de liberação de TNF- $\alpha$ por células residentes, possivelmente mastócitos, atraindo neutrófilos para o tecido, que passa então a produzir mais TNF- $\alpha$ e recrutar mais leucócitos para o local da inflamação. Assim, parece que o TNF- $\alpha$ produzido primeiramente pelo tecido depende do influxo de neutrófilos para promover maior produção de TNF- $\alpha$ e lesão tecidual. Por outro lado, Souza et al., (2001) 
mostraram que o TNF- $\alpha$ circulante não depender da sua produção por neutrófilos, podendo ser gerado pelo fígado ou por células endotelias do intestino. Admite-se que ao invés de liberar TNF- $\alpha$ no tecido estas células liberam a citocina na corrente sanguínea. Estudos também mostraram a relação entre o aumento desta citocina e de citocinas pró-inflamatórias, tais como IL-1 $\beta$, IL-6 ou citocinas anti-inflamatórias, IL-10 (CAVRIANI et al., 2007; SOUZA et al. 2001). Importante lembrar que assim como o TNF- $\alpha$, a IL-10 também apresentou aumento da sua concentração sérica e no líquido intestinal. Ainda, nossos dados revelaram que outros mediadores dosados (GM-CSF, MIP-1, GRO/KC) que apresentaram aumento de quimiotaxia ao recrutarem neutrófilos (DE FILIPPO et al., 2008; SHI et al., 2006). Em específico ao GMCSF também foi atribuída a função de ativação de macrófagos em modelo de IR renal (HUEN et al., 2015) e, ao MIP-1 $\alpha$ também é atribuída a quimiotaxia de monócitos/macrófagos e linfócitos (BAGGIOLINI, 1998).

A IP-10, que segundo nossos dados tem sua concentração aumentada após IR intestinal, é uma quimiocina secretada por neutrófilos, monócitos ou células endoteliais, quando estimuladas por IFN ou lipopolisacarídeo (LPS) (HANCOCK et al., 2001; LUSTER et al., 1987; OHMORI et al., 1990). Além disso, Gangur et al., (1998) mostraram que IP-10 está relacionada com o aumento da liberação de IFN- $\gamma$. Similarmente à IP-10, Nelken et al., (1991) mostraram que o MCP-1 também é uma quimiocina que atrai células T ativadas e ou células NK, sendo também responsável pelo aumento da produção de IL-6 e TNF- $\alpha$ (HASHIZUME et al., 2012).

Entre os mediadores verificamos aumento do VEGF, um fator que pode ser induzido pela hipóxia tecidual. O VEGF exerce diferentes efeitos nas células endoteliais promovendo a formação de novos vasos, o que otimiza a perfusão (LOS et al., 2005; STEIN et al., 1998). Participação na regulação da permeabilidade microvascular e na manutenção da integridade do endotélio na lesão pulmonar decorrente de IR intestinal (MURA et al., 2006).

Também podemos citar a importância de células do epitélio intestinal na produção de citocinas, como a produção de IL-17 pelas células de Paneth, em modelo de IR hepática (PARK et al., 2011). Da mesma forma Cua e Tato, (2010) e Takahashi et al., (2008) também relataram liberação de IL-17 mediada pela produção de TNF- $\alpha$ em modelo de inflamação aguda. Esses dados são indicativos de que a síntese de IL-17 é modulada por outras células, e não apenas por linfócitos, os quais são reconhecidos como a principal fonte de geração dessa citocina (CUA; TATO, 2010). 
Para finalizar nossa investigação do papel do estradiol no controle da inflamação causada pela IR intestinal, analisamos o efeito dos protocolos de tratamento com estradiol. Nossos dados indicaram que o tratamento dos animais com estradiol foi capaz de diminuir a concentração de mediadores de forma não uniforme. Assim alguns mediadores, como IL-1 $\beta$, IL-10 MIP-1 $\alpha$, MCP-1, GRO/KC, IP-10 e VEGF, tiveram redução da sua concentração por ambos os tratamentos. Em contraste a IL-6, GM-CSF e TNF- $\alpha$ diminuíram a concentração apenas com o tratamento de estradiol $24 \mathrm{~h}$ antes da isquemia. Por fim, algumas citocinas não foram moduladas por nenhum dos protocolos de tratamento com estradiol empregados, foram elas: IL-12p70, IL-17 e IFN- $\gamma$. Podemos perceber, portanto que o tratamento preventivo com o estradiol mostrou maior aspecto protetor com relação a produção de mediadores da inflamação.

Estudos realizados por outros autores reforçam o papel protetor do estradiol na produção de mediadores inflamatórios. Mueller et al., (2000) mostraram que o estradiol regula a transcrição gênica de VEGF em cultura de células endometriais. Este fator merece destaque por sua participação na regulação da permeabilidade microvascular e na manutenção da integridade do endotélio na lesão pulmonar decorrente da IR intestinal (MURA et al., 2006). Vale lembrar que o VEGF é até 20.000 vezes mais potente que a histamina em aumentar a permeabilidade microvascular (DVORAK et al., 1995). Assim podemos supor que o mesmo efeito observado no pulmão possa acontecer no intestino, como indicado por nossos dados neste estudo. Estudos de Frazier-Jessen e Kovacs, (1995) revelaram que macrófagos do peritônio de ratos modulam a expressão de MCP-1 e que o estradiol reduz a concentração de MCP-1 no plasma (KOH et al., 2001). Além disso Cox et al., (2015) mostraram que o estradiol em doses baixas foi capaz de reduzir no plasma IL-6, MCP-1 e GRO/KC em lesão à medula espinhal. Ainda, em modelo de trauma seguido de choque hemorrágico a administração de agonista de ER- $\alpha$ ou estradiol reduz a produção de IL-6 e TNF- $\alpha$ em macrófagos, à concentração similar a de animais falsamente operados (SUZUKI et al., 2007c). Da mesma forma apenas o tratamento preventivo mostrou redução de IL-6. Estudos de Kurebayashi et al., (1997) mostraram que realmente o estradiol é capaz de inibir a produção de IL-6, o que foi principalmente atribuído a interferência na expressão do NF- $\kappa$ B. Ainda, Matejuk et al., (2001) observaram inibição da expressão de MIP-1 $\alpha$, MCP-1, TNF- $\alpha$, IP-10 e IFN- $\gamma$ no sistema nervoso central em modelo experimental de encefalomielite autoimune. Podemos supor que o mesmo efeito protetor tenha ocorrido em nossos estudos, contudo diferentemente do estudo acima não houve redução da concentração de IFN- $\gamma$, ou de 
IL-12p70 e IL-17. Vale lembrar que talvez um protocolo de tratamento diferente do utilizado neste estudo poderia resultar na redução destas citocinas.

É interessante notar que ambos protocolos de tratamento com estradiol tiveram efeito na geração de TNF- $\alpha$ encontrado no líquido intestinal, contudo a concentração de TNF- $\alpha$ encontrado no soro foi modificada apenas pelo tratamento preventivo. Por outro lado, a IL-10 encontrada no líquido intestinal não foi modificada pelo tratamento com estradiol. Todavia, ambos os tratamentos dos animais, terapêutico e preventivo, com estradiol reduziram as concentrações desta citocina. Esses estudos sugerem que ao menos no tratamento preventivo, a concentração de IL-10 diminuiu em resposta a redução de TNF- $\alpha$, como indicado por dados de nosso grupo em modelo de IR intestinal. Nesses estudos foi mostrado uma relação direta entre a concentração de TNF- $\alpha$ e IL-10 (CAVRIANI et al., 2007). Ainda, estudos de Squadrito et al., (1997) também relataram que o tratamento com estradiol diminuiu o TNF- $\alpha$ do soro em modelo experimental de IR intestinal. Por fim, estudos de Suzuki et al., (2007d) observaram rápido efeito do tratamento com estradiol na redução no plasma de GM-CSF em modelo experimental de choque. Podemos concluir que o estradiol pode ter efeito protetor na inflamação sistêmica causada por IR intestinal, uma vez que modula a geração de uma variedade de mediadores inflamatórios. É interessante que o momento da administração do estradiol pode modificar a geração destes mediadores de forma diferente e assim modular o curso da resposta inflamatória causada pela IR intestinal.

Tomados em conjunto os dados gerados neste estudo, mostraram que o intestino tem repercussões inflamatórias locais e que após a reperfusão os produtos gerados no local não permanecem represados. Desta forma entendemos o intestino como o "motor" da inflamação e ao terem acesso a demais compartimentos, permite que fatores e mediadores inflamatórios amplifiquem a resposta sistêmica. Além disso, o tratamento dos animais com estradiol mostrou efeito protetor sobre a inflamação intestinal e sistêmica, sendo que cada um dos protocolos utilizados (tratamento terapêutico e preventivo) exerceram funções protetoras distintas e dependentes do momento de sua administração. Assim, o estradiol pode compor alternativa para compreensão dos mecanismos de controle local e sistêmico em eventos isquêmicos que acometem o intestino. Apesar do mencionado, são necessários estudos adicionais para esclarecer os mecanismos envolvidos. 


\section{Conclusões}

- A IR intestinal desencadeia inflamação e alterações funcionais no local (intestino) onde foi desencadeada.

- Reforça-se o conceito de que a inflamação iniciada no intestino se dissemina e pode induzir mudanças na homeostasia em órgãos distantes do local onde foi originada. Esta percepção se baseia nos achados deste estudo que indicam que os eventos celulares e vasculares da inflamação que ocorrem no intestino medeiam a inflamação sistêmica, além de potencialmente interferirem com a atividade funcional do intestino.

- A inflamação sistêmica observada neste modelo pode ser consequência da liberação e absorção, para a cavidade abdominal, do conteúdo de produtos gerados pelo intestino durante a IR intestinal. Dentre eles nossos dados revelaram a presença de IL-10 e TNF$\alpha$, bem como de leucócitos no fluido intestinal os quais uma vez absorvidos contribuiriam para a inflamação sistêmica causada pela IR intestinal e possivelmente para a geração adicional de outros mediadores da inflamação.

- A IR intestinal mobilizou a medula óssea, aumentou o número de leucócitos circulantes e sua capacidade de migração, reforçando a possibilidade de maior recrutamento dessas células para o sítio inflamatório.

- O protocolo de tratamento dos animais com estradiol $30 \mathrm{~min}$ após da indução da isquemia foi eficaz em reduzir os marcadores de lesão tecidual, fosfatase alcalina e LDH, assim como a concentração de IL-1 $\beta$, IL-10, VEGF, MIP-1 $\alpha$, MCP-1, GRO/KC e IP-10 gerados em decorrência da IR intestinal. Todavia o mesmo protocolo de tratamento não alterou a geração de IL-6, IL-12p70, IL-17, IFN- $\gamma$, TNF- $\alpha$ e GM-CSF.

- O protocolo de tratamento dos animais com estradiol $24 \mathrm{~h}$ antes da indução da isquemia foi eficaz em reduzir a atividade de LDH, assim como a concentração de IL-1 $\beta$, IL-10, VEGF, MIP-1 $\alpha$, MCP-1, GRO/KC, IP-10, IL-6, TNF- $\alpha$ e GM-CSF gerados em decorrência da IR intestinal. Todavia o mesmo protocolo de tratamento não alterou a geração fosfatase alcalina, assim como de IL-12p70, IL-17 e IFN- $\gamma$.

Finalmente, os dados obtidos nesse estudo nos permitem concluir que o estradiol modula a inflamação local e sistêmica decorrente da IR intestinal, reforçando portanto a hipótese inicial deste estudo. Neste contexto os resultados sugerem que repercussões locais e sistêmicas decorrentes da IR intestinal podem ser atenuadas pelo estradiol no contexto 
farmacológico de um tratamento terapêutico ou preventivo. Visto que a inflamação no intestino ao ser disseminada, resulta em graves consequências sistêmicas, nossos dados permitem inferir que o estradiol seja uma alternativa de interesse no controle e compreensão dos mecanismos subjacentes à indução da inflamação intestinal após eventos isquêmicos observados no gênero masculino. 


\section{Referências $^{1}$}

AHARONI, R.; KAYHAN, B.; EILAM, R.; SELA, M.; ARNON, R. Glatiramer acetate specific $\mathrm{T}$ cells in the brain express $\mathrm{T}$ helper $2 / 3$ cytokines and brain derived neurotrophic factor in situ. Proc. Natl. Acad. Sci. U S A., v. 100, p. 14157-14162, 2003.

ALEMAYEHU, A.; LOCK, K.R.; COATNEY, R.W.; CHOU, C.C. L-NAME, nitric oxide and jejunal motility, blood flow and oxygen uptake in dogs. Br. J. Pharmacol., v. 111, p. 205-212, 1994.

ANGELE, M.K.; SCHWACHA, M.G.; AYALA A.; CHAUDRY I.H. Effect of gender and sex hormones on immune responses following shock. Shock, v. 14, p. 81-90, 2000.

ANGELE, M.K.; FRANTZ, M.C.; CHAUDRY, I.H. Gender and sex hormone influence the response to trauma and sepsis - potential therapeutic approaches. Clinics, v. 61, p.479-488, 2006.

ANUP, R.; APARNA, V.; PULIMOOD, A.; BALASUBRAMANIAN, K.A. Surgical stress and the small intestine: role of oxygen free radicals. Surgery, v. 125, p. 560-569, 1999.

ARNDT, H.; KUBES, P.; GRANGER, D.N. Involvement of neutrophils in ischemiareperfusion injury in small intestine. Klin. Wochenschr., v. 69, n. 21-23, p. 1056-1060, 1991.

ATTUAWAYBI, B.O.; KOZAR, R.A.; MOORE-OLUFEMI, S.D.; SATO, N.; HASSOUN, H.T.; WEISBRODT, N.W.; MOORE, F.A. Heme oxygenase-1 induction by hemin protects against gut ischemia/reperfusion injury. Am. J. Physiol., v. 118, p. 53-57, 2004.

BADAMI, C.D.; LIVINGSTON, D.H.; SIFRI, Z.C.; CAPUTO, F.J.; BONILLA, L.; MOHR, A.M.; DEITCH, EA. Hematopoietic progenitor cells mobilize to the site of injury after trauma and hemorrhagic shock in rats. J. Trauma, v. 63, n. 3, p. 596-602, 2007.

BAGGIOLINI, M. Chemokines and leukocyte traffic. Nature, v. 392, p. 565-568, 1998. 
BALLABENI, V.; BAROCELlI, E.; BERTONI, S.; IMPICCIATORE, M. Alteration of intestinal motor responsiveness in model of mild mesenteric ischemia/reperfusion in rats. Life Scienc., v. 71, p. 2025-2035, 2002.

BALAKUMAR, P.; PATELIYA, B.; SINGH, G.; SINGH, M. Pathophysiology of Ischemia/Reperfusion-induced Myocardial Injury: What We Have Learned from Preconditioning and Post conditioning? Rania J. Pharmacol. Therap., v. 7, n. 1, p. 115-122, 2008.

BARTELLA, V.; DE MARCO, P.; MALAGUARNERA, R.; BELFIORE, A.; MAGGIOLINI, M. New advances on the functional cross-talk between insulin-like growth factor-I and estrogen signaling in cancer. Cell. Signaling, v. 24, p. 1515-1521, 2012.

BAUER, A.J.; BOECKXSTAENS, G.E. Mechanisms of postoperative ileus. Neurogastroenterol. Motil., v. 16, p. 54-60, 2004.

BEN, D.F.; YU, X.Y.; JI, G.Y.; ZHENG, D.Y.; LV, K.Y.; MA, B.; XIA, Z.F. TLR4 mediates lung injury and inflammation in intestinal ischemia-reperfusion. J. Surg. Res., v. 174, n. 2, p. 326-333, 2012.

BERNIK, T.R.; FRIEDMAN, S.G.; OCHANI, M.; DI RAIMO, R.; SUSARLA, S.; CZURA, C.J.; TRACEY, K.J. Cholinergic antiinflammatory pathway inhibition of tumor necrosis factor during ischemia reperfusion. J. Vasc. Surg., v. 36, p. 1231-1236, 2002.

BERTHIAUME, Y.; LESUR, O.; DAGENAIS, A. Treatment of adult respiratory distress syndrome: plea for rescue therapy of the alveolar epithelium. Thorax, v. 54, p. 150-160, 1999.

BJÖRNSTRÖM, L.; SJÖBERG, M. Mechanisms of estrogen receptor signaling: convergence of genomic and nongenomic actions on target genes. Mol. Endocrinol., v. 19, p. 833-842, 2005.

BOLEY, S.J.; BRANDT, L.J.; SAMMARTANO, R.J. History of mesenteric ischemia - the evolution of a diagnosis and management. Surg. Clin. North Am., v. 77, n. 2, p. 273-288, 1997. 
BONDS, R.S.; MIDORO-HORIUTI, T. Estrogen effects in allergy and asthma. Curr. Opin. Allergy Clin. Immunol., v. 13, n. 1, p. 92-99, 2013.

BOROS, M.; TAKAICHI, S.; MASUDA, J.; NEWLANDS, G.F.; HATANAKA, K. Response of mucosal mast cells to intestinal ischemia-reperfusion injury in the rat. Shock, v. 3, n. 2, p. 125-131, 1995.

BOROVIKOVA, L.V.; IVANOVA, S.; ZHANG, M.; YANG, H.; BOTCHKINA, G.I.; WATKINS,L.R.; WANG, H.; ABUMRAD, N.; EATON, J.W.; TRACEY, K.J. Vagus nerve stimulation attenuates the systemic inflammatory response to endotoxin. Nature, v. 405, p. 458-462, 2000.

BRANISTE, V.; LEVEQUE, M.; BUISSON, BRENAC, C.; BUENO, L.; FIORAMONTI, J.; HOUDEAU, E. Oestradiol decreases colonic permeability through oestrogen receptor $\beta$ mediated up-regulation of occluding and junctional adhesion molecule-A in epithelial cells. $\mathbf{J}$. Physiol., v. 13, p. 3317-3328, 2009.

BREITHAUPT-FALOPPA, A.C.; FANTOZZI, E.T.; ASSIS,-RAMOS, M.M.; VITORETTI, L.B.; COUTO, G.K.; ROSSONI, L.V.; OLIVEIRA-FILHO, R.M.; VARGAFTIG, B.B.; TAVARES-DE-LIMA, W. Protective effect of estradiol on acute lung inflammation induced by a intestinal ischemic insult is dependent on nitric oxide. Shock, v. 40, n. 3, p. 203-209, 2013.

BREITHAUPT-FALOPPA, A.C.; THAÍS-FANTOZZI, E.; ROMERO, D.C.; RODRIGUES, ADA, S.; DE SOUSA, P.T.; LINO-DOS-SANTOS-FRANCO, A.; OLIVEIRA-FILHO, R.M.; VARGAFTIG, B.B.; TAVARES-DE-LIMA, W. Acute lung effect of estradiol on lung inflammation due to intestinal ischemic insult in male rats. Shock, v. 41, n. 3, p. 208-213, 2014.

BYARD, R.W. Acute mesenteric ischemia and unexpected death. J. Forensic Legal Med., v. 19, p. 185-190, 2012.

CADWALLADER, K.A.; CONDLIFFE, A.M.; MCGREGOR, A.; WALKER, T.R.; WHITE, J.F.; STEPHENS, L.R.; CHILVERS, E.R. Regulation of phosphatidylinositol 3-kinase activity and phosphatidylinositol 3,4,5-trisphosphate accumulation by neutrophil priming agents. J. Immunol., v.169, p. 3336-3344, 2002. 
CAI, Z.; SEMENZA, G.L. Phosphatidylinositol-3-kinase signaling is required for erythropoietin-mediated acute protection against myocardial ischemia/reperfusion injury. Circulation, v. 109, p. 2050-2053, 2004.

CALCINA, F.; BAROCELLI, E.; BERTONI, S.; FURUKAWA, O. KAUNITZ, J.; IMPICCIATORE, M.; STERNINI, C. Effect of N-methyl-d-aspartate receptor blockade on neuronal plasticity and gastrointestinal transit delay induced by ischemia/reperfusion in rats. Neuroscience, v. 134, n. 1, p. 39-49, 2005.

CAPLAN, M.S.; HEDLUND, E.; HILL, N.; MACKENDRICk, W. The role of endogenous nitric oxide and platelet-activating factor in hypoxia-induced intestinal injury in rats. Gastroenterology, v. 106, p. 346-352, 1994.

CARDEN, D.L.; GRANGER, D.N. Pathophysiology of ischemia-reperfusion injury. J. Pathol., v. 190, p. 255-266, 2000.

CARUSO, J.M.; DEITCH, E.A.; XU, D.Z.; LU, Q.; DAYAL, S.D. Gut injury and gutinduced lung injury after trauma hemorrhagic shock is gender and estrus cycle specific. $\mathbf{J}$. Trauma, v. 55, p. 531-539, 2003.

CAULIN-GLASER, T.; WATSON, C.A.; PARDI, R.; BENDER, J.R. Effects of 17betaestradiol on cytokine-induced endothelial cell adhesion molecule expression. J. Clin. Invest., v. 98, p. 36-42, 1996.

CAVRIANI, G.; OLIVEIRA-FILHO, R.M.; TREZENA, A.G.; DA SILVA, Z.L.; DOMINGOS, H.V.; DE ARRUDA, M.J.; JANCAR, S.; TAVARES-DE-LIMA, W. Lung microvascular permeability and neutrophil recruitment are differently regulated by nitric oxide in a rat model of intestinal ischemia-reperfusion. Eur. J. Pharmacol., v. 494, p. 241$249,2004$.

CAVRIANI. G.; DOMINGOS, H.V.; SOARES, A.L.; TREZENA, A.G.; LIGEIROOLIVEIRA, A.P.; OLIVEIRA-FILHO, R.M.; SUDO-HAYASHI, L.S.; TAVARES DE LIMA, W. Lymphatic system as a path underlying the spread of lung and gut injury after intestinal ischemia/reperfusion in rats. Shock, v. 23, n. 4, p. 330-6, 2005.

CAVRIANI, G.; DOMINGOS, H.V.; OLIVEIRA-FILHO, R.M.; SUDO-HAYASHI, L.S.; VARGAFTIG, B.B.; DE LIMA, W.T. Lymphatic thoracic duct ligation modulates the serum 
levels of IL-1beta and IL-10 after intestinal ischemia/reperfusion in rats with the involvement of tumor necrosis factor alpha and nitric oxide. Shock, v. 27, n. 2, p. 209-213, 2007.

CERQUEIRA, N.F.; HUSSNI, C.A.; YOSHIDA, W.B. Pathophysiology of mesenteric ischemia/reperfusion: a review. Acta. Cir. Bras., v. 20, n. 4, p. 336-343, 2005.

CHALLIS, J.H.; HARRISSON, F.A.; HEAP, R.B. Metabolic clearance rates and conversion $\mathrm{f}$ estradiol-17-beta in the sheep. The Biochem. J., v. 118, n. 8, p. 11p, 1970.

CHANG, J.X.; CHEN, S.; MA, L.P.; JIANG, L.Y.; CHEN, J.W.; CHANG, R.M.; WEN, L.Q.; WU,W.; JIANG, Z.P; HUANG, Z.T. Functional and morphological changes of the gut barrier during the restitution process after hemorrhagic shock. World J. Gastroent., v. 11, n. 35 , p. 5485-5491, 2005.

CHAUDRY, I.H.; SAMY, T.S.; SCHWACHA, M.G.; WANG, P.; RUE, L.W.; BLAND, K.I. Endocrine targets in experimental shock. J. Trauma, v. 54, p. 118-125, 2003.

CHEN, L.W.; EGAN, L.; LI, Z.W.; GRETEN, F.R.; KAGNOFF, M.F.; KARIN, M. The two faces of IKK and NF-kappa B inhibition: prevention of systemic inflammation but increased local injury following intestinal ischemia-reperfusion. Nat. Med., v. 9, p. 575-581, 2003.

CHEN, J.; YANG, S.; HU, S.; CHOUDHRY, M.A.; BLAND, K.I.; CHAUDRY, I.H. Estrogen prevents intestinal inflammation after trauma-hemorrhage via downregulation of angiotensin II and angiotensin II subtype I receptor. Am. J. Physiol. - Gastroint. Liver Physiol., v. 295, n. 5, p. G1131-G1137, 2008.

COELHO, F.R.; CAVRIANI, G.; SOARES, A.L.; TEIXEIRA, S.A.; ALMEIDA, P.C.; SUDO-HAYASHI, L.S.; MUSCARÁ, M.N.; OLIVEIRA-FILHO, R.M.; VARGAFTIG, B.B.; TAVARES-DE-LIMA, W. Lymphatic-borne IL-1beta and the inducible isoform of nitric oxide synthase trigger the bronchial hyporesponsiveness after intestinal ischemia/reperfusion in rats. Shock, v. 28, p. 694-699, 2007.

COOPER, D.; CHITMAN, K.D.; WILLIAMS, M.C.; GRANGER, D.N.; Time-dependent platelet-vessels wall interaction induced by intestinal ischemia-reperfusion. Am. J. Physiol. Gastrointest. Liver Physiol., v. 284, p. 1027-1033, 2003. 
COOPER, D.; RUSSELl, J.; CHITMAN, K.D.; WILlIAMS, M.C.; WOLF, R.E.; GRANGER, D.N. Leukocyte dependence of platelet adhesion in postcapillary venules. Am. J. Physiol. Heart Circ. Physiol., v. 286, p. H1895-H1900, 2004.

COSTA, M.; BROOKES, S.J.; STEELE, P.A.; GIBBINS, I.; BURCHER, E.; KANDIAH, C.J. Neurochemical classification of myenteric neurons in the guinea-pig ileum. Neuroscience, v. 75, p. 949-967, 1996.

COX, A.A.; VARMA, A.; VERTEGEL, A.; BARRY, J.; BANIK, N. Nanoparticle Estrogen in Rat Spinal Cord Injury Elicits Rapid Anti-inflammatory Effects in Plasma, CSF and Tissue. J. Neurotrauma, 2015. [Epub ahead of print]

CUA, D.J.; TATO, C.M. Innate IL-17-producing cells: the sentinels of the immune system. Nat. Rev. Immunol., v. 10, p. 479-489, 2010.

DE FILIPPO, K.; HENDERSON, R.B.; LASCHINGER, M.; HOGG, N. Neutrophil Chemokines KC and Macrophage-Inflammatory Protein-2 Are Newly Synthesized by Tissue Macrophages Using Distinct TLR Signaling Pathways. J. Immunol., v. 180, p. 4308-4315, 2008.

DELANEY, C.P. Clinical perspectives on postoperative ileus and the effect of opiates. Neurogastroenerol. Motility. v. 16, p. 61-66, 2004.

DE MARCO, R.; LOCATELLI, F.; SUNYER, J.; BURNEY, P. Differences in incidence of reported asthma related to age in men and women. A retrospective analysis of the data of the European Respiratory Health Survey. Am. J. Respir. Crit. Care Med., v. 162, n. 1, p.68-74, 2000.

DE HERTOGH, R.; EKKA, E.; VANDERHEYDEN, I.; HOET, J.J. Metabolic clearance rates and the interconversion factors of estrone and estradiol-17ßin the immature and adult female rat. Endocrinology, v. 87, n. 5, p. 874-880, 1970.

DE PERROT, M.; YOUNG, K.; IMAI, Y.;LIU, M.; WADDELL, T.K.; FISCHER, S.; ZHANG, L.; KESHAVJEE, S. Recipient $\mathrm{T}$ cells mediate reperfusion injury after lung transplantation in the rat. J. Immunol., v. 171p. 4995-5002, 2003. 
DEITCH, E.A. Multiple organ failure - pathophysiology and potential future therapy. Ann. Surg., v. 216, n. 2, p. 117-134, 1992.

DEITCH, E.A. Role of the gut lymphatic system in multiple organ failure. Curr Opin Crit Care, v. 7, p. 92-98, 2001.

DEITCH, E.A.; CHU, H.; XU, D.A.Z. Organ blood flow and the central hemodynamic response are better preserved in female, as opposed to the male rats, after trauma-hemorrhagic shock. J Trauma, v. 65n. 3, p. 566-572, 2008.

DEITCH, E.A.; LIVINGSTON, D.H.; LAVERY, R.F.; MONAGHAN, S.F.; BONGU, A.; MACHIEDO, G.W. Hormonally active women tolerate shock-trauma better than do men: a prospective study of over 4000 trauma patients. Ann. Surg., v. 246, p. 447-453, 2007.

DIEBEL, L.N.; LIBERATI, D.M. Estrogen impairs pulmonary microvascular response to gutderived mediators after shock conditions. J. Trauma, v. 71, p. 656-662, 2011.

DOSSETT, L. A.; SWENSON, B. R.; HEFFERNAN, D.; BONATTI, H.; METZGER, R.; SAWYER, R. G.; MAY, A. K. High levels of endogenous estrogens are associated with death in the critically injured adult. J. Trauma, v. 64, p. 580-585, 2008.

DOUCET, D.; BADAMI, C.; PALANGE, D.; BONITZ, R.P.; LU, Q.; XU, D.Z.; KANNAN, K.B.; COLORADO, I.; FEINMAN, R.; DEITCH, E.A. Estrogen receptor Hormone agonist limit trauma hemorrhage shock-induced gut and lung injury in rats. PLoS One, v. 5, n. 2, p. e9421, 2010.

DVORAK, H.F.; BROWN, L.F.; DETMAR, M.; DVORAK, A. M. Vascular permeability factor/vascular endothelial growth factor, microvascular hyperpermeability, and angiogenesis.Am. J. Pathol., v. 146, p. 1029-1039, 1995.

ELTZCHIG, H.K.; CARMELIET, P. Hypoxia and inflammation. N. Engl. J. Med., v. 364, p. 656-665, 2011.

ELTZSCHIG, H.K.; ECKLE, T. Ischemia and reperfusion — from mechanism to translation. Nat. Med., v. 17, n. 11, p. 1391-1401, 2011. 
FAULDS, M.H.; ZHAO, C.; DAHLMAN-WRIGHT, K.; GUSTAFSSON, J.A. The diversity of sex steroid action: regulation of metabolism by estrogen signaling. J. Endocr., v. 212, p. 3$12,2012$.

FILARDO, E.J.; QUINN, J.A.; BLAND, K.I.; FRACKELTON JR, A.R. Estrogen-induced activation of Erk-1 and Erk-2 requires the G protein-coupled receptor homolog, GPR30, and occurs via trans-activation of the epidermal growth factor receptor through release of HBEGF. Mol. Endocrinol., v. 14, p. 1649-1660, 2000.

FILARDO, E.J. GPER and ER: estrogen receptors with distinct biological roles in breast cancer. Immunol. Endocr. Metab. Agents Med. Chem., v. 11, p. 243-254, 2011.

FISH, E.N. The X-files in immunity: sex-based differences predispose immune responses. Nature Rev. Immunol., v. 8, p. 737-744, 2008.

FONTES, B.; MOORE, F.A.; MOORE, E.E.; KOIKE, K.; KIM, F.; TREW, C.E.; PETERSON, V.M. Gut ischemia induces bone marrow failure and increases rick of infection. J. Surg. Res., v. 57, p. 505-509, 1994.

FRAZIER-JESSEN, M.R.; KOVACS, E.J. Estrogen modulation of JE/monocyte chemoattractant protein-1 mRNA expression in murine macrophages. J. Immunol., v. 154, p. 1838-1845, 1995.

FRANGOGIANNIS， N.G.; LINDSEY,M.L.; MICHAEL， L.H.; YOUKER， K.A.; BRESSLER, R.B.; MENDOZA, L.H.; SPENGLER, R.N.; SMITH, C.W.; ENTMAN, M.L. Resident cardiac mast cells degranulate and release preformed TNF-alpha, initiating the cytokine cascade in experimental canine myocardial ischemia/reperfusion. Circulation, v. 98, p. 699-710, 1998.

FRINK, M.; PAPE, H.C.; VAN GRIENSVEN, M.; KRETTEK, C.; CHAUDRY, I.H.; HILDEBRAND, F. Influence of sex and age on mods and cytokines after multiple injuries. Shock, v. 27, p. 151-156, 2007.

FUKUDA, H.; TSUCHIDA, D.; KODA, K.; MIYAZAKI, M.; PAPPAS, T.N.; TAKAHASHI, T. Impaired gastric motor activity after abdominal surgery in rats. Neurogastroterol. Motil., v. 17, p. 245-250, 2005. 
FUKUMOTO, T.; TAWA, M.; YAMASHITA, N.; OHKITA, M.; MATSUMURA Y. Protective effects of 17beta-estradiol on post-ischemic cardiac dysfunction and norepinephrine overflow through the non-genomic estrogen receptor/nitric oxide-mediated pathway in the rat heart. Eur. J. Pharmacol., v. 699, p. 74-80, 2013.

FURNESS, J.B.; COSTA, M. Types of nerves in the enteric nervous system. Neuroscience, v. 5, n. 1, p. 1-20, 1980.

GANGUR, V.; SIMONS, F. E. R.; HAYGLASS, K. T. Human IP-10 selectively promotes dominance of polyclonally activated and environmental antigen-driven IFN_ over IL-4 responses. FASEB J., v. 12, p. 705, 1998.

GIRN, H. R. S.; AHILATHIRUNAYAGAM, S.; MAVOR, A. I. D.; HOMERVANNIASINKAM, S. Reperfusion Syndrome: Cellular Mechanisms of Microvascular Dysfunction and Potential Therapeutic Strategies. Vasc. Endovasc. Surg., v. 41, n 4, p. 277 293, 2007.

GOLDBERG, R.F.; AUSTEN, W.G.; ZHANG, X.; MUNENE, G.; MOSTAFA, G.; BISWAS, S.; MCCORMACK, M.; EBERLIN, K.R.;NGUYEN, J.T.; TATLIDEDE, H.S.; WARREN, H.S.; NARISAWA, S.; MILLA, J.L.; HODI, R.A. Intestinal alkaline phosphatase is a gut mucosal defense factor maintained by enteral nutrition. Proc. Natl. Acad. Sci. U S A. v. 105, n. 9, p. 3551-3556, 2008.

GOLDBLUM, S.E.; WU, K.M.; JAY, M. Lung myeloperoxidase as a measure of pulmonary leukostasis in rabbits. J. Appl. Physiol., v. 59, n. 6, p. 1978-1985, 1985.

GOTLLICHER, M.; HECK, S.; HERRLICH, P. Transcriptional cross-talk, the second mode of steroid hormone receptor activation. J. Mol. Med., v. 76, p. 480-489, 1998.

GRANGER, D.N. Cell adhesion and migration. II. Leukocyte-endothelial cell adhesion in the digestive system. Am. J. Physiol., v. 273, p. G982-G986, 1997.

GRISHAM, M.B.; BENOIT, J.N.; GRANGER, D.N. Assessment of leukocyte involvement during ischemia and reperfusion of intestine. Methods Enzymol., v. 186, p. 729-742, 1990.

GROOTJANS, J.; HODIN, C.H.; DE HAAN, J.J.; DERIKX, J.P.M.; ROUSCHOP, K.M.A.; VERHEYEN, F.K.; VAN DAM, R.M.; DEJONG, C.H.C.; BUURMAN, W.A.; LENAERTS, 
K. Level of activation of the unfolded protein response correlates with paneth cell apoptosis in human small intestine exposed to ischemia/reperfusion. Gastroente., v.140, p. 529-539, 2011.

GROSSIE, V.B.; WEISBRODT, N.W.; MOORE, F.A.; MOODY, F. Ischemia/Reperfusioninduced disruption of rat small intestine transit is reversed by total enteral nutrition. Nutrition, v. 17, p. 939-943, 2001.

GROSSMAN, C. J. Interactions between the gonadal steroids and the immune system. Science, v. 227, p. 257-61, 1985.

GROTZ, M.R.W.; DEITCH, E.A.; DING, J.; XU, D.Z.; HUANG, Q.H.; REGEL, G. Intestinal cytokine response after gut ischemia: role of gut barrier failure. Ann. Surg., v. 229, n. 4, p. 478-486, 1999.

GUARINI, S.; ALTAVIllA, D.; CAINAZZO, M.M.; GIULIANAI, D.; BIGIANI, A.; MARINI, H.; SQUADRITO, G.; MINUTOLI, L.; BERTOLINI, A.; MARINI, R.; ADAMO, E.B.; VENUTI, F.S.; SQUADRITO, F. Efferent vagal fibre stimulation blunts nuclear factorkappaB activation and protects against hypovolemic hemorrhagic shock. Circulation, v. 107, p. 1189-1194, 2003.

GUIGUÉRE, V. To ERR in the estrogen pathway. Trends Endocrinol. Metabol., v. 13, n. 5, p. $220-225,2002$.

HALLDORSSON, A.O.; KRONON, M.T.; ALLEN, B.S.; RAHMAN, S.; WANG, T. Lowering reperfusion pressure reduces the injury after pulmonary ischemia. Ann. Thorac. Surg., v. 69, n. 1, p. 198-203, 2000.

HANCOCK, W. W.; GAO, W.; CSIZMADIA, V.; FAIA, K.; SHEMMERI, N.; LUSTER, A. D. Donor-derived IP-10 initiates development of acute allograft rejection. J. Exp. Med., v. 193, p. 975, 2001.

HARUKUNI, I.; HURN, P.D.; CRAIN, B.J. Deleterious effect of $\beta$-estradiol in a rat model of transient forebrain ischemia. Brain Res., v. 900, p. 137-142, 2001.

HASHIZUME, M,; MIHARA, M. Blockade of IL-6 and TNF- $\alpha$ inhibited oxLDL-induced production of MCP-1 via scavenger receptor induction. Eur .J. Pharmacol., v. 689, p. 249$254,2012$. 
HASSOUN, H.T.; WEISBRODT, N.W.; MERCER, D.W.; KOZAR, R.A.; MOODY, F.G.; MOORE, F.A. Inducible nitric oxide synthase mediates gut ischemia/reperfusion- induced ileus only after severe insults. J. Surg. Res., v. 97, p. 150-154, 2001.

HEBRA, A.; HONG, J.; MCGOWAN, K.L.; SMITH, C.; MCKERNAN, M.L.; ROSS, A.J. Bacterial translocation in mesenteric ischemia-reperfusion injury: Is dysfunctional motility the link?. J. Ped. Surg., v. 29, n. 2, p. 280-287, 1994.

HILDEBRAND, F.; HUBBARD, W.J.; CHOUDHRY, M.A.; THOBE, B.M.; PAPE, H.C.; CHAUDRY, I.H. Effects of 17beta-estradiol and flutamide on splenic macrophages and splenocytes after trauma-hemorrhage. Cytokine, v. 36, p. 107-114, 2006.

HISAMOTO, K.; OHMICHI, M.; KURACHI, H.; HAYAKAWA, J.; KANDA, Y.; NISHIO, Y.; ADACHI, K.; TASAKA, K.; MIYOSHI, E.; FUJIWARA, N.; TANIGUCHI, N.; MURATA, Y. Estrogen induces the Akt-dependent activation of endothelial nitric-oxide synthase in vascular endothelial cells. J. Biol. Chem., v. 276, p. 3459-3467, 2001.

HO, C.K.; LEE, C.W.; LU, J.; KOH, K.P.; CHAN, C.Y.; HOMER-VANNIASINKAM, S.; CHAO, A.K. New hope for an old cure: a pilot animal study on selective venesection in attenuating the systemic effects of ischemic-reperfusion injury. Ann. Acad. Med. Singapore, v.38, n.7, p. 569-567, 2009.

HOLLAND, J.; CAREY, M.; HUGHES, N.; SWEENEY, K.; BYRNE, P.J.; HEALY, M.; RAVI, N.; REYNOLDS, J.V. Intraoperative splanchnic hypoperfusion, increased intestinal permeability, down-regulation of monocyte class II major histocompatibility complex expression, exaggerated acute phase response, and sepsis. Am. J. Surg. v. 190, n. 3, p.393$400,2005$.

HOLTE, K.; KEHLET, H. Postoperative ileus: a preventable event. Br. J. Surg. v. 87, p. 1480-1493, 2000.

HOMMA, H.; HOY, E.; DA-ZHONG, X.; LU, X.; FEINMAN, R.; DEITCH, E.A. The female intestine is more resistant than the male intestine to gut injury and inflammation when subjected to conditions associated with shock states. Am. J. Physiol. Gastrointest. Liver Physiol., v. 288, p. G466-G472, 2005. 
HONDA, K.; SAWADA, H.; KIHARA, T.; URUSHITANI, M.; NAKAMIZO, T.; AKAIKE, A.; SHIMOHAMA, S. Phosphatidylinositol 3-kinase mediates neuroprotection by estrogen in cultured cortical neurons. J. Neurosci. Res., v. 60, p. 321-327, 2000.

HUEN, S,C.; HUYNH, L.; MARLIER, A.; LEE, Y.; MOECKEL, G.W.; CANTLEY, L.G. GM-CSF Promotes Macrophage Alternative Activation after Renal Ischemia/Reperfusion Injury. J. Am. Soc. Nephrol., v. 26, n. 6, p. 1334-1345, 2015.

JARRAR, D.; WANG, P.; KNÖFERL, M.W.; KUEBLER, J.F.; CIOFFI, W.G.; BLAND, K.I.; CHAUDRY, IH.; Insight into the mechanism by which estradiol improves organ functions after trauma-hemorrhage. Surgery, v. 128, p. 246-52, 2000.

JIANG. W.; KIRKUP, A.J.; GRUNDY, D. Mast cells drive mesenteric afferent signaling during acute intestinal ischemia. J. Physiol., v. 1, n. 589, p. 3867-3882, 2011.

KASER, A.; BLUMBERG, R.S. Endoplasmatic reticulum stress and intestinal inflammation. Mucosal Immunol., v. 3, n. 1, p. 11-16, 2010.

KAWASAKI, T.; CHAUDRY, I.H. The effects of estrogen on various organs: therapeutic approach for sepsis, trauma, and reperfusion injury. Part 1: central nervous system, lung, and heart. J. Anesth., v. 26, n. 6, p. 883-891, 2012a.

KAWASAKI, T.; CHAUDRY, I.H. The effects of estrogen on various organs: therapeutic approach for sepsis, trauma, and reperfusion injury. Part 1: liver, intestine, spleen, and kidney. J. Anesth., v. 26, n. 6, p. 892-899, 2012 b.

KESHAVARZI, Z.; KHAKSARI, M.; GHOLAMREZA, A. The Effects of Female Sexual Hormones and Estrogen Receptor Agonists on The NF- $\kappa B$ p50 and p65 Levels Following TBI in Rat Intestine. J. Neurol. Sci., v.29, p. 576-587, 2012.

KHANDOGA, A.; HANSCHEN, M.; KESSLER, J.S.; KROMBACH, F. CD4+ T cells contribute to postischemic liver injury in mice by interacting with sinusoidal endothelium and platelets. Hepatology, v. 43, p. 306-315, 2006.

KIM, Y.S.; HO, S.B. Intestinal goblet cells and mucins in heath and disease: recent insights and progress. Curr. Gastroenterol. Rep., v. 12, p. 319-330, 2010. 
KINOSHITA, K.; HORI, M.; FUJISAWA, M.; SATO, K.; OHAMA, T.; MOMOTANI, E.; OZAKI, H. Role of TNF-alpha in muscularis inflammation and motility disorder in a TNBSinduced colitis model: clues from TNF-alpha-deficient mice. Neurogastroenterol. Motil., v. 18, n. 7, p. 578-588, 2006.

KOH, K.K.; SON, J,W.; AHN, J.Y.; LEE, S.K.; HWANG, H.Y.; KIM, D.S.; JIN, D.K.; AHN, T.H.; SHIN, E.K. Effect of hormone replacement therapy on nitric oxide bioactivity and monocyte chemoattractant protein-1 levels. Int. J. Cardiol., v. 81, p. 43-50, 2001.

KORNERUP, K.N.; SALMON, G.P.; PITCHFORD, S.C.; LIU, W.L.; PAGE, C.P. Circulating platelet-neutrophil complexes are important for subsequent neutrophil activation and migration. J. Appl. Physiol., v. 109, p. 758-767, 2010.

KNÖFERL, M.W.; JARRAR, D.; ANGELE, M.K.; AYALA, A.; SCHWACHA, M.G.; BLAND, K.I.; CHAUDRY, I.H. 17beta-estradiol normalizes immune responses in ovariectomized females after trauma-hemorrhage. Am. J. Physiol. Cell Physiol., v. 281, p. 1131-1138, 2001.

KNÖFERL, M.W.; ANGELE, M.K.; DIODATO, M.D.; SCHWACHA, M.G.; AYALA, A.; CIOFFI, W.G.; BLAND, K.I.; CHAUDRY, I.H. Female sex hormones regulate macrophage function after trauma-hemorrhage and prevent increased death rate from subsequent sepsis. Ann. Surg., v. 235, p. 105-112, 2002.

KNUDSEN, A.R.; KANNERUP, A.S.; GRONBAEK, H.; ANDERSEN, K.J.; FUNCHJENSEN, P.; FRYSTYK, J.; FLYVBJERG, A.; MORTENSEN, F. Effects of ischemic preand postconditioning on HIF- $1 \alpha$, VEGF and TGF- $\beta$ expression after warm ischemia and reperfusion in the rat live. Comp. Hepatol., v. 10, p. 3, 2011.

KUBES, P. Mast cells and neutrophils in intestinal ischemia/reperfusion. Upda. Inten. Care Emerg. Med. v. 26, p. 102-113, 1996.

KUIPER, G.G.J.M.; CARLSSON, B.; GRANDIEN, K.; ENMARK, E.; HÄGGBLAD, J.; NILSSON, S.; GUSTAFSSON, J.A. Comparison of the ligand binding specificity and transcript tissue distribution of estrogen receptors $\alpha$ and $\beta$. Endocrinology, v. 138, n. 3, p. 863-870, 1997. 
KUREBAYASHI, S.; MIYASHITA, Y.; HIROSE, T.; KASAYAMA, S.; AKIRA, S.; KISHIMOTO, T. Characterization of mechanism of interleukin- 6 gene repression by estrogen receptor. J. Steroid. Biochem. Biol., v. 60, n. 1-2, p. 11-17, 1997.

LA NOUE, J.L.; TURNAGE, R.H.; KADESKY, K.M.; GUICE, K.S.; OLDHAM, K.T.; MYERS, S.I. The effect of intestinal reperfusion on renal function and perfusion. J. Surg. Res., v. 64, p. 19-25, 1996.

LAM, S.K.; HUI, W.M.; CHING, C.K. Peptic ulcer disease: epidemiology, pathogenesis and etiology. In: HAUBRICH, W.S.; SCHAFFNER, F.; BERK, J.E. Bockus Gastroenterology. 5th ed. Philadelphia, PA: WB Saunders, 1994, p. 700-748.

LEE, H.T.; KIM, M.; KIM, J.Y.; BROWN, K.M.; HAM, A.; D’AGATI, V.D.; MORIAKIYAMA, Y. Critical role of interleukin-17A in murine intestinal ischemia-reperfusion injury. Am. J. Physiol. Gastrointest. Liver Physiol., v. 304, p. G12-G25, 2013.

LENAERTS, K.; CEULEMANS, L.J.; HUNDSCHEID, I.H.; GROOTJANS, J.; DEJONG, C.H.; OLDE DAMINK, S.W. New insights in intestinal ischemia-reperfusion injury: implications for intestinal transplantation. Curr. Opin. Organ Transplant., v. 18, n. 3, p. 298-303, 2013.

LI, L.; HUANG, L.; VERGIS, A.L.; YE, H.; BAJWA, A.; NARAYAN, V.; STRIETER, R.M.; ROSIN, D.L.; OKUSA, M.D. IL-17 produced by neutrophils regulates IFN-gammamediated neutrophil migration in mouse kidney ischemia-reperfusion injury. J. Clin. Invest., v. 120 , n. 1, p. 331-342, 2010.

LIGEIRO-DE-OLIVEIRA, A.P.; OLIVEIRA-FILHO, R.M.; da SILVA, Z.L.; BORELLI, P.; TAVARES-DE-LIMA, W. Regulation of allergic lung inflammation in rats: interaction between estradiol and corticosterone. Neuroimmunomodulation, v. 11, n. 1, p. 20-27, 2004.

LIU, L.; TAN, Q.; HU, B.; WU, H.; WANG, C.; TANG, C. Somatostatin Inhibits the Production of Interferon-c by Intestinal Epithelial Cells During Intestinal IschemiaReperfusion in Macaques. Dig. Dis. Sci., v. 59, p. 2423-2432, 2014.

LOOJER-VAN LANGEN, M.; HOTTE, N.; DIELEMAN, L.A.; ALBERT, E.; MULDER, C.; MADSEN, K.L. Estrogen receptor- $\beta$ signaling modulates epithelial barrier function. Am. J. Physiol. Gastrointest. Liver Physiol., v. 300, p. G621-626, 2011. 
LOS, M.; VOEST, E.E.; BOREL, R.I. VEGF as a target of therapy in gastrointestinal oncology. Dig. Surg., v. 22, p. 282-293, 2005.

LUSTER, A. D.; RAVETCH, J. V. Biochemical characterization of a $\gamma$ interferon-inducible cytokine (IP-10). J. Exp. Med., v. 166, p. 1084-1097, 1987.

MA, X.; GAO, F.; CHEN, J.; CHRISTOPHER, T.A.; LOPEZ, B.; OHLSTEIN, E.H.; YUE, T.L. Endothelial protective and antishock effects of a selective estrogen receptor modulator in rats. Am. J. Physiol. Heart Circ. Physiol., v. 280, p. H876-H884, 2001.

MAGGIOLINI, M.; VIVACQUA, A.; FASANELlA, G.; RECCHIA, A.G.; SISCI, D.; PEZZI, V.; MONTANARO, D.; MUSTI, A.M.; PICARD, D.; ANDÒ, S. The G proteincoupled receptor GPR30 mediates c-fos up-regulation by 17beta-estradiol and phytoestrogens in breast cancer cells. J. Biol. Chem., v. 279, n. 26, p. 27008-27016, 2004.

MANTEOLI, G.; BOECKXSTAENS, G.E. The vagal innervation of the gut and immune homeostasis. Recent Advan. Basic Sci., v. 62, p. 1214-1222, 2013.

MAROSTI, A.R.; VINICIUS DA SILVA, M.; PALOMBIT, K.; MENDES, C.E.; TAVARES DE LIMA, W.; CATELUCCI, P. Differential effects of intestinal ischemia and reperfusion in rat enteric neurons and glial cells expressing P2X2 receptors. Histol. Histopathol., v. 30, p. 489-501, 2015.

MASSBERG, S.; MESSMER, K. The nature of ischemia/reperfusion injury. Transplant Proc., v. 39, p. 4217-4223, 1998.

MATEJUK, A.; ADLARD, K.; ZAMORA, A.; SILVERMAN, M.; VANDENBARK, A.A.; OFFNER, H. 17 $\beta$-estradiol inhibits cytokine, chemokine, and chemokine receptor mRNA expression in the central nervous system of female mice with experimental autoimmune encephalomyelitis. J. Neurosc. Res., v. 65, n. 6, p. 529-542, 2001.

MCDERMOTT, W.V.; BROWN, H. Ascites. Annu. Rev. Med., v. 15, p. 79-92, 1964.

MELDRUM, D.R. Estrogen increases protective proteins following trauma and hemorrhage. Am. J. Physiol. Reg. Integ. Corp. Physiol., v. 290, p. 809-811, 2006.

MENDELSOHN, M.E.; KARAS, R.H. Mechanisms of disease: The protective effects of estrogen on the cardiovascular system. N. Engl. J. Med., v. 340, p. 1801-1811, 1999. 
MOEINPOUR, F.; CHOUDHRY, M.A.; TIMARES, L.; SCHWACHA, M.G.; CHAUDRY, I.H. 17 Beta-estradiol normalizes Toll receptor 4, mitogen activated protein kinases and inflammatory responses in epidermal keratinocytes following trauma-hemorrhage. Mol Immunol. v. 44, n. 13, p. 3317-3323, 2007.

MONTALTO, M.C.; HART, M.L.; JORDAN, J.E.; WADA, K.; STAHL, G.L. Role for complement in mediating intestinal nitric oxide synthase-2 and superoxide dismutase expression. Am. J. Physiol. v. 285, p. G197-206, 2003.

MONTEIRO, R.; TEIXEIRA, D.; CALHAU, C. Estrogen signaling in metabolic inflammation. Mediat. Inflamm., 2014. doi: 10.1155/2014/615917.

MOSSER, D.M.; ZHANG, X. Interleukin- 10: new perspectives on an old cytokine. Immunol. Rev., v. 226, p. 205-218, 2008.

MUELLER, M. D.; VIGNE, J. L.; MINCHENKO, A.; LEBOVIC, D. I.; LEITMAN, D. C.; TAYLOR, R. N. Regulation of vascular endothelial growth factor (VEGF) gene transcription by estrogen receptors alpha and beta. Proc. Natl. Acad. Sci. USA, v. 97, p. 10972-10977, 2000.

MURA, M.; HAN, B.; ANDRADE, C. F.; SETH, R.; HWANG, D.; WADDELL, T. K.; KESHAVJEE, S.; LIU, M. The early responses of VEGF and its receptors during acute lung injury: implication of VEGF in alveolar epithelial cell survival.Crit. Care, v.10, p.130, 2006.

NARITA, K.; KUWABARA, Y.; FUJII, Y. Lung Injury After Intestinal IschemiaReperfusion May Be Avoided by the Reduced Absorption of Locally Produced Cytokines. Surg. Today, v. 34, p. 937-942, 2004.

NELKEN, N.A.; COUGHLIN, S.R.; GORDON, D.; WILCOX, J.N. Monocyte chemoattractant protein-1 in human atheromatous plaques. J. Clin. Invest., v. 88, p. 11211127, 1991.

NEWMAN, S.L.; HENSON, J.E.; HENSON, P.M. Phagocitosis of senescente neutrophils by human monocyte-derived macrophages and rabbit inflammatory macrophages. J. Exp. Med., v. 156, p. $430-442,1982$. 
NILSSON, S.; MAKELA, S.; TREUTER, E.; TUJAGUE, M.; THOMSEN, J.; ANDERSSON, G.; ENMARK, E.; PETTERSSON, K.; WARNER, .; GUSTAFSSON, J.A. Mechanism of estrogen action. Physiol. Rev., v. 81, p. 1535-1565, 2001.

OHMORI, Y.; HAMILTON, T. A. A macrophage LPS-inducible early gene encodes the murine homologue of IP-10. Biochem. Biophys. Res. Commun., v. 168, p. 1261-1267, 1990.

OLANDERS K, SUN Z, BÖRJESSON A, DIB M, ANDERSSON E, LASSON A, OHLSSON T, ANDERSSON R: The effect of intestinal ischemia and reperfusion injury on ICAM-1 expression, endothelial barrier function, neutrophil tissue influx, and protease inhibitor levels in rats. Shock, v. 18, n. 1, p. 86-92, 2002.

O'LONE, R.; FRITH, M.C.; KARLSSON, E.K.; HANSEN, U. Genomic targets of nuclear estrogen receptors. Mol. Endocrinol., v. 18, p.1859-1875, 2004.

OLSEN, N. J.; KOVACS, W. J. Gonadal steroids and immunity. Endocr. Rev., v. 17, p. 36984, 1996.

OLSSON, C.; HOLMGREn, S. The control of gut motility. Comp. Biochem. Physiol., v. 128, p. 481-503, 2001.

OLSZYNA, D.P.; PAJKRT, D.; LAUW, F.N.; VAN DEVENTER, S.J.; VAN DER POLL, T. Interleukin 10 inhibits the release of $\mathrm{CC}$ chemokines during human endotoxemia. J. Infect. Dis., v. 181, n. 2, p. 613-620, 2000.

OLSZYNA, D.P.; PAJKRT, D.; LAUW, F.N.; VAN DEVENTER, S.J.; VAN DER POLL, T.; MARCHANT, A.; BRUYNS, C.; VANDENABEELE, P.; DUCARME, M.; GÉRARD, C.; DelvauX, A.; DE GROOTE, D.; ABRAMOWICZ, D.; VELU, T.; GOLDMAN, M. Interleukin-10 controls interferon-gamma and tumor necrosis factor production during experimental endotoxemia. Eur. J. Immunol., v. 24, n. 5, p.1167-1171, 1994.

OSMAN, M.; RUSSEL, J.; GRANGER, D.N. Lymphocyte-derived interferon- mediates ischemia-reperfusion-induced leukocyte and platelet adhesion in intestinal microcirculation. Am. J. Physiol. Gastrointest. Liver Physiol., v. 296, p. G659-G663, 2009.

OZACMAK, V.H.; SAYAN, H.; IGDEM, A.A.; CETIN, A.; OZACMAK, I.D. Attenuation of contractile dysfunction by atorvastatin after intestinal ischemia reperfusion injury in rats. Euro. J. Pharm., v. 562, p. 138-147, 2007. 
PAGE, C.; PITCHFORD, S. Neutrophil and platelet complexes and their relevance to neutrophil recruitment and activation. International. Immunopharmacology, v. 17, p. 1176$1184,2013$.

PALOMBIT, K.; MENDES, C.E.; TAVARES-DE-LIMA, W.; SILVEIRA, M.P.; CASTELUCCI, P. Effects of ischemia and reperfusion on subpopulations of rat enteric neurons expressing the P2X7 receptor. Dig. Dis. Sci., v. 58, n. 12, p. 3429-3439, 2013.

PARKS, D.A.; GRANGER, D.N. Contributions of ischemia and reperfusion to mucosal lesion formation. Am. J. Physiol., v. 250, p. G749-G753, 1986.

PARK, S.W.; KIM, M.; BROWN, K.M.; D’AGATI, V.D.; LEE, H.T. Paneth cellderived IL17A causes multi-organ dysfunction after hepatic ischemia and reperfusion injury. Hepatology, v. 53, p. 1662-1675, 2011.

PAULINO, A.S.; PALOMBIT, K.; CAVRIANI, G.; TAVARES-DE-LIMA, W.; MIZUNO, M.S.; MAROSTI, A.R.; VINICIOS DA SILVA, M.; GIROTTI, P.A.; LIBERTI, E.A.; CASTELUCCI, P. Effects of Ischemia and Reperfusion on P2X2 Receptor Expressing Neurons of the Rat Ileum Enteric Nervous System. Dig. Dis. Sci., v. 56, p. 2262-2275, 2011.

PINES, A.; ECKSTEIN, N.; DOTAN, I.; AYALON, D.; VARON, D.; BARNEA, O.; SHAVIT, G. Effect of estradiol on rat ileum. Gen. Pharmac., v. 35, n. 5, p. 735-736, 1998.

PONTELL, L.; SHARMA, P.; RIVERA, L.R.; THACKER, M.; TAN, Y.H.; BROCK, J.A.; FURNESS, J.B. Damaging effects of ischemia/reperfusion on intestinal muscle. Cell. Tissue Res., v. 343, p. 411-419, 2011.

POPE, M.R.; HOFFMAN, S.M.; TOMLINSON, S.; FLEMING, S.D. Complement regulates TLR4-mediated inflammatory responses during intestinal isquemia reperfusion. Mol. Immunol., v. 48, p. 356-364, 2010.

PROSSNITZ, E.R.; ARTERBURN, J.B.; SMITH, H.O.; OPREA, T.I.; SKLAR, L.A.; HATHAWAY, H.J. Estrogen signaling through the transmembrane G protein-coupled receptor GPR30 Annu. Rev. Physiol., v. 70, p. 165-190, 2008.

PURI, K.D.; DOGGETT, T.A.; DOUANGPANYA, J.; HOU, Y.; TINO, W.T.; WILSON, T.; GRAF, T.; CLAYTON, E.; TURNER, M.; HAYFLICK, J.S.; DIACOVO, T.G. Mechanisms 
and implications of phosphoinositide 3-kinase delta in promoting neutrophil trafficking into inflamed tissue. Blood, v.103, p. 3448-3456, 2004.

QIN, X.; SHETH, S.U.; SHARPE, S.M.; DONG, W.; LU, Q.; XU, D.; DEITCH, E.A. The mucus layer is critical in protecting against ischemia/reperfusion-mediated gut injury and in the restitution of gut barrier function. Shock, v. 35, n. 3, p. 275-281, 2011.

QIU, Y.; YU, M.; YANG, Y.; SHENG, H.; WANG, W.; SUN, L.; CHEN, G.; LIU, Y.; XIAO, W.; YANG, H. Disturbance of intraepithelial lymphocytes in a murine model of acute intestinal ischemia/reperfusion. J. Mol. Histol., v. 45, n. 2, p. 217-227, 2014.

RAJU, R.; CHAUDRY, I.H. Sex steroids/receptor antagonist: their use as adjuncts after trauma-hemorrhage for improving immune/cardiovascular responses and for decreasing mortality from subsequent sepsis. Anesth. Analg., v. 107, p. 159-166, 2008.

RAPPOLD, J.F; COIMBRA, R.; HOYT, D.B.; POTENZA, B.M.; FORTLAGE, D.; HOLBROOK, T.; MINARD, G. Female gender does not protect blunt trauma patients from complications and mortality. J. Trauma, v. 53, p. 436-441, 2002.

RAZANDI, M.; PEDRAM, A.; GREENE, G.L.; LEVIN, E.R. Cell membrane and nuclear estrogen receptors (ERs) originate from a single transcript: studies of ERalpha and ERbeta expressed in Chinese hamster ovary cells. Mol. Endocrinol., v.13, p. 307-319, 1999.

REVANKAR, C.M.; CIMINO, D.F.; SKLAR, L.A.; ARTERBURN, J.B.; PROSSNITZ, E.R. A transmembrane intracellular estrogen receptor mediates rapid cell signaling. Science, v. 307, p. 1625-1630, 2005.

RIFFO-VASQUEZ, Y.; MAN, F.; PAGE, C.P. Doxofylline, a novofylline inhibits lung inflammation induced by lipopolysacharide in the mouse. Pulm. Pharmacol. Ther., v. 27, n. 2, p. 170-178, 2014.

RIBEIRO, M.A.; YOSHIDA, W.B. Reperfusion injury after intestinal ischemia: pathophysiology and experimental models. J. Vasc. Br., v. 4, n. 2, p. 183-194, 2005.

RODRIGUEZ, E.; LOPEZ, R.; PAEZ, A.; MASSO, F.; MONTANO, L.F. 17Beta-estradiol inhibits the adhesion of leukocytes in TNF-alpha stimulated human endothelial cells by 
blocking IL-8 and MCP-1 secretion, but not its transcription. Life Sci., v. 71, p. 2181-2193, 2002.

ROSENBLUM, J.D.; BOYLE, C.M.; SCHWARTZ, L.B. The mesenteric circulation anatomy and physiology. Surg. Clinic. North Am., v. 77, n. 2, p. 289-306, 1997.

RUWART, M.J.; KLEPPER, M.S.; RUSH, B.D. Adrenergic and cholinergic contributions to decreased gastric emptying, small intestinal transit, and colonic transit in the postoperative ileus rat. J. Surg. Res., v. 29, p. 126-134, 1980.

SAGRADA, A.; FARGEAS, M.J.; BUOENO, L. Involvement of alpha-1 and alpha-2 adrenoceptors in the postlaparotomy intestinal motor disturbances in the rat. Gut, v. 28, p. 955-959, 1987.

SALZMAN, A.L. Nitric oxide in the gut. New Horiz., v.3, n.1, p. 33-45, 1995.

SCHABOWSKI, J.; PITERA, J. Peptic ulcer among rural population in a selected region of south-eastern Poland. Ann. Agric. Environ. Med., v. 11, p. 323-327, 2004.

SCHRODER, J.; KAHLKE, V.; BOOK, M.; STUBER, F. Gender differences in sepsis: genetically determined?. Shock, v. 14, p. 307-310, 2000.

SHARAWY, N.; RIBBACK, S.; AL-BANNA, N.; LEHMANN, C.; KERN, H.; WENDT, M., CERNY, V.; DOMBROWSKI, F.; PAVLOVIC, D. Estradiol receptors agonists induced effects in rat intestinal microcirculation during sepsis. Microvasc. Res., v. 85, p. 118-127, 2013.

SHERLOCK, S. Ascites. In: SHERLOCK, S. Diseases of the Liver and Biliary System. 6th ed. Oxford: Blackwell Scientific Publications Ltd, 1981, p. 119-30.

SHETH, S.U.; LU, Q.; TWELKER, K.; SHARPE, S.M.; QIN, X.; REINO, D.C.; LEE, M.A.; XU, D.Z.; DEITCH, E.A. Intestinal mucus layer preservation in female rats attenuates gut injury after trauma-hemorrhagic shock. J. Trauma, v. 68, n. 2, p. 279-288, 2010.

SHI, Y.; LIU, C.H.; ROBERTS, A.I.; DAS, J. XU, G.; REN, G.; ZHANG, Y.; ZHANG, L.; YUAN, Z.R.; TAN, H.S.W.; DAS, G.; DEVADAS, S. Granulocyte-macrophage colonystimulating factor (GM-CSF) and T-cell responses: what we do and don't know. Cell Res., v. 16, p. 126-133, 2006. 
SHIGEMATSU, T.; WOLF, R.E.; GRANGER, D.N. T-lymphocytes modulate the microvascular and inflammatory responses to intestinal ischemia reperfusion. Microcirculation, v. 9, p. 99-109, 2002.

SHIMOMURA, A.; OHAMA, T.; HORI, M.; OZAKI, H. 17 $\beta$-estradiol induces gastrointestinal motility disorder by decreasing CPI-17 phosporylation via changes in Rhofamily G-protein Rnd expression in small intestine. J. Vet. Med. Sci., v. 71, n. 12, p. 15911597, 2009.

SOUSA, A.; RAPOSO, F.; FONSECA, S.; VALENTE, L.; DUARTE, F.; GONÇALVES, M.; TUNA, D.; PAIVA, J.A. Measurement of Cytokines and Adhesion Molecules in the First 72 Hours after Severe Trauma: Association with Severity and Outcome. Dis. Markers, v. 2015, 2015. doi: 10.1155/2015/747036.

SOUZA, D.G.; BERTINI, R.; VIEIRA, A.T.; CUNHA, F.Q.; POOLE, S.; ALLEGRETTI, M.; COLOTTA, F.; TEIXEIRA, M.M. Repertaxin, a novel inhibitor of rat CXCR2 function, inhibits inflammatory responses that follow intestinal ischaemia and reperfusion injury. Br. J. Pharmacol., v. 143, n. 1, p. 132-142, 2004.

SOUZA, D.G.; CASSALI, G.D.; POOLE, S.; TEIXEIRA, M.M. Effects of inhibition of PDE4 and TNF-alpha on local and remote injuries following ischaemia and reperfusion injury. Br. J. Pharmacol., v. 134, p. 985-994, 2001.

SOUZA, D.G.; PINHO, V.; SOARES, A.C.; SHIMIZU, T.; ISHII, S.; TEIXEIRA, M.M. Role of PAF receptors during intestinal ischemia and reperfusion injury. A comparative study between PAF receptor-deficient mice and PAF receptor antagonist trea.tment. Br. J Pharmacol., v. 139, p. 733-740, 2003.

SÖZEN, S.; KISAKÜREK, M.; YILDIZ, F.; GÖNÜLTAS, M.; DINÇEL, A.S. The effects of glutamine on hepatic ischemia reperfusion injury in rats. Hippokratia, v. 15, n. 2, p. 161-166, 2011.

SPERRY, J.L.; NATHENS, A.B.; FRANKEL, H.L.; VANEK, S.L.; MOORE, E.E.; MAIER, R.V.; MINEI, J.P. Inflammation and the Host Response to Injury Investigators. Characterization of the gender dimorphism after injury and hemorrhagic shock: are hormonal differences responsible?. Crit. Care Med., v. 36, p. 1838-1845, 2008. 
SQUADRITO, F.; ALTAVILlA, D.; SQUADRITO, G.; CAMPO, G.M.; ARLOTTA, M.; ARCORACI, V.; MINUTOLI, L.; SAITTA, A.; CAPUTI, A.P. The involvement of tumour necrosis factor-alpha in the protective effects of 17 beta oestradiol in splanchnic ischaemiareperfusion injury. Br. J. Pharmacol., v. 121, n. 8, p. 1782-1788, 1997.

SREERAMKUMAR, V.; ADROVER, J.M.; BALLESTEROS, I.; CUARTERO, M.I.; ROSSAINT, J.; BILBAO, I.; NÁCHER, M.; PITAVAL, C.; RADOVANOVIC, I.; FUKUI, Y.; RODGER, P.; MCEVER, R.P.; FILIPPI, M.D.; LIZASOAIN, I.; RUIZ-CABELLO, J.; ZARBOCK, A.; MORO, M.A. HIDALGO, A. Neutrophils scan for activated platelets to initiate inflammation. Science, v. 346, n. 6214, p. 1234-1238, 2014.

STALLION, A.; KOU, T.D.; LATIFI, S.Q.; MILLER, K.A.; DAHMS, B.B.; DUDGEON, D.L.; LEVINE, A.D. Ischemia/reperfusion: a clinically relevant model of intestinal injury yielding systemic inflammation. J. Ped. Surg., v. 40, p. 470-477, 2005.

STANGL, V.; BAUMANN, G.; STANGL, K. Coronary atherogenic risk factors in women.

Eur. Heart. J., v. 23, p. 1738-1752, 2002.

STRAUB, R.H. The complex role of estrogens in inflammation. Endocr. Rev., v. 28, n. 5, p. 521-574, 2007.

STEIN, I.; ITIN, A.; EINAT, P.; SKALITER, R.; GROSSMAN, Z.; KESHET, E. Translation of vascular endothelial growth factor mRNA by internal ribosome entry: implications for translation under hypoxia. Mol. Cell Biol., v.18, p. 3112-3119, 1998.

SUZUKI, S.; BROWN, C.M.; DELA CRUZ, C.D.; YANG, E.; BRIDWELL, D.A.; WISE, P.M. Timing of estrogen therapy after ovariectomy dictates the efficacy of its neuroprotective and antiinflammatory actions. Proc. Natl. Acad. Sci. U S A., v. 104, n. 14, p. 6013-6018, 2007 d.

SUZUKI, T.; SHIMIZU, T.; YU, H.P.; HSIEH, Y.C.; CHOUDHRY, M.A.; CHAUDRY, I.H. Salutary effects of 17 beta-estradiol on T-cell signaling and cytokine production after traumahemorrhage are mediated primarily via estrogen receptor-alpha. Am. J. Physiol. Cell Physiol., v. 292, p. C2103-C2111, 2007a.

SUZUKI, T.; SHIMIZU, T.; YU, H..; HSIEH, Y.C.; CHOUDHRY, M.A.; SCHWACHA , M.G.; CHAUDRY, I.H. Tissue compartment-specific role of estrogen receptor subtypes in 
immune cell cytokine production following trauma-hemorrhage. J. Applied Physiol., v. 102, n. 1 , p. $163-168,2007 b$.

SUZUKI, T.; SHIMIZU, T.; YU, H..; HSIEH, Y.C.; CHOUDHRY, M.A.; BLAND, K.I..; CHAUDRY, I.H. Estrogen receptor-alpha predominantly mediates the salutary effects of 17beta-estradiol on splenic macrophages following trauma-hemorrhage. Am. J. Physiol. Cell. Physiol., v. 293, p. C978-C984, 2007c.

SUZUKI, T.; YU, H.P.; HSIEH, Y.C.; CHOUDHRY, M.A.; BLAND, K.I.; CHAUDRY, I.H. Estrogen-mediated activation of non-genomic pathway improves macrophages cytokine production following trauma hemorrhage. J. Cell Physiol., v. 214, p. 662-672, 2008.

SUZUKI, Y.; DEITCH, E.A.; MISHIMA, S.; LU, Q.; XU, D.: Inducible nitric oxide synthase gene knockout mice have increased resistance to gut injury and bacterial translocation after an intestinal ischemia-reperfusion injury. Crit. Care Med., v. 28, p. 3692-3696, 2000.

TAKAHASHI, A.; TOMOMASA, T.; KANEKO, H.; WATANABE, T.; TABATA, M.; MORIKAWA, H.; TSUCHIDA, Y.; KUWANO, H. Intestinal motility in an in vivo rat model of intestine ischemia-reperfusion with special reference to the effects of nitric oxide on the motility changes. J. Ped. Gastroenterol. Nutrit. v. 33, p. 283-288, 2001.

TAKAHASHI, N.; VANLAERE, I.; DE, R.R.; CAUWELS, A.; JOOSTEN, L.A.; LUBBERTS, E.; VAN DEN BERG, W.B.; LIBERT, C. IL-17 produced by Paneth cells drives TNF-induced shock. J. Exp. Med., v. 205, p. 1755-1761, 2008.

TAKAYAMA, M.; ISHIBASHI, M.; ISHII, H.; KURAKI, T.; NISHIDA, T.; YOSHIDA, M. Effects of neutrophil elastase inhibitor (ONO-5046) on lung injury after intestinal ischemiareperfusion. J. Appl. Physiol., v. 91, n. 4, p. 1800-1807, 2001.

TARN, A.C.; LAPWORTH, R. Biochemical analysis of ascitic (peritoneal) fluid: what should we measure?. Ann. Clin. Biochem., v. 47, p. 397-407, 2010.

THOMAS, S.; ANUP, R.; SUSAMA, P.; VIDYASAGAR, S.; BALASUBRAMANIAN, K.A. Nitric oxide protects the intestine from the damage induced by laparotomy and gut manipulation. J. Surg. Res., v.99, p. 25-32, 2001. 
THOMAS, S.; KARNIK, S.; BALASUBRAMANIAN, A. Surgical manipulation of the small intestine and its effect on the lung. J. Surg. Res., v. 106, p. 147-156, 2002.

THOMAS, S.; PRABHU, R.; BALASUBRAMANIAN, K. A. Surgical manipulation of the intestine and distant organ damage-protection by oral glutamine supplementation. Surgery, v. 137, p.51-55, 2005.

THOMPSON, J.S.; BRAGG, L.E.; WEST, W.W. Serum enzyme levels during intestinal ischemia. Ann. Surg., v. 211, n. 3, p. 369-373, 1990.

TODO, S.; REYES, J.; FURUKAWA, H.; ABU-EL-MAGD, K.; LEE, R.G.; TZAKIS, A.; RAO, A.S.; STARZL, T.E. Outcome analysis of 71 clinical intestinal transplantations. Ann. Surg., v.222, p. 270-282, 1995.

TÓTH, S.; JONECOVÁ, Z.; VARGA, J.; STAŠKO, P.; KOVAVALČINOVÁ, B.; MARETTA, M.; VESELÁ, J. Mesenteric ischemia-reperfusion injury: Specific impact on different cell population within the jejunal wall in rats. Acta. Histochemica., v. 114, p. 276$284,2012$.

TURNAGE, R.H.; GUICE, K.S.; OLDHAM, K.T. Pulmonary microvascular injury following intestinal reperfusion. New Horiz., v. 2, n. 4, p. 463-475, 1994.

TRACEY KJ. Reflex control of immunity. Nat. Rev. Immunol., v. 9, p. 418-428, 2009.

TRACEY KJ. The inflammatory reflex. Nature, v. 420, p. 853-859, 2002.

VAN DEN HEIJKANT, T.C.; AERTS, B.A.; TEIJINK, J.A.; BUURMAN, W.A.; LUYER, M.D. Challenges in diagnosing mesenteric ischemia. World J. Gastroenterol., v. 19, n. 9, p. 1338-1341, 2013.

VAN NOORD, D.V.; MENSINK, P.B.F.; de KNEGT, R.J.; OUWENDIJK, M.; FRANCKE, J.; van VUUREN, A.J.; HANSEN, B.E.; KUIPERS, E.J. Serum marker and intestinal mucosal injury in chronic gastrointestinal ischemia. Dig. Dis. Sci., v. 56, p. 506-512, 2011.

VAN VEEN, S.Q.; DINANT, S.; VAN VLIET, A.K.; VAN GULIK, T.M. Alkaline phosphatase reduces hepatic and pulmonary injury in liver ischaemia -- reperfusion combined with partial resection. Br. J. Surg., v. 93, n. 4, p. 448-56, 2006. 
VENKOVA, K.; KRIER, J. A nitric oxide and prostaglandin-dependent component of NANC off-contractions in cat colon. Am. J. Physiol., v. 266, p. G40-G47, 1994.

VILLANUEVA, C.; GIULIVI, C. Subcellular and cellular locations of nitric oxide synthase isoforms as determinants of health and disease. Free Radic. Biol. Med., v. 49, n. 3, p. $307-$ $316,2010$.

VITORETTI, L. B. Estudo de mecanismos reguladores da inflamação pulmonar tardia após isquemia e reperfusão intestinal em ratos, 2014.

VOLLMAR, B.; MENGER M. D. Intestinal ischemia/reperfusion: microcirculatory pathology and functional consequences. Arch. Surg., v. 396, p. 13-29, 2011.

WELBORN, C.R.; GOLDMAN, G.; PETERSON, J.S.; VALERI, C.R.; SHEPRO, D.; HECHTMAN, H.B. Pathophysiology of ischemia-reperfusion on injury: central role of the neutrophil. Br. J. Surg., v. 78, p. 651-655, 1991.

WIJNEN, M.H.; VADER, H.L.; ROUMEN, R.M. Multi-antioxidant supplementation does not prevent an increase in gut permeability after lower torso ischemia and reperfusion in humans. Europ. Surg. Res., v. 34, n. 4, p. 300-305, 2002.

WU, H.C.; TUO, B.G.; WU, W.M.; GAO, Y.; XU, Q.Q.; ZHAO, K. Prevalence of peptic ulcer in dyspeptic patients and the influence of age, sex, and Helicobacter pylori infection. Dig. Dis. Sci., v. 53, p. 2650-2656, 2008.

WU, M.C.; BRENNAN, F.H.; LYNCH, J.P.; MANTOVANI, S.; PHIPPS, S.; WETSEL, R.A.; RUITENBERG, M.J.; TAYLOR, S.M.; WOODRUFF, T.M. The receptor for complement component $\mathrm{C} 3 \mathrm{a}$ mediates protection from intestinal ischemia-reperfusion injuries by inhibiting neutrophil mobilization. Proc. Natl. Acad. Sci. U S A., v. 110, n. 23, p. 9439 9444, 2013.

WYERS, M.C.; Acute mesenteric ischemia: diagnostic approach and surgical treatment. Semin. Vasc. Srig., v. 23, n. 1, p. 9-20, 2010.

XIAO,X.; LIU, D.; ZHENG, S.; FU, J; ZHANG, H; CHEN, L. Protective effect of estrogen on intestinal ischemia-reperfusion injury in pubertal rats. J. Ped. Surg., v. 39, n. 12, p. 1828 $1831,2004$. 
XU, D.Z.; ZAETS, S.B.; CHEN, R.; LU, Q.; RAJAN, H.; YANG, X.; ZHANG, J.; FEKETOVA, E.; BOGDAN, N.; DEITCH, E.A.; Cao, Y. Elimination of C5AR prevents intestinal mucosal damage and attenuates neutrophil infiltration in local and remote organs. Shock, v. 31, n. 5, p. 493-499, 2009.

YANG, D.J.; ZHU, Z.X.; FU, H.B.; YAN, R.L.; CHEN, J.; CHENG, Y.J.; CAI, Q.P.; WANG, Q. Hypertonic saline activates CD4+ and CD8+ T-lymphocytes in the small intestine to alleviate intestinal ischemia-reperfusion injury. Eur. Rev. Med. Pharmacol., Sci., v. 18, n. 20, p. 3069-3075, 2014.

YANG, X.; GARTNER, J.; ZHU, L.; WANG, S.; BRUNHAM, R.C. IL-10 gene knockout mice show enhanced Th1-like protective immunity and absent granuloma formation following Chlamydia trachomatis lung infection. J. Immunol., v. 162, n. 2, p. 1010-1017, 1999.

YAO, Y.M.; SHENG, Z.Y.; YU, Y.; TIAN, H.M.; WANG, Y.P.; LU, L.R.; XU, S.H. The potential etiologic role of tumor necrosis factor in mediating multiple organ dysfunction in rats following intestinal ischemia-reperfusion injury. Resuscitation, v. 2, p. 157-168, 1995.

YILMA, A.N.; SINGH, S.R.; FAIRLEY, S.J.; TAHA, M.A.; DENNIS, V.A.. The AntiInflammatory Cytokine, Interleukin-10, Inhibits Inflammatory Mediators in Human Epithelial Cells and Mouse Macrophages Exposed to Live and UV-Inactivated Chlamydia trachomatis. Mediat. Inflamm., v. 2012, 2012. Article ID 520174, doi: 10.1155/2012/520174.

YOSHIDA, W.B. Radicais livres na síndrome da isquemia e reperfusão. Cir. Vasc. Angiol., v. 12, p. 82-95, 1996

YSEBAERT, D.K.; DE GREEF, K.E.; VERCAUTEREN, S,R.; GHIELLI, M.; VERPOOTEN, G.A.; EYSKENS, E.J.; DE BROE, M.E. Identification and kinetics of leukocytes after severe ischaemia/reperfusion renal injury. Nephrol. Dial. Transplant., v. 15, p. $62-74,2000$.

YU, H.P.; HISIEH, Y.C.; SUZUKI, T.; SHIMIZO, T.; CHOUDHRY, M.A.; SCHWACHA, M.G.; CHAUDRY, I.H. Salutary effects of estrogen receptor- $\beta$ agonist on lung injury after trauma-hemorrhage. Am. J. Physiol. Lung Cell. Mol. Physiol., v. 290, p. L1004-L1009, 2006b. 
YU, H.P.; HSIEH, Y.C.; SUZUKI, T.; CHOUDHRY, M.A.; SCHWACHA, M.G.; BLAND, K.I.; CHAUDRY, I.H. The PI3K/Akt pathway mediates the nongenomic cardioprotective effects of estrogen following trauma hemorrhage. Ann. Surg., v. 245, p. 971-977, 2007a.

YU, H.P.; HSIEH, Y.C.; SUZUKI, T.; CHOUDHRY, M.A.; SCHWACHA, M.G.; BLAND, K.I.; CHAUDRY, I.H. Mechanism of the nongenomic effects of estrogen on intestinal myeloperoxidase activity following trauma hemorrhage: up-regulation of the PI-3K/Akt pathway. J. Leukoc. Biol., v. 82, p. 774-780, 2007 b.

YU, H.P.; CHAUDRY, I.H. The role of estrogen and receptor agonist in maintaining organ function after trauma-hemorrage. Shock, v. 31, n. 3, p. 227-237, 2009.

YU, H.P.; SHIMIZU, T.; HSIEH, Y.C.; SUZUKI, T.; CHOUDHRY, M.A.; SCHWACHA, M.G.; CHAUDRY, I.H. Tissue-specific expression of estrogen receptors and their role in the regulation of neutrophil infiltration in various organs following trauma-hemorrhage. $\mathbf{J}$. Leukoc. Biol., v. 79, p. 963-970, 2006a.

ZECKEY, C.; ANDRUSZKOW, H.; NEUNABER, C.; FRINK, M.; SCHIRMER, B. MOMMSEN, P. ; BARKHAUSEN, T.; KRETTEK, C.; HILDEBRAND, F. Protective effects of finasteride on the pulmonary immune response in a combined model of trauma-hemorrhage and polymicrobial sepsis in mice. Cytokine, v. 56, p. 305-311, 2011.

ZHANG, F.X.; MA, B.B.; LIANG, G.Z.; ZHANG, H. Analysis of serum enzyme levels in a rabbit model of acute mesenteric ischemia. Mol. Med. Reports, v. 4, p. 1095-1099, 2011.

ZHAO, H.D.; ZHANG, F.; SHEN, G.; LI, Y.B.; LI, Y.H.; JING, H.R.; MA, L.F.; YAO, J.H.; TIAN, X.F. Sulforaphane protects liver injury induced by intestinal ischemia reperfusion through Nrf2-ARE pathway. World J. Gastroenterol., v. 16, n. 24, p. 3002-3010, 2010.

ZHOU, J.; HUANG, W.Q.; LI, C.; WU, G.Y.; LI, Y.S.; WEN, S.H.; LEI, W.L.; LIU, K.X. Intestinal ischemia/reperfusion enhances microglial activation and induces cerebral injury and memory dysfunction in rats. Crit. Care Med., v. 40, n. 8, p. 2438-2448, 2012.

ZUIDEMA, M.Y.; ZHANG, C. Ischemia/reperfusion injury: the role of immune cells. World J. Cardiol., v. 2, p. 325-332, 2010. 